\title{
Analysis of Aquifer Tests to Determine Hydrologic and Water-Quality Conditions in Stratified-Drift and Riverbed Sediments near a Former Municipal Well, Milford, New Hampshire
}

By THOMAS J. MACK and PHILIP T. HARTE

U.S. Geological Survey

Water-Resources Investigations Report 96-4019

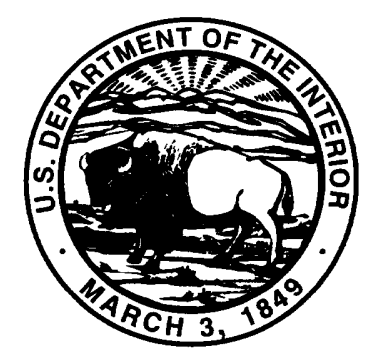




\title{
U.S. DEPARTMENT OF THE INTERIOR BRUCE BABBITT, Secretary
}

\author{
U.S. GEOLOGICAL SURVEY \\ Gordon P. Eaton, Director
}

For additional information write to:

District Chief, New Hampshire/Vermont District

U.S. Geological Survey

Water Resources Division

361 Commerce Way

Pembroke, NH 03275
Copies of this report can be purchased from:

U.S. Geological Survey

Branch of Information Services

Box 25286

Denver, CO 80225-0286 


\section{CONTENTS}

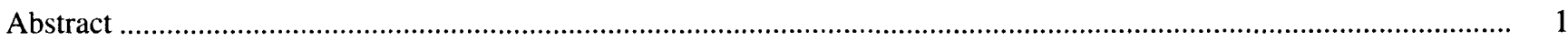

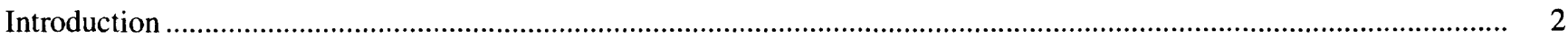

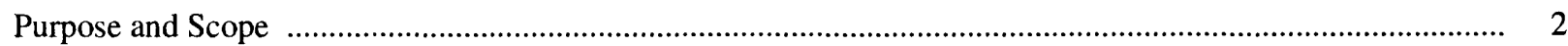

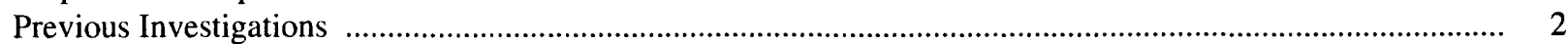

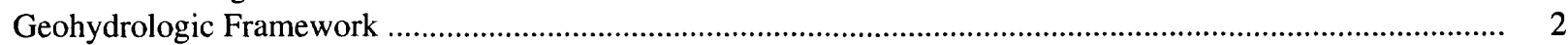

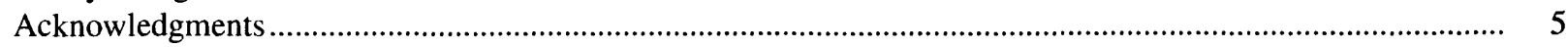

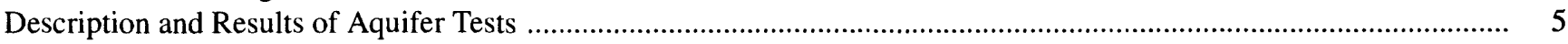

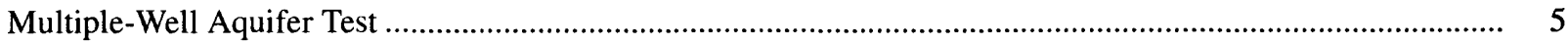

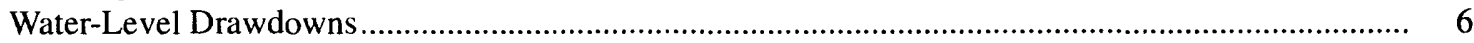

Direction of Ground-Water Flow .................................................................................. 10

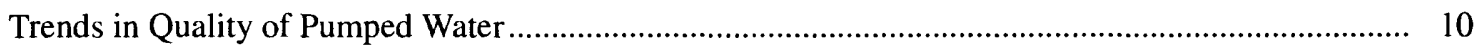

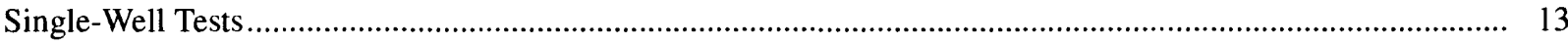

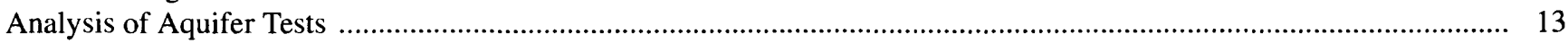

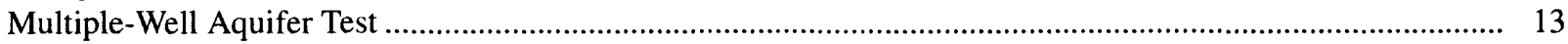

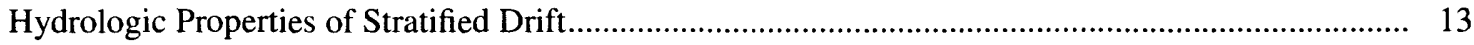

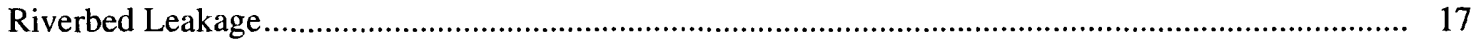

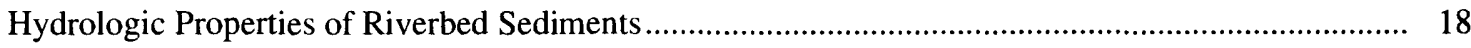

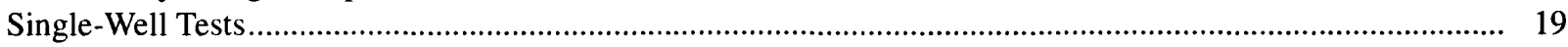

Comparison of Multiple-Well Aquifer and Single-Well Tests ........................................................ 19

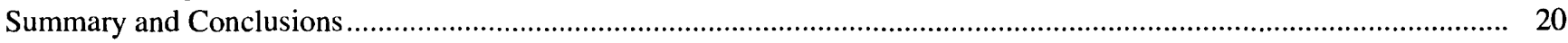

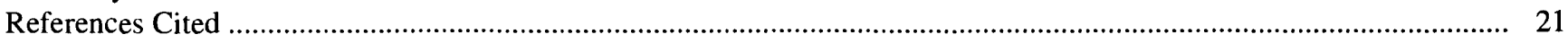

Appendixes

1. Well and piezometer construction data, Milford, New Hampshire............................................................. 23

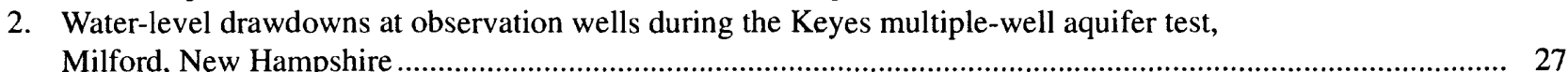

3. Water levels in riverbed piezometers and river stage during the Keyes multiple-well aquifer test,

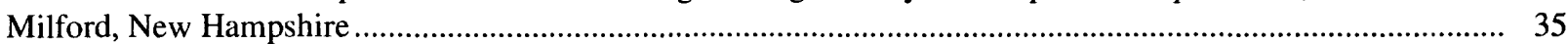

4. Water-level recovery at observation wells after the Keyes multiple-well aquifer test, Milford, New Hampshire.

5. Water-quality constituents measured at the Keyes well during the multiple-well aquifer test,

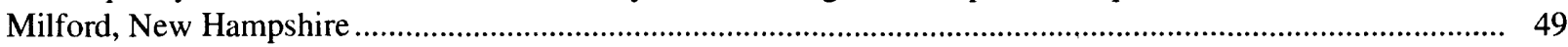

6. Volatile organic chemicals sampled for and detection limits of analysis .................................................. 53

7. Volatile organic chemical analysis of water from the Keyes well during the multiple-well aquifer test,

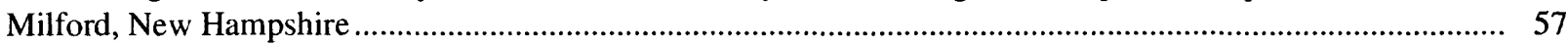

8. Plots of slug test data response at observation wells, Milford, New Hampshire............................................... 61

9. Information used for analysis of multiple-well aquifer test, Milford, New Hampshire .................................... 71

10. Information used for analysis of slug tests, Milford, New Hampshire .......................................................75

\section{FIGURES}

1. Map showing location of Milford-Souhegan glacial-drift aquifer $(A)$ Keyes well field and

$(B)$ location of wells and lines of geologic section.....................................................................
Geologic sections of the Milford-Souhegan glacial-drift aquifer, Milford, New Hampshire:
2. $A-A^{\prime}$
3. $B-B^{\prime}$ 
4-6. Graphs showing:

4. Water-level drawdowns in observation wells during the Keyes multiple-well aquifer test

5. River stage and water levels in riverbed piezometers during the Keyes multiple-well aquifer test at piezometers SK1, SK2, and SK3, and piezometers SP1, SP2, and SP3

6. Normalized drawdown at riverbed piezometers SK1 and SP1 adjusted for changes in river stage

7. Map showing altitude of potentiometric surface and horizontal ground-water-flow directions before and after 720 minutes of pumping at the Keyes well, Milford, New Hampshire

8-10. Graphs showing:

8. Specific conductance, $\mathrm{pH}$, and temperature of water samples from the Keyes well during the multiple-well aquifer test

9. Composite water-level drawdowns in deep observation wells and corresponding type curves during the Keyes multiple-well aquifer test

10. Composite water-level drawdowns in shallow observation wells and corresponding type curves during the Keyes multiple-well aquifer test

\section{TABLES}

1. Summary of aquifer hydrologic properties estimated from the Keyes multiple-well aquifer test,

Milford, New Hampshire

2. Summary of hydrologic conductivity estimates from aquifer and single-well tests, Keyes well,

\section{CONVERSION FACTORS, VERTICAL DATUM, AND ABBREVIATED WATER-QUALIITY UNITS}

\section{CONVERSION FACTORS}

\begin{tabular}{rll}
\hline Multiply & \multicolumn{1}{c}{ By } & To obtain \\
\hline cubic foot per day $\left(\mathrm{ft}^{3} / \mathrm{d}\right)$ & 0.02832 & cubic meter per day \\
cubic foot per second $\left(\mathrm{ft}^{3} / \mathrm{s}\right)$ & 0.02832 & cubic meter per second \\
foot $(\mathrm{ft})$ & 0.3048 & meter \\
gallon per minute $(\mathrm{gal} / \mathrm{min})$ & 0.06309 & liter per second \\
inch (in.) & 25.4 & millimeter \\
mile (mi) & 1.609 & kilometer \\
million gallons per day $(\mathrm{Mgal} / \mathrm{d})$ & 0.04381 & cubic meter per second \\
square foot $\left(\mathrm{ft}^{2}\right)$ & 0.09294 & square meter \\
square foot per day $\left(\mathrm{ft}^{2} / \mathrm{d}\right)$ & 0.0929 & square meter per day \\
square mile $\left(\mathrm{mi}^{2}\right)$ & 2.590 & square kilometer \\
\hline
\end{tabular}

Degrees Celsius $\left({ }^{\circ} \mathrm{C}\right)$ can be converted to degrees Fahrenheit $\left({ }^{\circ} \mathrm{F}\right)$ by use of the following equation:

$$
{ }^{\circ} \mathrm{F}=1.8\left({ }^{\circ} \mathrm{C}\right)+32 \text {. }
$$

\section{VERTICAL DATUM}

Sea level: In this report, "sea level" refers to the National Geodetic Vertical Datum of 1929-a geodetic datum derived from a general adjustment of the first-order level nets of the United States and Canada, formerly called Sea Level Datum of 1929.

\section{ABBREVIATED WATER-QUALITY UNITS}

Chemical properties are expressed in microsiemen per centimeter at 25 degrees Celsius $(\mu \mathrm{S} / \mathrm{cm})$. Chemical concentrations in water are expressed in microgram per liter $(\mu \mathrm{g} / \mathrm{L})$. Microgram per liter is a unit expressing the concentration of chemical constituents in solution as weight (microgram) of solute per unit volume (liter) of water. 


\title{
Analysis of Aquifer Tests to Determine Hydrologic and Water-Quality Conditions in Stratified-Drift and Riverbed Sediments near a Former Municipal-Supply Well, Milford, New Hampshire
}

\author{
By Thomas J. Mack and Philip T. Harte
}

\section{Abstract}

The hydrologic properties of a stratifieddrift aquifer and riverbed at a discontinued municipal well, the Keyes well in Milford, New Hampshire, were estimated from a multiple-well aquifer test and single-well (slug) tests. The Keyes well is screened in the lower parts of a heterogeneous glacial-drift aquifer adjacent to a partially incised river and was removed from service as the result of contamination by volatile organic compounds. This study was conducted in cooperation with the U.S. Environmental Agency, Region I.

Results of a multiple-well aquifer test suggest that the stratified-drift aquifer is heterogeneous and that pumping in the Keyes well field induces inflow from the Souhegan River. Hydrologic properties of the aquifer were analyzed by a method that accounts for partial penetration of the withdrawal and observation wells under unconfined conditions.

Transmissivity was estimated to be about 725 feet squared per day, with an average horizontal hydraulic conductivity of 58 feet per day in the upper part of the glacial aquifer and 10 feet per day in the lower part of the aquifer. A storage coefficient of less than 0.002 was estimated for the lower part of the aquifer. The ratio of vertical to horizontal hydraulic conductivity was estimated to be 0.1 .

Single-well tests, which affect a small aquifer volume, gave comparable estimates of hydraulic conductivity as those estimated by the multiple-well aquifer test. Horizontal hydraulic conductivity estimated from single-well tests was 5.4 to 154 feet per day in the upper part of the aquifer and 1.7 to 105 feet per day in the lower part of the aquifer. The tests showed relatively high hydraulic conductivity west of the Keyes well and low hydraulic conductivity to the south.

Results of temperature trends of pumped water indicate that 25 percent of pumped water is recharged from induced inflow of water from the Souhegan River. Estimated riverbed leakage was 0.16 cubic foot per second as determined by a simple mass balance of pumped-water temperature and temperature contrast between ambient ground water and the river. Riverbed vertical hydraulic conductivity is about 2 feet per day as calculated by use of a simple onedimensional Darcy flow equation for vertical ground-water flow and data on riverbed piezometer drawdowns and estimated riverbed leakage. 


\section{INTRODUCTION}

During 1960-84, the Keyes well was a source of municipal water for the town of Milford, New Hampshire (fig. 1). In 1984, elevated concentrations of 1,2-dichloroethane, 1,1,1-trichloroethane, and tetrachloroethylene were detected in water from the Keyes well, which was subsequently removed from service. The well is at the downgradient end of a $3.3 \mathrm{mi}^{2}$ glacial-drift river valley aquifer, called the Milford-Souhegan aquifer in this report, and is about $40 \mathrm{ft}$ from a partly incised river, the Souhegan River. The 18-inch-diameter well was formerly pumped at a rate of about $0.14 \mathrm{Mgal} / \mathrm{d}$ over a 6 to 8 hour period daily.

The U.S. Geological Survey (USGS), in cooperation with the U.S. Environmental Protection Agency (USEPA), conducted a study from October 1988 to June 1990 of the Milford-Souhegan aquifer to determine the regional ground-water-flow system and provide estimates of the contributing recharge areas to the Keyes well, and to a second discontinued municipal-supply well (the Savage well), about $1.5 \mathrm{mi}$ west of the Keyes well (Harte and Mack, 1992). The study included collection of geohydrologic data and water levels, and measurement of selected waterquality properties from May 1987 to June 1990, and a 7-day multiple-well aquifer test of the Keyes well in October 1988.

Some results of the Keyes well multiple-well aquifer test were examined previously by Harte and Mack (1992); however, the regional nature of the previous study prevented a more comprehensive analysis of the local ground-water-flow system around the Keyes well. As a result, in 1993, the USGS, in cooperation with the USEPA, reexamined the Keyes well multiple-well aquifer test with respect to the local heterogeneity of the aquifer and the interaction of the Souhegan River with the ground-water-flow system.

\section{Purpose and Scope}

The purpose of this report is to present the results of multiple-well aquifer test at the Keyes well and estimations of hydrologic properties of the stratified-drift aquifer and riverbed near the Keyes well. This report includes (1) geologic sections of the aquifer through the Keyes well area, (2) water-level drawdowns from the multiple-well aquifer test, (3) selected water-quality constituents of pumped water measured during the multiple-well aquifer test, and (4) estimates of aquifer and riverbed hydrologic properties. This report also includes results of singlewell tests (slug tests) and grain-size analyses collected at eight observation wells and one riverbed piezometer. The hydrologic properties estimated from the multiplewell aquifer test and single-well tests are compared to improve an understanding of the heterogeneity of the aquifer.

\section{Previous Investigations}

Regional geology and hydrologic properties for glacial deposits in the Milford-Souhegan River valley are provided in Koteff (1970) and Harte and Mack (1992). These studies characterized the deposits near the Keyes well as coarse-grained sand in the upper deposits and progressively fine-grained sand and silt with depth. Sediment, water quality, and ground-waterflow information related to the Keyes well area has been collected by various investigators at a nearby former paint manufacturing site and a gasoline station (Arthur D. Little, Inc., 1994).

\section{Geohydrologic Framework}

The Milford-Souhegan stratified-drift aquifer consists of unconsolidated glacial sediments that fill a pre-glacial valley (fig. 1). These sediments were primarily deposited during the fourth stage of a glacial lake that covered the valley (Koteff, 1970). The spillway for this glacial lake, just south of the Milford town center, was at an altitude of $265 \mathrm{ft}$ above sea level. The spillway outlet and the position of the glacial margin to the north controlled the depositional environment. Till discontinuously underlies stratified drift and consists of dense, poorly sorted sand, silt, and clay. Till thickness ranges from 0 to $13 \mathrm{ft}$ at the Keyes well field (Harte and Mack, 1992). The total saturated thickness of the Milford-Souhegan stratified-drift aquifer ranges from $0 \mathrm{ft}$ at a bedrock outcrop in the Souhegan River about $800 \mathrm{ft}$ east of the Keyes well field, to about $80 \mathrm{ft}$ at about $800 \mathrm{ft}$ west of the Keyes well field. 


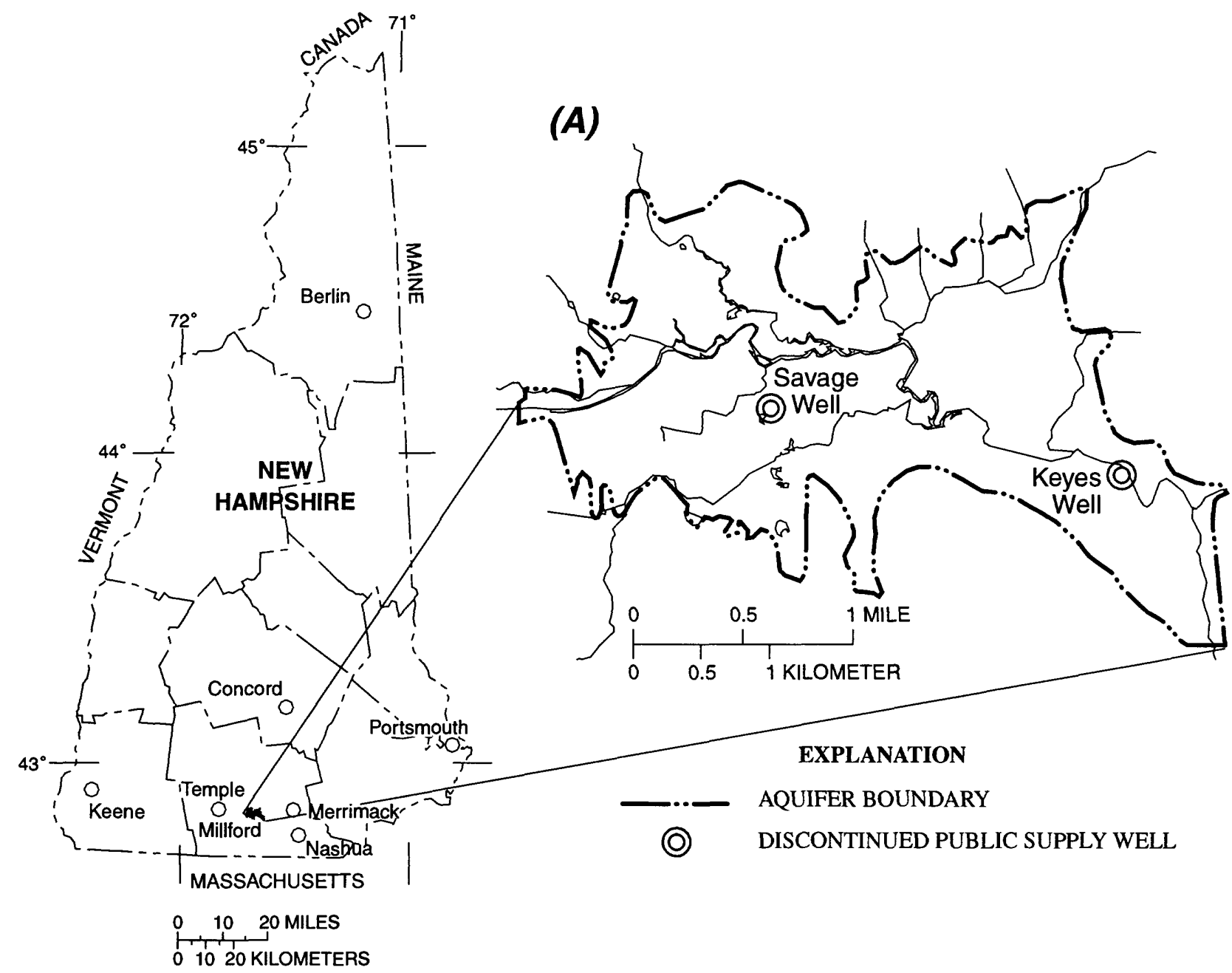

(B)
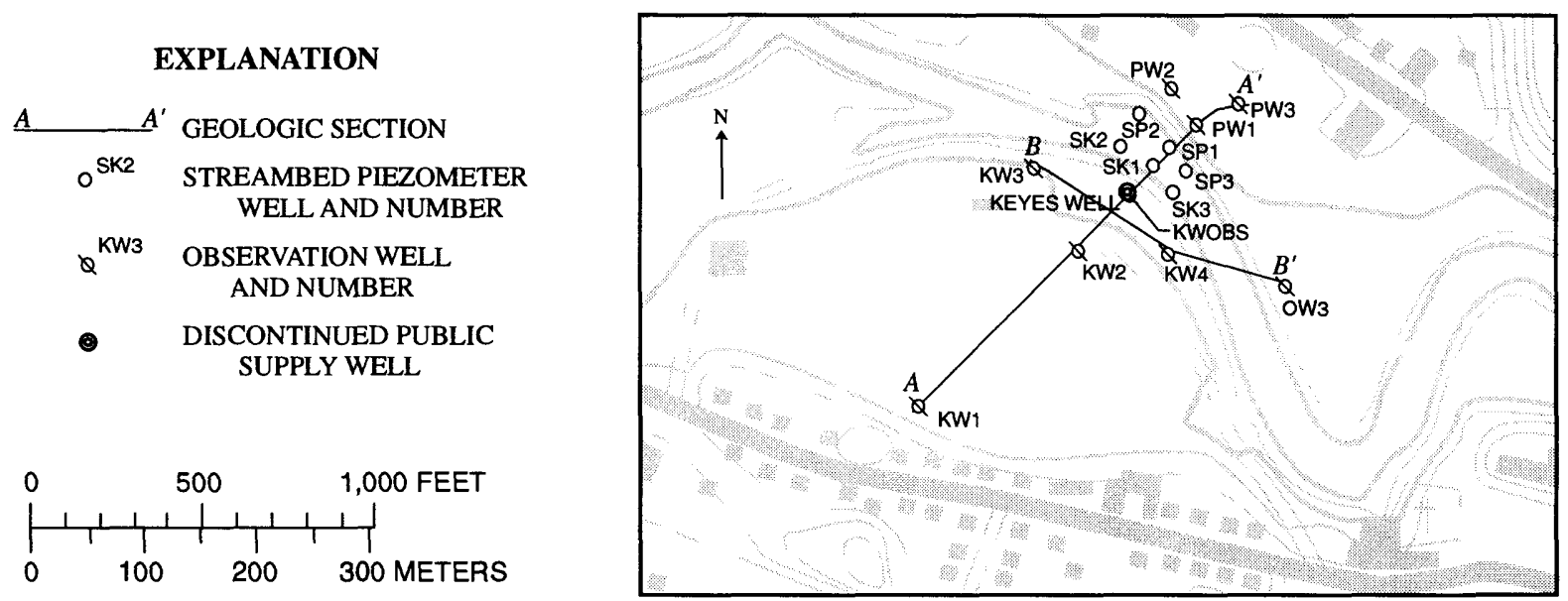

Figure 1. Location of Milford-Souhegan glacial-drift aquifer $(A)$ Keyes well field and $(B)$ location of wells and lines of geologic section. 
The lithology of the aquifer underlying the Keyes well field area is shown in cross section in figures 2 and 3. Lines of section and locations of observation wells and riverbed piezometers are shown in figure 1. Grain-size samples were collected and analyzed during the installation of observation wells at the Keyes well field in September 1988. The distribution of lithologies from test borings indicate a heterogeneous mixture of sands, silts, and gravels. A summary of the vertical distribution of predominant material type is shown in these sections. In general, the sediments of the upper intervals of the aquifer, from land surface to a depth of about $25 \mathrm{ft}$ below land surface, are coarser than sediments at greater depths. Fine-grained sediments are beneath the coarse-grained sediments throughout the area, except at the Keyes well, where coarse sands and gravels are reported in drillers' logs.

The small extent of the basal coarse sands and gravels found at the Keyes well indicate that these sediments represent an esker or ice-channel deposit. This deposit would, therefore, represent an older geologic unit than those found in the valley by Koteff (1970). Eskers and ice-channel deposits tend to be long lenticular-shaped features of limited width. During glacial retreat, a glacial lake formed and fine-grained

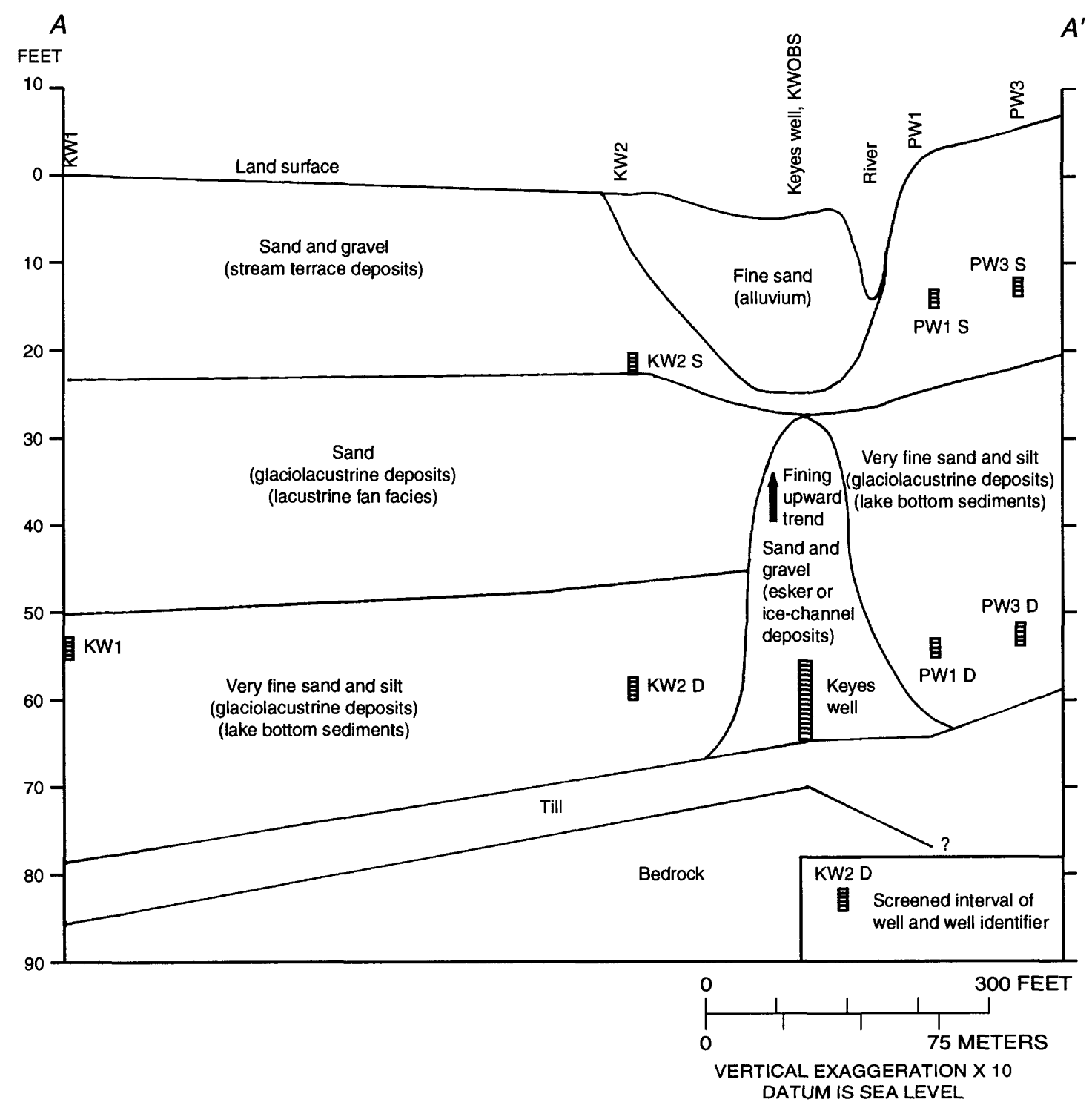

Figure 2. Geologic section $A-A^{\prime}$ of the Milford-Souhegan glacial-drift aquifer, Milford, New Hampshire. (Location of section shown in figure 1.) 


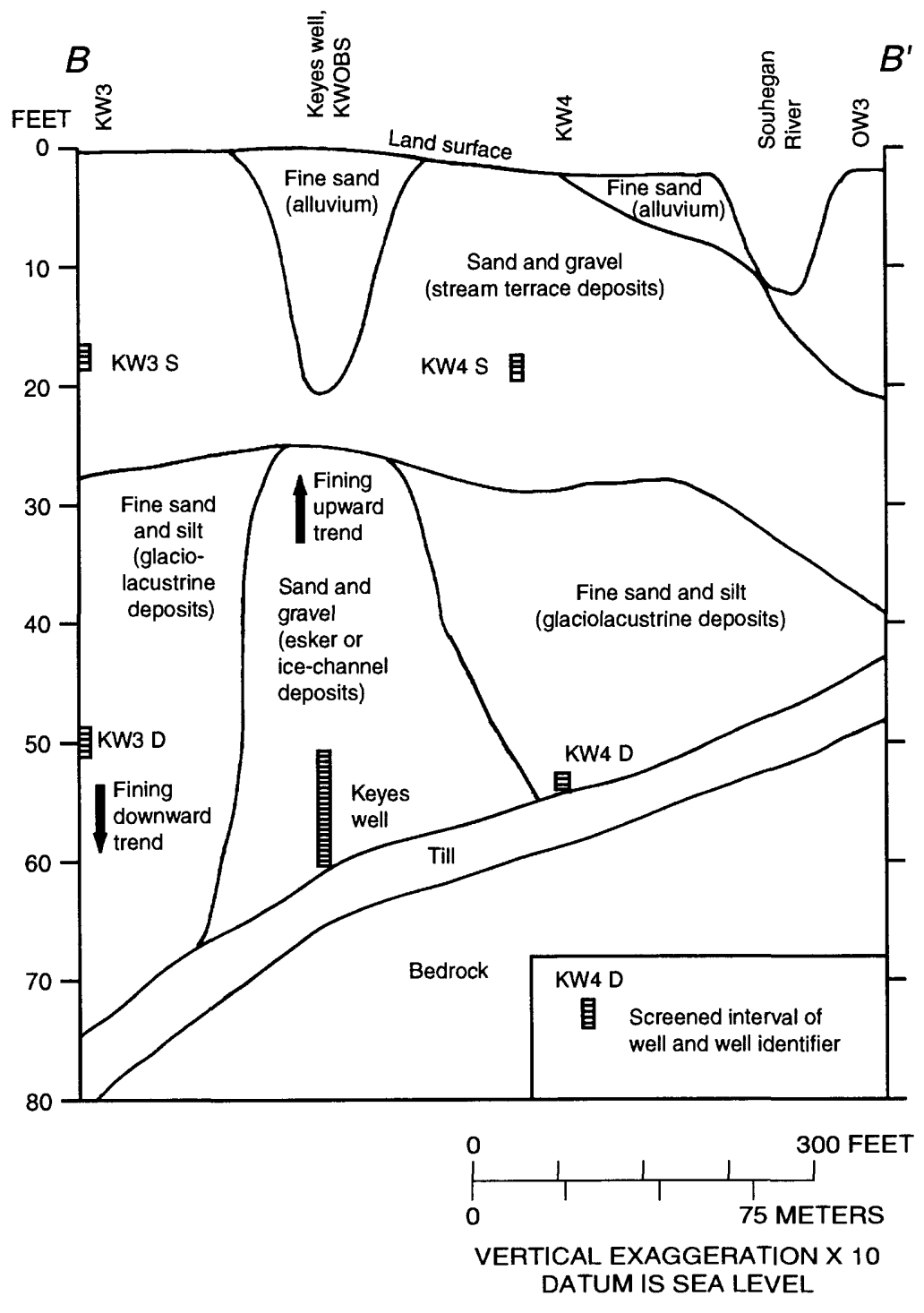

Figure 3. Geologic section $B-B^{\prime}$ of the Milford-Souhegan glacial-drift aquifer, Milford, New Hampshire. (Location of section shown in figure 1.)

lake bottom sediments filled in around the narrow band of sands and gravels. As sediments filled the lake, high energy meltwater caused a coarsening upward sequence to form the upper coarsegrained layer. Reworking of outwash deposits, as a result of meandering streams and deposition and erosion of sediments, left pockets of fine and coarse sands in the upper sediments.

\section{Acknowledgments}

The authors wish to acknowledge officials and employees of the Town of Milford for their cooperation and assistance.

\section{DESCRIPTION AND RESULTS OF AQUIFER TESTS}

Aquifer tests include a multiple observation-well aquifer test, and several single observation-well tests. The multiple observation-well aquifer test measured the response of several observation wells while withdrawing water at the Keyes well. The single-well tests, termed slug tests, measured the response of the aquifer to an instantaneous water-level change at a single observation well.

\section{Multiple-Well Aquifer Test}

A multiple-well aquifer test was conducted at the discontinued Keyes well beginning on October 13, 1988. The well was pumped continuously for 7 days $(10,116 \mathrm{~min})$ at an average rate of $300 \mathrm{gal} / \mathrm{min}$. Prior to the test, 13 observation wells with 2 -foot screens were installed near the Keyes well (fig. 1). Twelve of the wells were grouped in 6 shallow $(\mathrm{KW} 2 \mathrm{~s}, \mathrm{KW} 3 \mathrm{~s}, \mathrm{KW} 4 \mathrm{~s}$, PW1s, PW2s, Pw3s) and deep (KW2d, KW3d, KW4d, PW1d, PW2d, Pw3d) well pairs. Shallow wells were screened just below the water table, at 20 to $25 \mathrm{ft}$ below land surface. Deep wells were screened at the midpoint of the depth of the Keyes well screen, about 50 to $60 \mathrm{ft}$ below land surface. Water levels also were measured at two pre-existing wells (OW3, KW1). Six riverbed piezometers (SK1, SK2, SK3, SP1, SP2, SP3) were installed just below the river bottom in the Souhegan River to examine water levels and hydrologic properties at the river-aquifer boundaries.

Distances from the Keyes well, screened interval below the water table, and other information for observation wells and piezometers are summarized in appendix 1. Water-level drawdowns at six observation wells during the multiplewell aquifer test are listed in appendix 2 , 
and the water levels in six streambed piezometers and river stage are listed in appendix 3. Water-level recoveries at 10 observation wells after pumping ceased are listed in appendix 4 . Specific conductance, $\mathrm{pH}$, and temperature of the water pumped from the Keyes well were measured during the multiple-well aquifer test to determine sources of withdrawn water and are listed in appendix 5. Water samples collected during the multiple-well aquifer test were analyzed for volatile organic compounds (VOC's) (appendix 6), by the New Hampshire Department of Environmental Services (Patricia Hannon, written commun., 1988), and the results are listed in appendix 7.

Hydrologic conditions from natural stresses before and during the multiple-well aquifer test were relatively stable. Before the multiple-well aquifer test, on October 5-13, 1988 (Harte and Mack, 1992, appendix 3 ), water-table changes ranged from 0.05 to $0.21 \mathrm{ft}$ in shallow wells (KW2s, KW3s, KW4s, PW1s, PW2s, and PW3s) near the Keyes well. Water-table levels measured at four wells outside the influence of pumping, before and during the multiple-well aquifer test, fluctuated by less than $0.5 \mathrm{ft}$ with no pattern of rise or decline (Harte and Mack, 1992, appendix 3, well numbers 123, 150, 151, and 152). At well $\mathrm{KW} 1,870 \mathrm{ft}$ from the Keyes well (fig. 1), the water level declined $0.15 \mathrm{ft}$ during the multiple-well aquifer test, and at well OW3, $440 \mathrm{ft}$ from the Keyes well and on the bank of the river, the water level was unchanged. Trace precipitation of 0.03 in. occurred on the sixth day of the test. On the seventh day of the test, water levels rose several tenths of a foot from a corresponding rise in the river stage. The rise in river stage was the result of precipitation in the headwaters of the Souhegan River drainage basin upstream from the Keyes well.

\section{Water-Level Drawdowns}

Water-level drawdowns from observation-well pairs are presented in figure 4. Plots of the deep-well data show smooth drawdown curves (fig. 4) with the exception of well PW2d where measurement difficulties hindered data collection. Plots of the shallow well (KW2s, KW3s, KW4s, PW 1s, PW2s, and PW3s) data (fig. 4) are not as smooth as those for the deep wells (KW2d, KW3d, KW4d, PW1d, PW2d, and PW3d), because fewer data were collected at the shallow wells. The drawdown curves indicate an intermediate time, generally 50 to $2,000 \mathrm{~min}$, of stabilized drawdown in the deep wells in response to the effects of either a leaky river boundary or delayed gravity drainage. Drawdowns in deep wells show a "late time" increase, but a rise in river stage at about 7,000 min effectively eliminates the remainder of the test from analysis (fig. 4). Precipitation in the headwaters of the Souhegan River drainage basin, at about $1,500 \mathrm{~min}$, resulted in a rise in river stage as shown in the drawdown curve for shallow well KW3s, adjacent to the river (fig. 1). The effect of precipitation is small on other drawdown curves (fig. 4). Drawdowns in shallow wells were approaching the drawdowns in the deep wells near the end of the test. With favorable weather conditions and prolonged pumping, drawdowns in the upper part of the aquifer may have approached drawdowns in the lower part of the aquifer.

Water levels were measured in six riverbed piezometers, three on each side of the Souhegan River, during the multiple-well aquifer test (appendix 3). Water levels in the piezometers on the southwest bank of the Souhegan River adjacent to the Keyes well (SK1, SK2, SK3) and river stage are shown in figure $5 \mathrm{~A}$. Water levels in piezometers on the northeast bank of the Souhegan River (SP1, SP2, SP3) and river stage are shown in figure $5 B$. Water-level

measurements in the piezometers were from the top of each piezometer casing. River stage was measured from the top of piezometer SK1 (fig. 1). Before pumping, the water levels in the piezometers were slightly higher than the river stage. The water levels in piezometers fluctuate with changes in river stage. Early in the multiple-well aquifer test, at times less than $200 \mathrm{~min}$, the river stage is constant and water-level drawdowns at the piezometers are readily apparent. Between 200 and $500 \mathrm{~min}$, the river stage declined slightly, which increases drawdown in the piezometers. Later in the test, greater fluctuations in river stage of up to $0.5 \mathrm{ft}$ and centered at $1,500 \mathrm{~min}$, result in fluctuations in the riverbed piezometer water levels.

Water levels at SK1 and SP1 were adjusted for changes in river stage to remove river-stage changes on piezometer drawdown. Stage change was added to or subtracted from the piezometer drawdown to adjust the piezometer drawdown (fig. 6). Drawdowns at SK1 and SPl were essentially the same early in the multiplewell aquifer test (at times less than $200 \mathrm{~min}$ ) and were similar throughout the remainder of the multiple-well aquifer test. The maximum drawdown at piezometers SK1 and SP1 was $0.2 \mathrm{ft}$ at about $6,000 \mathrm{~min}$. 

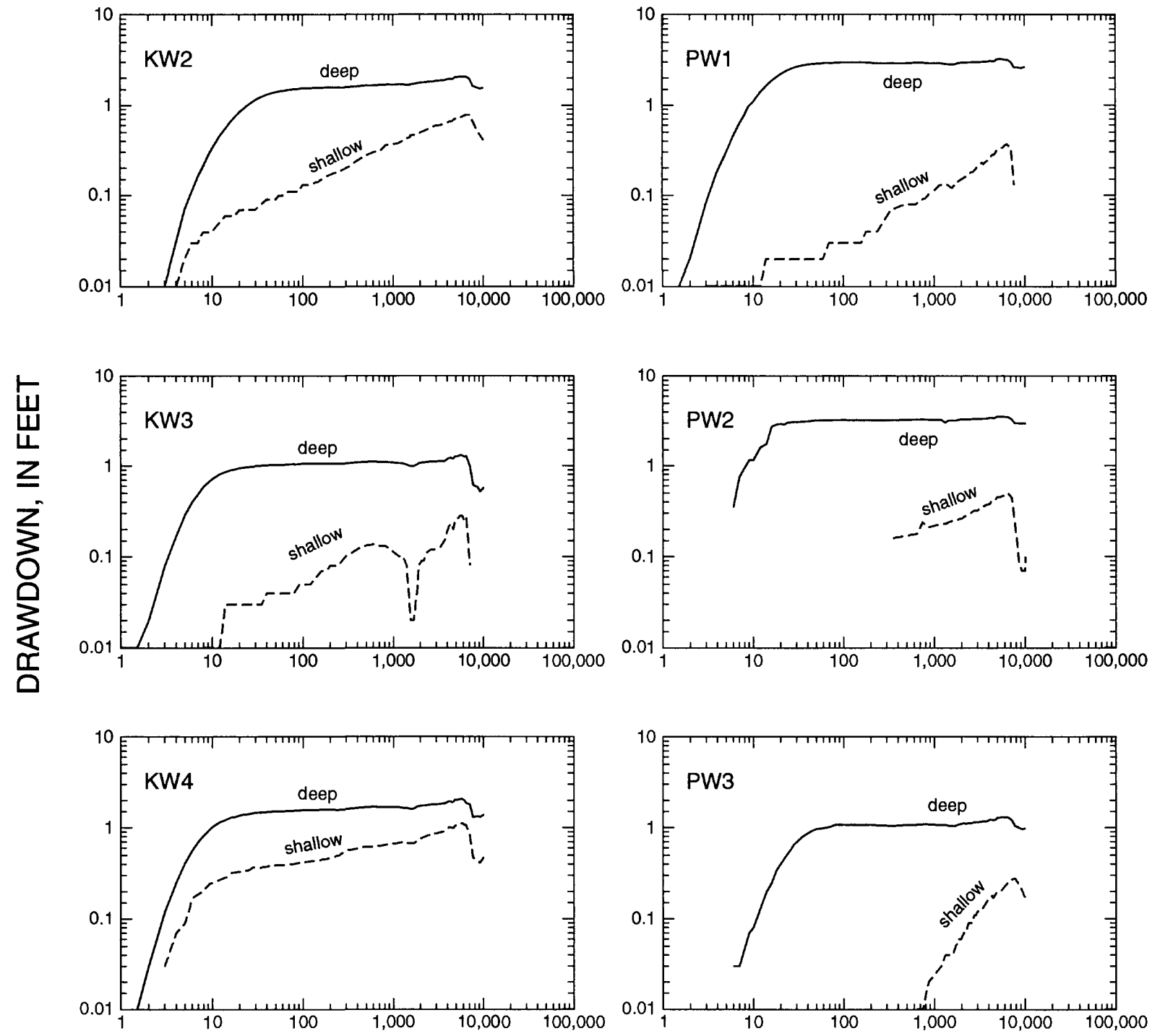

TIME FROM START OF AQUIFER TEST, IN MINUTES

Figure 4. Water-level drawdowns in observation wells during the Keyes multiple-well aquifer test.

In general, water-level drawdowns at the shallow and deep observation wells indicate that the multiplewell aquifer test is affected by a leaky river boundary, delayed gravity drainage, and the fact that the aquifer and river leakage are heterogeneous. Delayed-gravity drainage at the water table is slight as a result of riverwater leakage and the short duration of the test.

Drawdowns from wells across the river from the Keyes well (PW1d, PW2d, and PW3d) show delays in initial drawdown responses that may be attributed to higher aquifer storage to the north of the Keyes well. The delayed response to the north also may be the result of river leakage. Greater drawdowns in deep wells PW1d and PW2d, than those at other deep wells, suggest low transmissivity in that area of the aquifer. Greater drawdowns in shallow wells KW4s and KW2s, than at other shallow wells, suggest low transmissivity in the upper aquifer in that area and less leakage. Induced infiltration may be greatest near well $\mathrm{KW} 3 \mathrm{~s}$ because drawdown is lower at well KW3s than at other watertable wells and this well shows a significant response to a rise in the river stage suggesting good hydraulic connection with the river. 


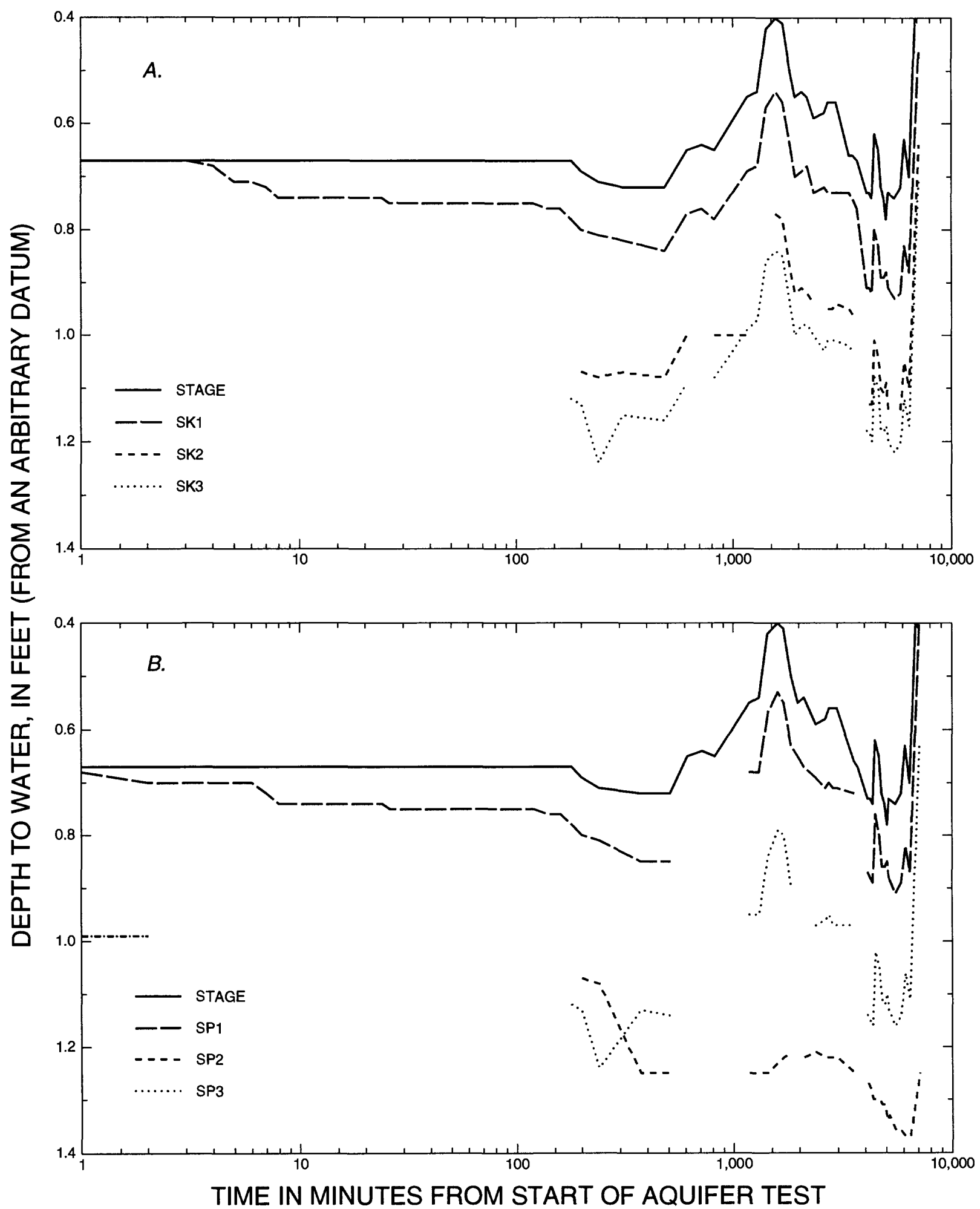

Figure 5. River stage and water levels in riverbed piezometers during the Keyes multiple-well aquifer test at (A) piezometers SK1, SK2, and SK3, and (B) piezometers SP1, SP2, and SP3. 


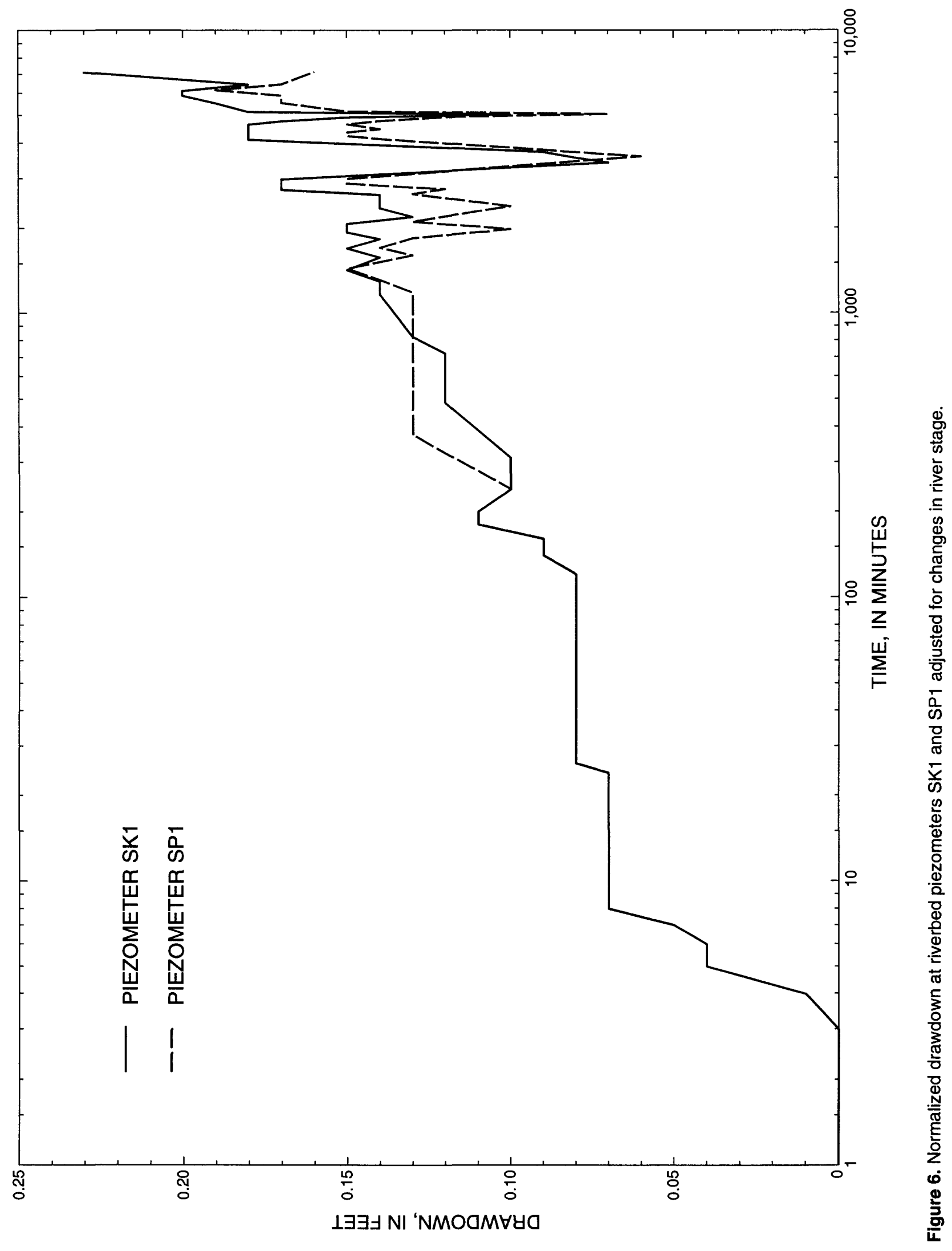




\section{Direction of Ground-Water Flow}

The water-table surface, at the Keyes well and surrounding area, before pumping, reflects the influence of the river as the major sink in the ground-water-flow system (fig. 7A). A streamflow gain of $2.99 \mathrm{ft}^{3} / \mathrm{s}$, measured in the Souhegan River on October 3 and 14, 1988, in the absence of pumping, at the east end of the Milford-Souhegan aquifer, indicates that this is an area where ground water discharges to the river (Harte and Mack, 1992, table 4, p. 22).

The direction of ground-water flow for the lower part of the aquifer (the part of the aquifer that corresponds to the screened zone of the Keyes well) at the Keyes well field after $720 \mathrm{~min}$ into the multiple-well aquifer test is shown in figure $7 B$. The ground-waterflow direction was altered by pumping so that head gradients were increased to the southwest and reversed to the southeast of Keyes well (fig. 7B). A head gradient is induced across the Souhegan River from the Keyes well, in the lower part of the aquifer, by pumping at the Keyes well.

Ground-water-flow directions at the water-table surface, after 720 min of pumping, were nearly unchanged from prepumping directions (fig. $7 A$ ). After about 7,000 min ( 5 days) of pumping at the Keyes well, the direction of ground-water flow at the water table changed slightly. With the exception of the pumped well, the maximum drawdown measured at the water table toward the end of the multiple-well aquifer test at the observation wells was about $1 \mathrm{ft}$. A maximum drawdown of $38 \mathrm{ft}$ measured at the Keyes well was equivalent to a water-table gradient of about $0.9 \mathrm{ft} / \mathrm{ft}$ from the river to the production well. Most drawdowns at the water table were less than $0.5 \mathrm{ft}$, as compared to drawdowns in the lower aquifer of 1 to $3 \mathrm{ft}$.

\section{Trends in Quality of Pumped Water}

Specific conductance, $\mathrm{pH}$, and temperature were collected from water pumped from the Keyes well (appendix 5) to help estimate the contribution of river water to the pumped well and the riverbed hydraulic conductivity. Specific conductance, $\mathrm{pH}$, and temperature of ground water plotted against time from the start of pumping (fig. 8) the results indicate a trend in water quality of the pumped water. The change in water-quality indicates an inflow and mixing of surface water and of ground water of varying quality. Changes in water-quality characteristics are greatest early in the multiple-well aquifer test are more subtle by about $700 \mathrm{~min}$, and are relatively stable towards the end of the test.
The specific conductance of the pumped water increases (fig. 8A) from an ambient value of $250 \mu \mathrm{S} / \mathrm{cm}$ and stabilizes at about $300 \mu \mathrm{S} / \mathrm{cm}$ after $800 \mathrm{~min}$. The specific conductance of the Souhegan River water generally is about 60 to $250 \mu \mathrm{S} / \mathrm{cm}$. The rise in specific conductance of pumped water during the multiple-well aquifer test may reflect an inflow of conductive contaminated ground water offsetting the effects of the influx of low-conductivity river water. Contaminants have been identified in the aquifer upgradient of the Keyes well (Arthur D. Little, Inc., 1994).

The $\mathrm{pH}$ of pumped water shows a similar but less well-defined trend as that for specific conductance (fig. 8). The $\mathrm{pH}$ of the pumped water decreases during the multiple-well aquifer test from about 7.1 to 6.5 . Although the $\mathrm{pH}$ data (fig. $8 \mathrm{~B}$ ) indicate a change in the quality of water recharging the well during the multiple-well aquifer test, there is insufficient information on the $\mathrm{pH}$ of ambient ground water and Souhegan River water to use $\mathrm{pH}$ data in estimating the source, or relative amounts, of water recharging the well.

At the start of the multiple-well aquifer test, the average ambient ground water temperature at the Keyes well field was about $12.8^{\circ} \mathrm{C}$ and Souhegan River water temperature was $6.5^{\circ} \mathrm{C}$. The temperature of the pumped water decreases from $12.8^{\circ} \mathrm{C}$ shortly after the start of the multiple-well aquifer test (fig. $8 \mathrm{C}$ ), and stabilizes after about 600 min to a minimum of $11.2^{\circ} \mathrm{C}$ at $2,720 \mathrm{~min}$. The decrease in the pumped-water temperature is attributed to an influx and mixing of surface water with ground water (the mixing trend is used in the section "Riverbed Leakage" to estimate riverbed leakage).

Three volatile organic contaminants (VOC's) were detected in the pumped water at 1,440 min after the start of multiple-well aquifer test1,2-dichloroethane at $1.7 \mathrm{mg} / \mathrm{L}$, benzene at $70 \mu \mathrm{g} / \mathrm{L}$, and xylenes at $2.14 \mu \mathrm{g} / \mathrm{L}$ (appendix 7). Later in the multiple-well aquifer test, elevated concentrations of VOC's, including acetone $(1,460 \mu \mathrm{g} / \mathrm{L}$ at $1,900 \mathrm{~min})$ and benzene $(250 \mu \mathrm{g} / \mathrm{L}$ at $2,325 \mathrm{~min})$, were detected. From 3,360 to $11,520 \mathrm{~min}$, the end of the multiple-well aquifer test, the pumped water contained a relatively constant concentration of 1,2-dichloroethane (12 to $15 \mu \mathrm{g} / \mathrm{L}$ ) and an unknown organic compound indicated by gas chromatograph data (Patricia Hannon, New Hampshire Department of Environmental Services, written commun., 1988). 


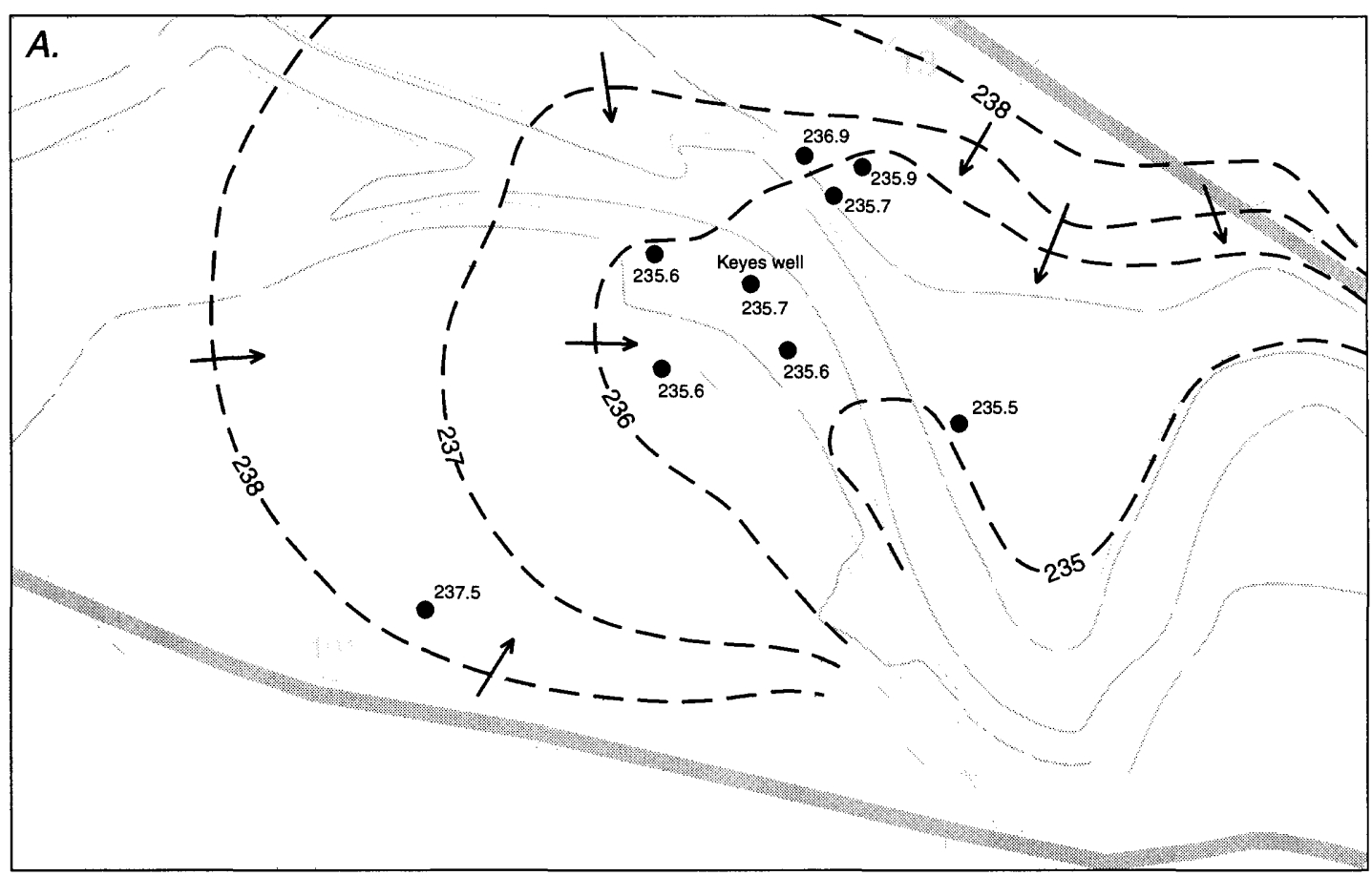

Potentiometric surface prior to pumping

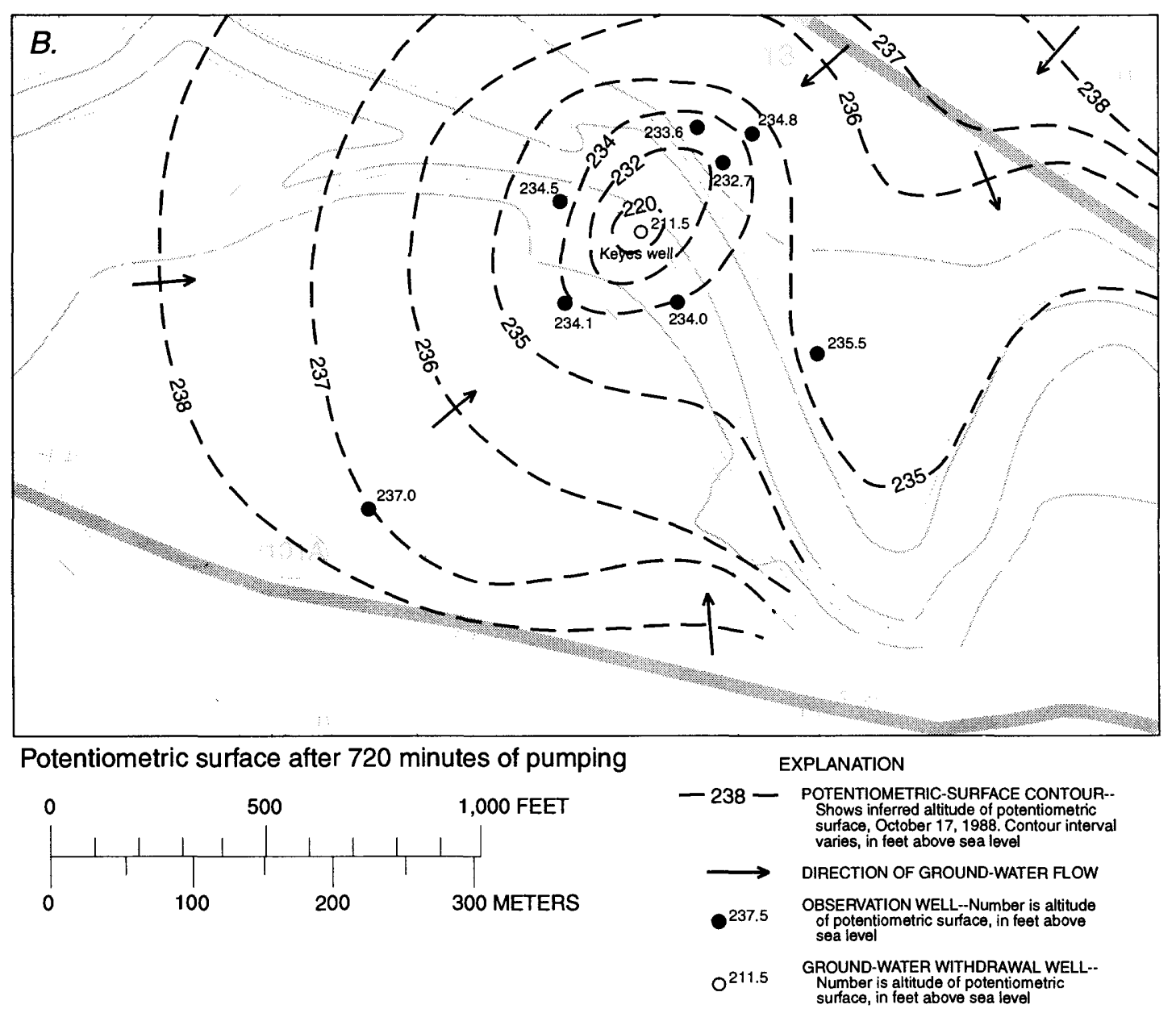

Figure 7. Altitude of potentiometric surface and horizontal ground-water-flow directions before and after 720 minutes of pumping at the Keyes well, Milford, New Hampshire. 

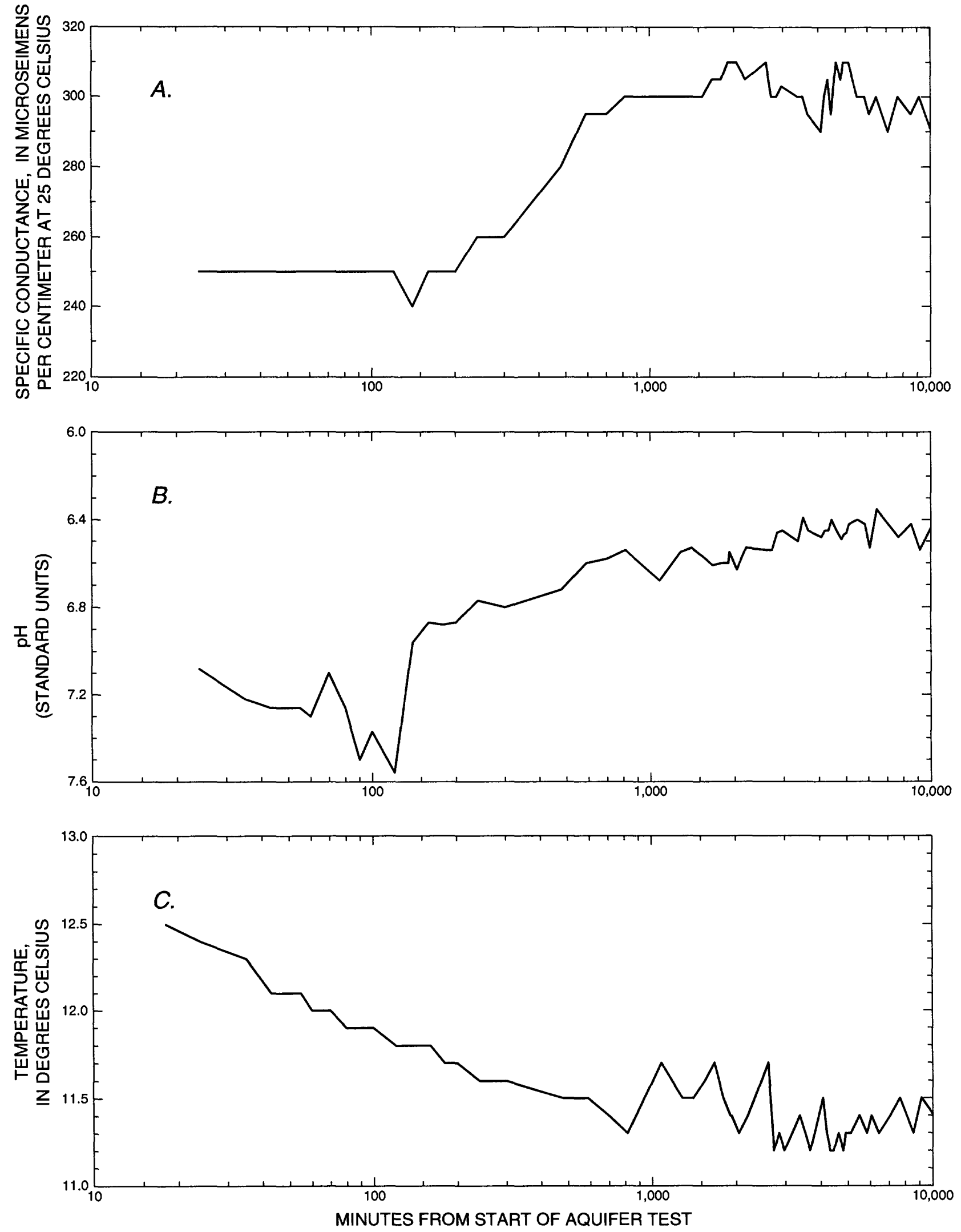

Figure 8. Specific conductance, $\mathrm{pH}$, and temperature of water samples from the Keyes well during the multiple-well aquifer test. 
An investigation done from 1991 to 1994 (Arthur D. Little, Inc., 1994) found elevated concentrations (hundreds to thousands of micrograms per liter) of benzene, toluene, ethylbenzene, and xylene (BETX) about $800 \mathrm{ft}$ south of the Keyes well $(300 \mathrm{ft}$ east of KW1 fig. 1). Near a gasoline station $1,100 \mathrm{ft}$ south and upgradient of the Keyes well, concentrations of these compounds of thousands of micrograms per liter were found (Arthur D. Little, Inc., 1994). BETX were not detected upgradient west of the Keyes well at observation wells KW1 or KW3s and only one detection of toluene $(1.56 \mu \mathrm{g} / \mathrm{L})$ was found at a site across the Souhegan River, about $400 \mathrm{ft}$ east of the Keyes well, or $200 \mathrm{ft}$ north of observation well OW3 (Arthur D. Little, Inc., 1994).

\section{Single-Well Tests}

Single-well tests (or slug tests) in observation wells, and grain-size distributions, sampled during observation-well installation, were analyzed to help determine the hydraulic conductivity of aquifer materials. Slug tests were performed in eight observation wells in September 1993 (appendix 8). Observation well pairs PW1, PW2, and PW3 had been destroyed by 1993 ; therefore, it was not possible to test all observation wells.

For these tests, a slug, with a displacement of $0.4 \mathrm{ft}$ of water, in a 2-inch inside-diameter well, was lowered below the water level in a well and the change in water level from the initial positive displacement (forward test) was monitored by a pressure transducer and recorded with a data logger. After the water level equalized to the original static water level, the slug was removed and the water level rise from the negative displacement was monitored (reverse test). Comparison of forward and reverse tests allowed for verification of testing procedures.

\section{ANALYSIS OF AQUIFER TESTS}

Hydrologic properties at the Keyes well field were estimated from results of the multiple-well aquifer test and slug tests, which sample different aquifer volumes. The multiple-well aquifer test affects a relatively large volume of aquifer-several hundred to a $1,000 \mathrm{ft}$ laterally and tens of feet vertically. The slug test affects a small volume of aquifer-several to tens of feet laterally and a few feet at most vertically, from the well screen. The multiple-well aquifer test provides information on transmissivity, vertical hydraulic conductivity, specific yield, and storage coefficient of the aquifer. Slug tests provide estimates of hydraulic conductivity around the individual well screens and integrate horizontal and vertical hydraulic conductivities.

\section{Multiple-Well Aquifer Test}

The multiple-well aquifer test affects an area up to several hundred feet from the pumped well that makes it possible to assess the hydrologic properties of stratified-drift aquifer, the induced riverbed leakage, and the hydrologic properties of riverbed sediments. The use of a number of analytical methods of analysis were assessed for determining hydrologic properties in this study including DeGlee (in Kruseman and deRidder, 1990, p.76), Neuman, 1974 and 1975; Theis, 1935; and Walton, 1962. The methods account for different aquifer characteristics to varying degrees but all methods assume an homogeneous, infinite aquifer.

\section{Hydrologic Properties of Stratified Drift}

In assessing the Keyes well multiple-well aquifer test, river leakage and the presence of various sediment types (figs. 2 and 3 ) were factors to be addressed in the analysis, both conditions result in an heterogeneous aquifer. The complex heterogeneous system examined in this study is not well suited to analysis by analytical methods. Ideally, this aquifer system would be analyzed by methods in which spatially variable geologic and hydrologic properties of the aquifer could be represented, such as by use of a three-dimensional numerical ground-water-flow model. An analytical analysis of the Keyes well multiple-well aquifer test is presented here to provide approximate estimates of hydrologic aquifer properties, and to illustrate the difficulties in assessing a complex aquifer system using an analytical approach.

Aquifer-test drawdown data were analyzed by use of the methods of Neuman $(1974,1975)$ because the drawdown curves (fig. 4) indicate an unconfined aquifer and the pumped well is partly penetrating. This method assumes a homogeneous, vertically anisotropic, unconfined-aquifer system, and accounts for partially penetrating withdrawal and observation wells. This method can be used to estimate aquifer transmissivity, the ratio of vertical to horizontal 
hydraulic conductivity $\left(k_{z} / k_{h}\right)$, storage coefficient $(S)$, specific yield $\left(S_{y}\right)$, and the ratio of storage coefficient to specific yield $\left(S / S_{y}\right)$. Composite plots of drawdown and type curves for deep (fig. 9) and shallow (fig. 10) observation wells were generated according to methods described by Moench $(1993,1994)$. By this method, a composite set of type curves are matched to a composite set of drawdown curves simultaneously to provide a single match point for the analysis. This method provides a more realistic means of estimating bulk aquifer properties than by matching curves individually (Moench, 1994). Composite plots are separated into deep (fig. 9) and shallow (fig. 10) observation wells to illustrate the differences in the shallow-well and deep-well responses and to aid the visual curve matching process.

The type curves shown in figure 9 were generated through trial-and-error adjusting of the ratios of anisotropy-vertical to horizontal hydraulic conductivity $\left(K_{z} / K_{h}\right)$ and of storage coefficient to specific yield $\left(S / S_{Y}\right)$. For the deep and shallow observation wells, type curves generated using an anisotropy of $\left(K_{z} / K_{h}\right)$ of 0.10 and $S / S_{Y}$ of 0.001 best fit the composite drawdown curves. The composite plots for the deep observation wells (fig. 9) show the effects of aquifer heterogeneity and river leakage.

Theoretically, plots of drawdown versus $t / r^{2}$ (elapsed time divided by distance from the pumped well squared) should overlay with their respective type curve if the aquifer is homogeneous and isotropic (Moench, 1994). Because this is not true, the composite plots clearly indicate a heterogeneous aquifer.

The drawdown curves for the deep observation wells can be grouped into two distinct sets, indicating that the heterogeneity at the site is not random.Wells KW3d and KW4d show an earlier response to pumping indicating a low storage coefficient. Wells KW2d, PW1d, PW2d, and PW3d show a later response to pumping indicating a high storage coefficient. A best fit of the composite type curves to early-time data yields a transmissivity and storage coefficient of about $725 \mathrm{ft}^{2} / \mathrm{d}$ and 0.002 , respectively. The late-time deep-well drawdown data were not sufficient for detailed analysis because of precipitation late in the test period. Hydrologic properties estimated for each individual well are listed in table 1. The deep-well drawdown curves indicate nearly a 3-fold range in transmissivity values. This variation indicates that the aquifer may be sufficiently heterogeneous that the multiple-well aquifer-test results cannot be correctly analyzed by analytical methods. Additionally, the calculated storage coefficient $S(0.002)$ and ratio $S / S_{Y}(0.001)$ indicates that the analysis is affected by river leakage and does not produce realistic values. The actual storage coefficient probably is less than the calculated value. The values reported in table 1 can only be used as estimates of the actual values or to infer the variations in the relative values of the hydrologic properties of the aquifer. Type-curve match points and other information used to calculate the estimates of hydrologic properties are in appendix 9.

A composite plot of shallow observation-well drawdown curves and a plot of corresponding type curves is shown in figure 10. The shallow-well drawdown curves are not as smooth or complete as the deep-well drawdown curves, particularly the drawdown curve for PW2s. The shallow well data curves generally were adequate for estimating approximate transmissivities using early to intermediate data. Composite type curves generated using the ratios $K_{z} / K_{h}$ of 0.10 , and $S / S_{y}$ of 0.001 best fit the composite data plots. The shallow-well analysis was less sensitive to the ratio of $K_{z} / K_{h}$ than the deep well analysis. Based on early to intermediate-time data, composite transmissivity was $3,870 \mathrm{ft}^{2} / \mathrm{d}$.

Table 1. Summary of aquifer hydrologic properties estimated from the Keyes multiple-well aquifer test, Milford, New Hampshire

$\left[\mathrm{ft}^{2} / \mathrm{d}\right.$, square foot per day; --, data curve is inadequate to calculate the hydrologic property]

\begin{tabular}{lcc}
\hline Well & $\begin{array}{c}\text { Transmissivity } \\
\left(\mathbf{f t}^{2} \text { /d) }\right.\end{array}$ & $\begin{array}{c}\text { Storage } \\
\text { coefficient }\end{array}$ \\
\hline KW2s & Shallow Wells & \\
KW3s & 4,980 & - \\
KW4s & 8,040 & -- \\
PW1s & 630 & -- \\
PW2s & 1,830 & -- \\
PW3s & -- & -- \\
\multicolumn{1}{c}{ Average .............. } & 3,870 & -- \\
\hline & Deep Wells & -- \\
\hline KW2d & 1,020 & $3 \times 10^{-3}$ \\
KW3d & 1,180 & $2 \times 10^{-3}$ \\
KW4d & 560 & $1 \times 10^{-3}$ \\
PW1d & 450 & $2 \times 10^{-3}$ \\
PW2d & 690 & $2 \times 10^{-3}$ \\
PW3d & 450 & $1 \times 10^{-3}$ \\
Average …............ & 725 & $2 \times 10^{-3}$ \\
\hline
\end{tabular}



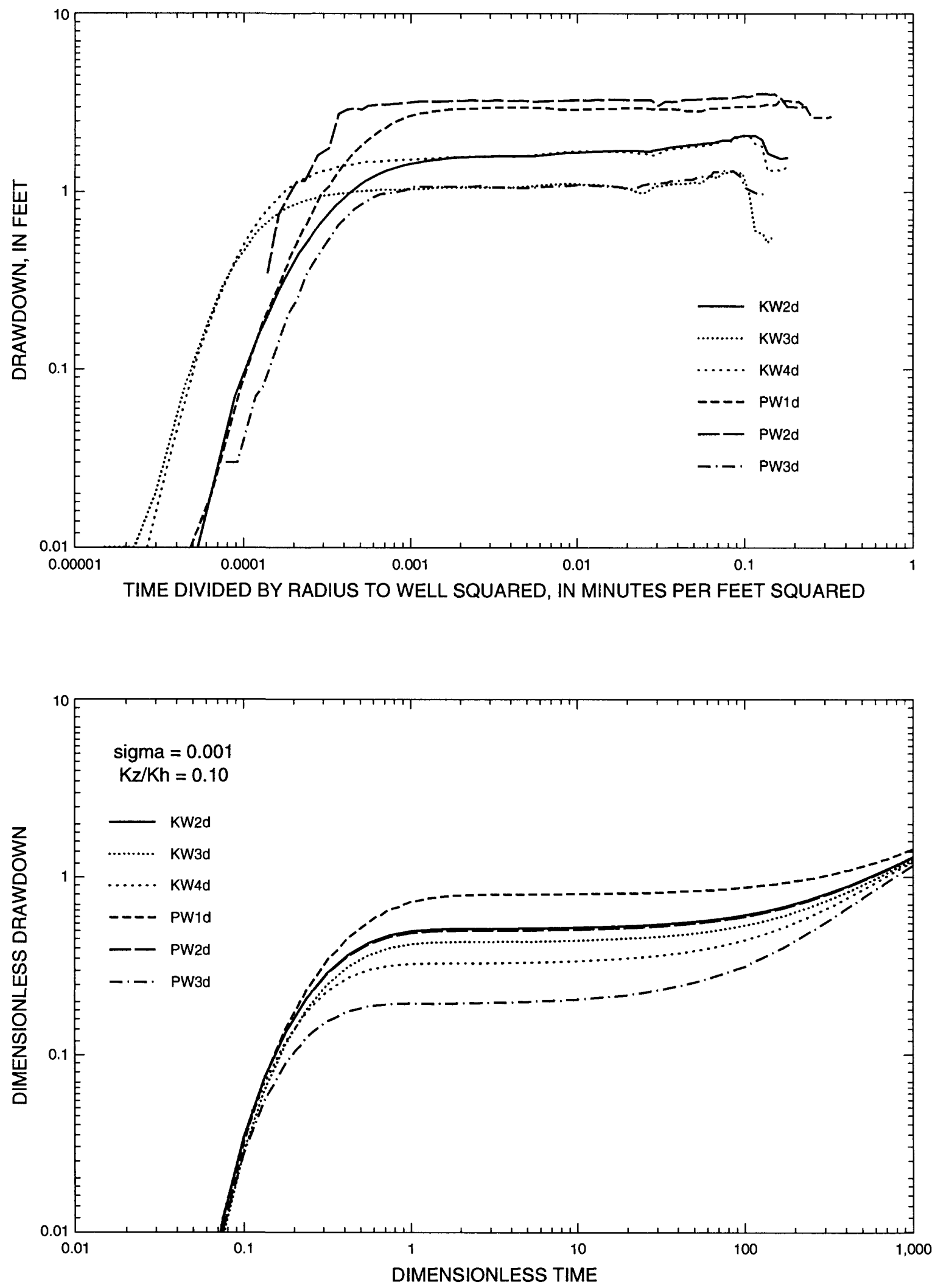

Figure 9. Composite water-level drawdowns in deep observation wells and corresponding type curves during the Keyes multiple-well aquifer test. 

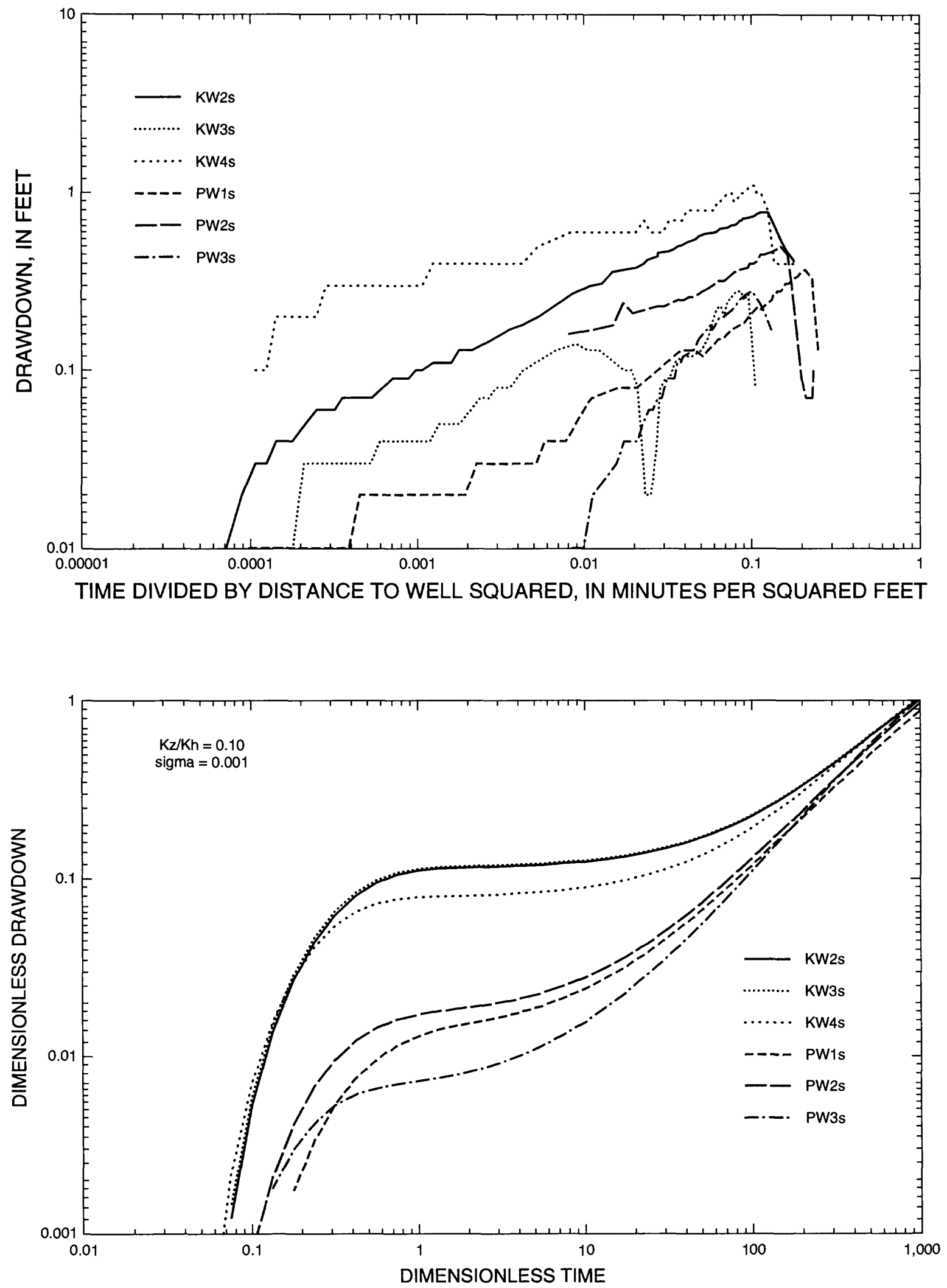

Figure 10. Composite water-level drawdowns in shallow observation wells and corresponding type curves during the Keyes multiple-well aquifer test. 
In summary, although the Keyes well aquifer is not a homogeneous aquifer that can be analyzed by use of the Neuman method (or most analytical methods), some generalizations regarding aquifer properties can be made. From the response of the deep wells to pumping, the lower part of the aquifer has a transmissivity of about $725 \mathrm{ft}^{2} / \mathrm{d}$, with a corresponding horizontal hydraulic conductivity of about $11 \mathrm{ft} / \mathrm{d}$, the storage coefficient is probably less than 0.002 . From the response of the shallow wells, the upper part of the aquifer has a transmissivity of about $3,870 \mathrm{ft}^{2} / \mathrm{d}$. The ratio of vertical to horizontal hydraulic conductivity of the entire aquifer is about 0.10 .

\section{Riverbed Leakage}

The multiple-well aquifer test indicates that ground-water withdrawals lower heads below the river stage and induce river leakage. An effective riverbed vertical hydraulic conductivity and the contribution of river water to the Keyes well were calculated from estimates of river leakage, using a mass balance mixing model, field chemical data collected during the multiple-well aquifer test, and drawdowns from riverbed piezometers.

The temperature of pumped water from the Keyes well, plotted with time from start of the multiple-well aquifer test (fig. $8 \mathrm{C}$ ), indicates that the river contributes to the pumped water. River water had a lower temperature $\left(6.5^{\circ} \mathrm{C}\right)$ than the temperature of ambient ground water $\left(12.8^{\circ} \mathrm{C}\right)$. The ambient groundwater temperature of $12.8^{\circ} \mathrm{C}$ represents an average temperature of ground water near the Keyes well based on temperature data collected in early October $1988^{1}$. The equation for the mass-balance mixing model is

$$
t_{w}=t_{g} p_{g}+t_{r} p_{r}
$$

\footnotetext{
${ }^{1}$ Although an average temperature is used, temperatures are variable in the aquifer. For example, in late October and early November 1993, shallow ground water measured in water-table wells had temperatures of about $11^{\circ} \mathrm{C}$ (Arthur D. Little, Inc., 1994). For that same period, ground water measured in deep wells completed in stratified drift had temperatures of about 7 to $9^{\circ} \mathrm{C}$. Ground water contaminated with VOC's, measured in well $\mathrm{KW} 2 \mathrm{~d}$, had a temperature of $14.7^{\circ} \mathrm{C}$ (Cheryl S. Prague, U.S. Environmental Protection Agency, written commun., 1995).
}

where

$t_{w}$ is temperature of water pumped from the well $\left(11.2^{\circ} \mathrm{C}\right.$ at $\left.2,720 \mathrm{~min}\right)$,

$t_{g}$ is temperature of ambient aquifer ground water $\left(12.8^{\circ} \mathrm{C}\right)$,

$p_{g}$ is fraction of aquifer water contributing to the pumped water, and

$t_{r}$ is temperature of river water $\left(6.5^{\circ} \mathrm{C}\right)$,

$p_{r}$ is fraction of river water contributing to the pumped water.

From the relation

$$
p_{g}+p_{r}=1
$$

substitution of equation (2) into (1) provides a direct solution for $p_{r}$ :

$$
p_{r}=\left(t_{w}-t_{g}\right) /\left(t_{r^{-}} t_{g}\right) .
$$

Solution of equations 2 and 3 indicates that 25 percent of the water contributing to the Keyes well is from the river and 75 percent is from ground water. For the measured pumping rate of $0.65 \mathrm{ft}^{3} / \mathrm{s}$, riverbed leakage was $0.16 \mathrm{ft}^{3} / \mathrm{s}$ of water to the well. However, the actual amount of induced infiltration may exceed $0.16 \mathrm{ft}^{3} / \mathrm{s}$ if the Keyes well does not capture all of the induced infiltration. This condition-termed throughflow (Newsom and Wilson, 1988)-occurs when water leaves the river as the result of induced infiltration, is not captured by the pumped well, and returns to the river downgradient of the pumped well.

The potential for throughflow during the multiple-well aquifer test appears to be minimal given the hydraulic gradients and estimated ground-water fluxes in the aquifer. Newsom and Wilson (1988) provide a method to estimate the potential for throughflow based on a two-dimensional model of ground-water flow and image-well theory. Estimates of throughflow, based on site-specific criteria, are made by computing a parameter called dimensionless pumpage (beta) and comparing figures 1 and 4 in Newsom and Wilson (1988). The dimensionless pumpage parameter also is used to determine the amount of induced infiltration from the river. The equation for determining the dimensionless pumpage parameter, and values from the Keyes well multiple-well aquifer test, are

$$
\text { beta }=Q / q a \cdot p i \cdot d,
$$


where

$Q$ is withdrawal from the well $\left(57,888 \mathrm{ft}^{3} / \mathrm{d}\right)$;

$q a$ is discharge per unit width of ambient ground-water flow $\left(27 \mathrm{ft}^{2} / \mathrm{d}\right)$;

$p i$ is 3.14 ; and

$d$ is distance of the well from river (40 ft).

For the Keyes well test, the solution of equation 4 yields a beta of 17 . Ambient ground-water flow of $27 \mathrm{ft}^{2} / \mathrm{d}$ was determined from seepage gains near the Keyes well of $2.99 \mathrm{ft}^{3} / \mathrm{s}$ (Harte and Mack, 1992) divided by length of reach $9,500 \mathrm{ft}$. Newsom and Wilson (1988, fig. 2) show that beta of 17 is well above the critical value needed for a well to capture all induced inflow from the river.

A potential inflow of 65 percent of total pumpage is possible given the ambient ground-waterflow direction to the river of 52 degrees (the angle between the primary flow direction and the river) Newsom and Wilson (1988, fig. 5). This estimate exceeds the induced infiltration computed from the temperature-mixing model ( 25 percent). It also exceeds the induced infiltration computed from a threedimensional ground-water-flow model (49 percent) described in Harte and Mack (1992) and Olimpio and Harte (1995). Because the analytical solutions developed by Newsom and Wilson (1988) are derived for a two-dimensional system, which assumes a fully penetrating river and well, the two-dimensional-system estimates should be higher than those estimates calculated from the multiple-well aquifer test and from a three-dimensional ground-water-flow model. Because equilibrium was not met during the Keyes well multiple-well aquifer test (water levels in shallow observation wells were still declining during test), estimates of induced infiltration from a steady-state model should be greater than estimates from the multiple-well aquifer test and the temperature-mixing model.

\section{Hydrologic Properties of Riverbed Sediments}

Riverbed vertical hydraulic conductivity was calculated by use of a one-dimensional Darcy flow equation, as follows:

$$
Q=A i K_{r},
$$

where

$Q$ is riverbed leakage $\left(0.16 \mathrm{ft}^{3} / \mathrm{s}\right)$,

$A$ is riverbed area $\left(300,000 \mathrm{ft}^{2}\right)$,

$i$ is hydraulic gradient across the riverbed $(0.0225 \mathrm{ft} / \mathrm{ft})$, and

$K_{r}$ is riverbed vertical hydraulic conductivity.

The solution of equation 5 yields a riverbed hydraulic conductivity of approximately $2 \mathrm{ft} / \mathrm{d}$. The parameters specified for estimating riverbed hydraulic conductivity (equation 5) are derived from the calculated river leakage (using the temperature-mixing model), estimates of riverbed leakage area, and average hydraulic gradients. The riverbed area $\left(300,000 \mathrm{ft}^{2}\right)$ is the river width times the riverbed length across which leakage is estimated to have occurred. The river width adjacent to the Keyes well is $75 \mathrm{ft}$. The length across which leakage occurred was estimated by extrapolating drawdown at the piezometers out to a $0.02 \mathrm{ft}$ drawdown point for a total length of $4,000 \mathrm{ft}$. The distance-drawdown point of $0.02 \mathrm{ft}$ was chosen to coincide with head difference between river and riverbed head and represents the point of zero vertical hydraulic gradient, or no flow from the river to the aquifer. A hydraulic gradient across the riverbed of 0.0225 was calculated from an average piezometer drawdown of $0.09 \mathrm{ft}$ and assuming a riverbed thickness of $4 \mathrm{ft}$. Given the uncertainties involved in the understanding and measurement of river and aquifer interactions, $2 \mathrm{ft} / \mathrm{d}$ probably is within an order of magnitude of the actual mean value and is a reasonable estimate of riverbed vertical hydraulic conductivity.

A sample of riverbed material collected adjacent to the Keyes well was analyzed for grain-size distribution and a hydraulic conductivity of $10 \mathrm{ft} / \mathrm{d}$ was calculated. A riverbed-sediment sample was selected from fine-grained layers because the fine-grained layers would restrict flow and would dominate the effective hydraulic conductivity. Riverbed hydraulic conductivity estimated by the grain-size analysis is similar to the riverbed hydraulic conductivity estimated by the temperature-mixing model. 


\section{Single-Well Tests}

Slug tests were analyzed by the Bouwer and Rice (1976) method, this method assumes unconfined aquifer conditions and integrates the effects of horizontal and vertical flow. Vertical flow can occur around the well screen of partially penetrating wells. Hydraulic conductivity also was estimated at eight wells by use of a grain-size distribution and hydraulic conductivity relation described by Olney (1983). This method, developed from an empirical relation between an effective grain size and hydraulic conductivity for New England glacial sands, provides a bulk estimate of hydraulic conductivity but does not account for the directional heterogeneity of the aquifer. This method has been used by Harte and Mack (1992, p. 30-38), and other studies, to provide an approximate estimate of hydraulic conductivity where no hydrologic data exists. A summary of results of slug tests (slug and grain-size analysis) are provided in table 2.

Information used to calculate the estimates of hydraulic conductivity are provided in appendix 10 . The analyses indicate that hydraulic conductivities from shallow wells are greater than those from deep wells. However, the slug-test results indicate greater ranges and values of hydraulic conductivities than the grain-size analysis. Hydraulic conductivities estimated from forward and reverse slug tests compare favorably. Hydraulic conductivities at shallow wells range from 5.3 to $128 \mathrm{ft} / \mathrm{d}$ (forward tests). Hydraulic conductivities at deep wells range from 1.9 to $76 \mathrm{ft} / \mathrm{d}$ (forward tests). Hydraulic conductivities estimated from grain-size analysis of sediment samples from two shallow wells were 15 and $20 \mathrm{ft} / \mathrm{d}$ and from three deep wells were about $5 \mathrm{ft} / \mathrm{d}$.

The estimated hydraulic conductivities based on slug tests indicate that hydraulic conductivity is higher to the west of the Keyes well in the upper and lower intervals of the aquifer than in other areas near the Keyes well. This is consistent with lithologic observations which indicate that coarse-grained deposits in a narrow west to east band several hundred feet in width.

\section{Comparison of Multiple-Well Aquifer Tests and Slug Tests}

Comparison of estimates of hydraulic conductivity from aquifer and slug tests allow for a comparison of estimates of hydraulic conductivity over different scales of measurement. Other studies have indicated that measurements of hydraulic conductivity in glacial and fluvial materials are scale dependent and should be examined with respect to operational scale of measurement (Bradbury and Muldoon, 1990). Hydraulic conductivity computed from slug tests reflects small sample volumes. The data from slug tests can be correlated to hydraulic conductivities estimated from grain-size analyses of material from the well screen zone. Hydraulic conductivity computed from the Keyes well multiple-well aquifer test reflects an

Table 2. Summary of hydraulic conductivity estimates from multiple-well aquifer tests and slug tests, Keyes well, Milford, New Hampshire

[Information used to calculate the estimates of hydraulic conductivity are provided in appendix $10 . \mathrm{ft} / \mathrm{d}$, foot per day; - , no data]

\begin{tabular}{|c|c|c|c|c|}
\hline \multirow{3}{*}{ Well } & \multicolumn{3}{|c|}{$\begin{array}{l}\text { Aquifer tests for hydraulic } \\
\text { conductivity }\end{array}$} & \multirow{3}{*}{$\begin{array}{l}\text { Grain-size } \\
\text { analysis for } \\
\text { hydraulic } \\
\text { conduc- } \\
\text { tivity } \\
\text { (ft/d) }\end{array}$} \\
\hline & \multirow{2}{*}{$\begin{array}{c}\text { Multiple- } \\
\text { well } \\
\text { (ft/d) }\end{array}$} & \multicolumn{2}{|c|}{ Slug test } & \\
\hline & & $\begin{array}{c}\text { Forward } \\
\text { analysis } \\
(\mathrm{ft} / \mathrm{d})\end{array}$ & $\begin{array}{c}\text { Reverse } \\
\text { analysis } \\
\text { (ft/d) }\end{array}$ & \\
\hline \multicolumn{5}{|c|}{ Shallow Wells } \\
\hline KW2s & 58 & 32 & - & 5 \\
\hline KW3s & 150 & 128 & 154 & 15 \\
\hline KW4s & 10 & 5.3 & 5.4 & 20 \\
\hline PW1s & 36 & -- & -- & -- \\
\hline PW2s & - & -- & - & -- \\
\hline PW3s & 38 & -- & -- & -- \\
\hline Average... & 58 & 55 & 80 & 13 \\
\hline \multicolumn{5}{|c|}{ Deep Wells } \\
\hline KW1 & -- & 4.6 & 2.9 & 5 \\
\hline KW2d & 8 & 1.9 & 1.7 & 5 \\
\hline KW3d & 14 & 20 & 26 & 5 \\
\hline KW4d & 8 & 8.6 & 9.4 & 6 \\
\hline PW1d & 14 & -- & -- & 5 \\
\hline PW2d & 7 & -- & -- & -- \\
\hline PW3d & 7 & -- & -- & - \\
\hline ow3 & -- & 76 & 105 & -- \\
\hline Average... & 10 & 22 & 29 & 5.2 \\
\hline
\end{tabular}


average of a large sample volume and integrates the effects of the upper and lower parts of the aquifer. The multiple-well aquifer test also incorporates the effects of local boundary conditions including the Souhegan River and variations in saturated thickness.

A comparison of hydraulic conductivity estimates from the slug, small-scale tests with the large-scale multiple-well aquifer test shows similar values of hydraulic conductivity (table 2 ). In areas where multiple-well aquifer test results indicate a relatively high hydraulic conductivity, slug tests also indicate a relatively high hydraulic conductivity. Aquifer and slug tests indicates a high hydraulic conductivity west of the Keyes well, and low hydraulic conductivity to the south. The slug test results indicate a slightly wider range of hydraulic conductivity values, than the multiple-well aquifer test results, because of the slug test's small sample volume and dependance on local heterogeneity. The multiple-well aquifer test samples a larger volume of the aquifer which effectively averages differences in hydraulic conductivity in that sample volume.

Estimates from the multiple-well aquifer test could not be compared at observation well OW3, to the east of the Keyes well (fig. 1), because drawdown was not measurable at this well during the multiple-well aquifer test. Because well OW3 was screened in coarsegrained deposits that are in hydraulic connection with the Souhegan River, it was not possible to produce a drawdown at this well by pumping at the Keyes well. Therefore, the location of the observation wells for the multiple-well aquifer test were not adequate to estimate the high transmissivity east of the Keyes well. Results of the slug tests at this well indicate a high hydraulic conductivity ( 76 and $105 \mathrm{ft} / \mathrm{d}$, table 2 ), which is consistent with the interpreted geologic section (fig. 3).

\section{SUMMARY AND CONCLUSIONS}

An multiple-well aquifer test of the Keyes well was done on October 13, 1988, and continued for 7 days at a pumping rate of $300 \mathrm{gal} / \mathrm{min}$. During the test water levels at 13 observation wells and 6 piezometers in the Keyes well field, and the water quality of the pumped well were monitored. Seven wells were screened at the same depth as the Keyes well, six wells were screened at the water-table surface, and six piezometers were set in the riverbed of the Souhegan River. The aquifer in the Keyes well area consists of from 0 to $80 \mathrm{ft}$ of unconsolidated glacial sediments that fill a buried
pre-Pleistocene valley. The glacial sediments at the well field are generally fine-grained sands and silts with the exception of a narrow area of coarse-gained sands and gravels within which the Keyes well is screened. The coarse-grained glacial sediments most likely represent a buried esker or ice-channel deposit and account for the high yield of this well $(0.14 \mathrm{Mgal} / \mathrm{d})$.

The ground-water-flow direction at the Keyes well field under unstressed conditions is towards the Souhegan River, which is gaining near the well field. During the Keyes well multiple-well aquifer test, ground-water-flow directions in the Keyes well field were altered so that flow was towards the Keyes well in the lower part of the aquifer. A downward head gradient was induced, in the lower part of the aquifer across the Souhegan River from the Keyes well, during pumping. Ground-water flow at the water table is nearly unchanged during the multiple-well aquifer test with the exception of the area near the Keyes well where the water table was drawn down.

Trends in specific conductance, $\mathrm{pH}$, and temperature of water pumped from the Keyes well indicated that induced infiltration and capture of river water occurred during the multiple-well aquifer test. The temperature of the pumped water showed a clear trend of the influence of induced infiltration of river water at the well. Ground-water temperature at the Keyes well before the aquifer-test withdrawals was $12.8^{\circ} \mathrm{C}$. After $600 \mathrm{~min}$ of pumping, the temperature of pumped water stabilized at about $11.2^{\circ} \mathrm{C}$. Stream-water temperature was $6.5^{\circ} \mathrm{C}$ at the time of the multiple-well aquifer test. After 1,440 min of pumping, 1,2-dichloroethane was detected at $1.7 \mu \mathrm{g} / \mathrm{L}$ and from $3,360 \mathrm{~min}$ to the end of the test the concentration remained constant at 12 to $15 \mu \mathrm{g} / \mathrm{L}$.

A transmissivity of about $725 \mathrm{ft}^{2} / \mathrm{d}$ was estimated for the lower part of the aquifer where the Keyes well is screened. The horizontal hydraulic conductivity of the lower part of the aquifer, with the exception of the immediate vicinity of the Keyes well, is about $10 \mathrm{ft} / \mathrm{d}$. The horizontal hydraulic conductivity of the upper part of the aquifer, from analysis of individual observation well data, is about $58 \mathrm{ft} / \mathrm{d}$ and ranges from about 10 to $150 \mathrm{ft} / \mathrm{d}$. The ratio of vertical to horizontal hydraulic conductivity was estimated to be about 0.10 . The storage coefficient was estimated to be less than 0.002 . Although the aquifer was unconfined, delayed gravity drainage effects were limited during the 7 day test, because of river leakage and because a multiple-well aquifer test greater than 7 days is needed. 
Riverbed leakage was estimated to be $0.16 \mathrm{ft}^{3} / \mathrm{s}$, or about 25 percent of the water pumped from the Keyes well. Riverbed hydraulic conductivity, based on riverbed leakage, drawdown at the piezometers, and Darcian flow, was estimated to be $2 \mathrm{ft} / \mathrm{d}$.

Hydraulic conductivities of the aquifer estimated by slug tests $(1.7$ to $154 \mathrm{ft} / \mathrm{d})$ were comparable to those estimated from the multiple-well aquifer test (10 to $150 \mathrm{ft} / \mathrm{d}$ ). The slug tests gave a slightly wider range of hydraulic conductivity values than the multiple-well aquifer test because of their small sample volume and dependence on local heterogeneity. The multiple-well aquifer test affects a larger volume of the aquifer, than the slug test, which effectively averages hydraulic conductivity for a large aquifer volume. For hydraulic conductivities estimated at individual wells by the both slug tests and the multiple-well aquifer test, the range and distribution of the estimates are similar. Both tests indicate an increase in hydraulic conductivity west of Keyes well, and a decrease in hydraulic conductivity to the south. Results of the small (slug) and large scale (multiple-well) tests indicate the scale dependency of hydraulic-conductivity measurements.

Drawdown responses at observation wells during the Keyes well test show the effect of aquifer heterogeneity and river leakage. The proximity of the Keyes well to significant hydrologic boundaries (that is, the Souhegan River and the limited areal extent of the aquifer) complicates the analysis of the Keyes well multiple-well aquifer test. Estimates of hydrologic properties of such a complex hydrogeologic system with significant surface- and ground-water-flow interactions are approximate. An analysis of such a multiple-well aquifer test would best be evaluated using a numerical three-dimensional ground-water-flow model. This model would accommodate the varied and complex aquifer boundaries conditions found at the Keyes well.

\section{REFERENCES CITED}

Arthur D. Little, Inc., 1994, Draft remedial investigation for Fletcher's Paint site, Milford, New Hampshire: Cambridge, Mass., v. 2, sections 4-7, reference no. $62360,67 \mathrm{p}$.

Bouwer, Herman and Rice, R.C., 1976, A slug test method for determining hydraulic conductivity of unconfined aquifers with completely or partially penetrating wells: Water Resources Research, v. 12, no. 3, p. 423-428.
Bradbury, K.R., and Muldoon, M.A., 1990, Hydraulic conductivity determinations in unlithified glacial and fluvial materials in D.M. Nielson and A.L. Johnson, eds., Ground water and vadose zone monitoring: ASTM STP 1053, American Society for Testing and Materials, Philadelphia, p. 138-151.

Harte, P.T., and Mack, T.J., 1992, Geohydrology of, and simulation of ground-water flow in, the MilfordSouhegan glacial-drift aquifer, Milford, New Hampshire: U.S. Geological Survey Water-Resources Investigations Report 91-4177, 75 p.

Koteff, Carl, 1970, Surficial geologic map of the Milford quadrangle, Hillsborough County, New Hampshire: U.S. Geological Survey Geologic Quadrangle Map GQ881 , scale 1:62,500.

Kruseman, G.P., and de Ridder, N.A., 1990, Analysis and evaluation of pumping test data: Wageningen, The Netherlands, International Institute for Land Reclamation and Improvement, $377 \mathrm{p}$.

Moench, A.F., 1993, Computation of type curves for flow to partially penetrating wells in water-table aquifers: Ground Water, v. 31, no. 6, p. 966-971.

- 1994, Specific yield as determined by type curve analysis of aquifer-test data: Ground Water, v. 32, no. 6 , p. 949-957.

Neuman, S.P., 1974, Effect of partial penetration on flow in unconfined aquifers considering delayed gravity response: Water Resources Research, v. 10, no. 2, p. 303-312.

1975, Analysis of pumping test data from anisotropic unconfined aquifers considering delayed gravity response: Water Resources Research, v. 11, no. 2, p. 329-342.

Newsom and Wilson, 1988, Flow of groundwater to a well near a stream-Effect of ambient groundwater direction: Ground Water, v. 26, no. 6, p. 703-711.

Olimpio, J.R., and Harte, P.T., 1995, Reassessment of hydrogeologic data and refinement of a regional groundwater-flow model for the Milford-Souhegan glacial-drift aquifer, Milford, New Hampshire: U.S. Geological Survey Open-File Report 95-281.

Olney, S.L., 1983, An investigation of the relationship between coefficient of permeability and effective grain size of unconsolidated sands: Boston Mass., Boston University, unpublished Master's thesis, $61 \mathrm{p}$.

Theis, C.V., 1935, The relation between the lowering of the piezometric surface and the rate and duration of discharge of a well using groundwater storage: American Geophysical Union Trans., v. 16, p. 519-524.

Walton, W.C., 1962, Selected analytical methods for well and aquifer evaluation: Illinois State Water Survey Bulletin, no. $49,81 \mathrm{p}$. 
APPENDIX 1. Well and piezometer construction data, Milford, New Hampshire 
Appendix 1. Well and piezometer construction data, Milford, New Hampshire

[Other identifier: From Harte and Mack (1992). ft, foot; in., inch; --, no data]

\begin{tabular}{|c|c|c|c|c|c|c|c|}
\hline $\begin{array}{c}\text { Well or } \\
\text { piezometer }\end{array}$ & $\begin{array}{c}\text { Other } \\
\text { identifier }\end{array}$ & $\begin{array}{c}\begin{array}{c}\text { Distance } \\
\text { from }\end{array} \\
\text { Keyes well } \\
\text { (ft) }\end{array}$ & $\begin{array}{l}\text { Altitude of } \\
\text { measure- } \\
\text { ment point } \\
\text { (ft above } \\
\text { sea level) }\end{array}$ & $\begin{array}{c}\text { Altitude of } \\
\text { land } \\
\text { surface } \\
\text { ( } \mathrm{ft} \text { above } \\
\text { sea level) }\end{array}$ & $\begin{array}{l}\text { Diameter } \\
\text { (in.) }\end{array}$ & $\begin{array}{l}\text { Screened } \\
\text { interval } \\
\text { below } \\
\text { land } \\
\text { surface } \\
\text { (ft) }\end{array}$ & $\begin{array}{c}\text { Altitude of } \\
\text { water-level } \\
\text { (ft above } \\
\text { sea level) }\end{array}$ \\
\hline KEYES & 126 & 0 & 250 & 240.1 & 18 & $50-60$ & 235.58 \\
\hline KWOBS & -- & 2 & 248.47 & -- & 2 & $?-60$ & -- \\
\hline KW1 & 1 & 870 & 250.71 & 248.7 & 2 & $53-55$ & 237.26 \\
\hline KW2s & 142 & 236 & 248.45 & 246.1 & 2 & $22-24$ & 235.90 \\
\hline KW2d & 2 & 237 & 248.61 & 246.6 & 2 & $59-61$ & 235.79 \\
\hline KW3s & 143 & 259 & 247.67 & 246.0 & 2 & $18.6-20.6$ & 235.52 \\
\hline KW3d & 3 & 251 & 246.84 & 244.8 & 2 & $50.7-52.7$ & 235.59 \\
\hline KW4s & 144 & 237 & 245.28 & 244.3 & 1.25 & $19.2-21.2$ & 235.58 \\
\hline KW4d & 4 & 237 & 245.31 & 243.3 & 2 & $54.7-56.7$ & 235.61 \\
\hline PW1s & 145 & 176 & 253.76 & 252.0 & 2 & $18.0-20.0$ & 235.69 \\
\hline PW1d & 132 & 176 & 253.75 & 251.8 & 2 & $62.0-64.0$ & 235.65 \\
\hline PW2s & 146 & 208 & 255.79 & 253.7 & 2 & $21.0-23.0$ & 235.69 \\
\hline PW2d & 133 & 208 & 255.77 & 253.8 & 2 & $62.0-64.0$ & 235.72 \\
\hline PW3s & 147 & 276 & 255.66 & 253.7 & 2 & $22.0-24.0$ & 236.01 \\
\hline PW3d & 134 & 276 & 255.67 & 253.7 & 2 & $62.0-64.0$ & 235.97 \\
\hline SK1 & -- & 41 & 235.60 & -- & 1.25 & $5-7$ & 234.93 \\
\hline SK2 & -- & 81 & 235.79 & -- & 1.25 & $5-7$ & 234.8 \\
\hline SK3 & -- & 103 & 235.78 & -- & 1.25 & $5-7$ & 234.79 \\
\hline SP1 & -- & 115 & 237.60 & -- & 1.25 & $5-7$ & 236.92 \\
\hline SP2 & -- & 167 & 236.25 & -- & 1.25 & $5-7$ & 235.26 \\
\hline SP3 & -- & 146 & 235.92 & -- & 1.25 & $5-7$ & 234.93 \\
\hline OW3 & 135 & 440 & 241.4 & 241.4 & 2.25 & $40-50$ & -. \\
\hline
\end{tabular}

Appendix $1 \quad 25$ 
APPENDIX 2. Water-level drawdowns at observation wells during the Keyes multiple-well aquifer test, Milford, New Hampshire 

Appendix 2. Water-level drawdowns at observation wells during the Keyes multiple-well aquifer test, Milford, New Hampshire

[min, minute; ft, feet; --, no data]

\begin{tabular}{|c|c|c|c|c|c|c|c|c|}
\hline$\underset{(\min )}{t}$ & $\begin{array}{c}\text { Well } \\
\text { KW2d } \\
\text { (ft) }\end{array}$ & $\begin{array}{c}\text { Well } \\
\text { KW2s } \\
\text { (ft) }\end{array}$ & $\underset{(\min )}{t}$ & $\begin{array}{l}\text { Well } \\
\text { KW3d } \\
\text { (ft) }\end{array}$ & $\begin{array}{c}\text { Well } \\
\text { KW3s } \\
\text { (ft) }\end{array}$ & $\underset{(\min )}{t}$ & $\begin{array}{l}\text { Well } \\
\text { KW4d } \\
\text { (ft) }\end{array}$ & $\begin{array}{c}\text { Well } \\
\text { KW4s } \\
\text { (ft) }\end{array}$ \\
\hline 0.5 & 0.00 & 0.00 & 0.5 & 0.00 & 0.00 & 0.5 & 0.00 & 0.00 \\
\hline 1.0 & .00 & .00 & 1.0 & .01 & .00 & 1.0 & .00 & .00 \\
\hline 1.5 & .00 & .00 & 1.5 & .01 & .00 & 1.5 & .01 & .00 \\
\hline 2.0 & .00 & .00 & 2.0 & .02 & .00 & 2.0 & .03 & .00 \\
\hline 3.0 & .01 & .00 & 3.0 & .08 & .00 & 3.0 & .12 & .03 \\
\hline 4.0 & .03 & .01 & 4.0 & .17 & .00 & 4.0 & .25 & .07 \\
\hline 5.0 & .07 & .02 & 5.0 & .29 & .00 & 5.0 & .41 & .09 \\
\hline 6.0 & .11 & .03 & 6.0 & .40 & .00 & 6.0 & .56 & .17 \\
\hline 7.0 & .16 & .03 & 7.0 & .49 & .00 & 7.0 & .70 & .19 \\
\hline 8.0 & .21 & .04 & 8.0 & .59 & .01 & 8.0 & .82 & .21 \\
\hline 9.0 & .27 & .04 & 9.0 & .66 & .01 & 9.0 & .92 & .24 \\
\hline 10.0 & .33 & .04 & 10.0 & .72 & .01 & 10.0 & 1.02 & .25 \\
\hline 12.0 & .45 & .05 & 12.0 & .81 & .01 & 12.0 & 1.15 & .27 \\
\hline 14.0 & .55 & .06 & 14.0 & .86 & .03 & 14.0 & 1.22 & .29 \\
\hline 16.0 & .66 & .06 & 16.0 & .90 & .03 & 16.0 & 1.30 & .32 \\
\hline 18.0 & .75 & .06 & 18.0 & .92 & .03 & 18.0 & 1.32 & .33 \\
\hline 20.0 & .84 & .07 & 20.0 & .95 & .03 & 20.0 & 1.37 & .33 \\
\hline 22.0 & .91 & .07 & 22.0 & .96 & .03 & 22.0 & 1.40 & .34 \\
\hline 24.0 & .98 & .07 & 24.0 & .97 & .03 & 24.0 & 1.41 & .34 \\
\hline 26.0 & 1.04 & .07 & 26.0 & .98 & .03 & 26.0 & 1.43 & .35 \\
\hline 28.0 & 1.10 & .07 & 28.0 & .98 & .03 & 28.0 & 1.45 & .37 \\
\hline 30.0 & 1.15 & .07 & 30.0 & 1.00 & .03 & 30.0 & 1.47 & .37 \\
\hline 35.0 & 1.24 & .08 & 35.0 & 1.01 & .03 & 35.0 & 1.47 & .37 \\
\hline 40.0 & 1.31 & .09 & 40.0 & 1.02 & .04 & 40.0 & 1.49 & .38 \\
\hline 45.0 & 1.36 & .09 & 45.0 & 1.03 & .04 & 45.0 & 1.50 & .38 \\
\hline 50.0 & 1.40 & .09 & 50.0 & 1.03 & .04 & 50.0 & 1.51 & .39 \\
\hline 55.0 & 1.43 & .10 & 55.0 & 1.03 & .04 & 55.0 & 1.51 & .39 \\
\hline 60.0 & 1.45 & .10 & 60.0 & 1.03 & .04 & 60.0 & 1.52 & .39 \\
\hline 70.0 & 1.49 & .11 & 70.0 & 1.04 & .04 & 70.0 & 1.53 & .40 \\
\hline
\end{tabular}


Appendix 2. Water-level drawdowns at observation wells during the Keyes multiple-wellaquifer test, Milford, New Hampshire-Continued

\begin{tabular}{|c|c|c|c|c|c|c|c|c|}
\hline$\underset{(\min )}{t}$ & $\begin{array}{c}\text { Well } \\
\text { KW2d } \\
\text { (ft) }\end{array}$ & $\begin{array}{c}\text { Well } \\
\text { KW2s } \\
\text { (ft) }\end{array}$ & $\underset{(\min )}{t}$ & $\begin{array}{c}\text { Well } \\
\text { KW3d } \\
\text { (ft) }\end{array}$ & $\begin{array}{c}\text { Well } \\
\text { KW3s } \\
\text { (ft) }\end{array}$ & $\underset{(\min )}{t}$ & $\begin{array}{c}\text { Well } \\
\text { KW4d } \\
\text { (ft) }\end{array}$ & $\begin{array}{c}\text { Well } \\
\text { KW4s } \\
\text { (ft) }\end{array}$ \\
\hline 80.0 & 1.51 & 0.11 & 80.0 & 1.04 & 0.04 & 80.0 & 1.54 & 0.40 \\
\hline 90.0 & 1.53 & .11 & 90.0 & 1.05 & .05 & 90.0 & 1.55 & .41 \\
\hline 100 & 1.55 & .13 & 100 & 1.06 & .05 & 100 & 1.56 & .42 \\
\hline 120 & 1.56 & .13 & 120 & 1.06 & .05 & 120 & 1.57 & .43 \\
\hline 140 & 1.57 & .14 & 140 & 1.06 & .06 & 140 & 1.57 & .44 \\
\hline 160 & 1.57 & .15 & 160 & 1.06 & .07 & 160 & 1.58 & .45 \\
\hline 180 & 1.58 & .16 & 180 & 1.06 & .07 & 180 & 1.58 & .46 \\
\hline 200 & 1.58 & .17 & 200 & 1.06 & .08 & 200 & 1.59 & .47 \\
\hline 240 & 1.58 & .18 & 240 & 1.06 & .08 & 240 & 1.57 & .49 \\
\hline 300 & 1.58 & .20 & 290 & 1.06 & .10 & 300 & 1.60 & .56 \\
\hline 480 & 1.65 & .27 & 460 & 1.10 & .13 & 474 & 1.67 & .61 \\
\hline 610 & 1.66 & .30 & 603 & 1.11 & .14 & 612 & 1.69 & .62 \\
\hline 720 & 1.68 & .31 & 708 & 1.10 & .13 & 716 & 1.68 & .63 \\
\hline 832 & 1.69 & .36 & 827 & 1.10 & .13 & 836 & 1.68 & .65 \\
\hline 1,160 & 1.70 & .38 & 1,160 & 1.07 & .10 & 115 & 1.67 & .68 \\
\hline 1,285 & 1.70 & .40 & 1,285 & 1.06 & .10 & 1,291 & 1.64 & .70 \\
\hline 1,350 & 1.69 & .42 & 1,407 & 1.03 & .08 & 1,413 & 1.64 & .69 \\
\hline 1,560 & 1.68 & .44 & 1,560 & .99 & .02 & 1,555 & 1.60 & .67 \\
\hline 1,684 & 1.70 & .46 & 1,684 & .99 & .02 & 1,675 & 1.61 & .68 \\
\hline 1,818 & 1.74 & .47 & 1,832 & 1.03 & .04 & 1,825 & 1.69 & .72 \\
\hline 1,918 & 1.76 & .48 & 1,922 & 1.07 & .08 & 1,915 & 1.72 & .76 \\
\hline 2,054 & 1.78 & .50 & 2,064 & 1.08 & .09 & 2,081 & 1.74 & .77 \\
\hline 2,176 & 1.79 & .51 & 2,182 & 1.08 & .09 & 2,171 & 1.74 & .78 \\
\hline 2,335 & 1.80 & .53 & 2,340 & 1.10 & .11 & 2,331 & 1.76 & .81 \\
\hline 2,618 & 1.83 & .55 & 2,615 & 1.11 & .12 & 2,620 & 1.79 & .84 \\
\hline 2,726 & 1.83 & .57 & 2,723 & 1.11 & .12 & 2,728 & 1.79 & .85 \\
\hline 2,847 & 1.84 & .58 & 2,843 & 1.11 & .12 & 2,847 & 1.80 & .86 \\
\hline 2,967 & 1.85 & .59 & 2,963 & 1.11 & .12 & 2,969 & 1.80 & .86 \\
\hline 3,400 & 1.88 & .60 & 3,390 & 1.13 & .13 & 3,404 & 1.83 & .89 \\
\hline 3,535 & 1.88 & .61 & 3,531 & 1.12 & .14 & 3,539 & 1.84 & .90 \\
\hline
\end{tabular}


Appendix 2. Water-level drawdowns at observation wells during the Keyes multiple-wellaquifer test, Milford, New Hampshire-Continued

\begin{tabular}{|c|c|c|c|c|c|c|c|c|}
\hline$\underset{(\min )}{t}$ & $\begin{array}{c}\text { Well } \\
\text { KW2d } \\
\text { (ft) }\end{array}$ & $\begin{array}{c}\text { Well } \\
\text { KW2s } \\
\text { (ft) }\end{array}$ & $\underset{(\min )}{t}$ & $\begin{array}{c}\text { Well } \\
\text { KW3d } \\
\text { (ft) }\end{array}$ & $\begin{array}{c}\text { Well } \\
\text { KW3s } \\
\text { (ft) }\end{array}$ & $\underset{(\min )}{t}$ & $\begin{array}{c}\text { Well } \\
\text { KW4d } \\
\text { (ft) }\end{array}$ & $\begin{array}{c}\text { Well } \\
\text { KW4s } \\
\text { (ft) }\end{array}$ \\
\hline 3,680 & 1.89 & 0.63 & 3,681 & 1.12 & 0.15 & 3,689 & 1.84 & 0.91 \\
\hline 4,094 & 1.94 & .64 & 4,090 & 1.21 & .21 & 4,097 & 1.94 & 1.00 \\
\hline 4,200 & 1.95 & .65 & 4,198 & 1.21 & .22 & 4,203 & 1.94 & 1.00 \\
\hline 4,320 & 1.95 & .66 & 4,327 & 1.23 & .23 & 4,322 & 1.95 & 1.01 \\
\hline 4,440 & 1.95 & .66 & 4,438 & 1.21 & .23 & 4,442 & 1.91 & .99 \\
\hline 4,620 & 1.95 & .67 & 4,628 & 1.19 & .20 & 4,620 & 1.92 & .99 \\
\hline 4,820 & 2.01 & .70 & 4,823 & 1.26 & .24 & 4,816 & 2.02 & 1.04 \\
\hline 4,912 & 2.04 & .70 & 4,915 & 1.27 & .25 & 4,909 & 2.03 & 1.05 \\
\hline 5,030 & 2.03 & .72 & 5,032 & 1.26 & .25 & 5,024 & 2.01 & 1.05 \\
\hline 5,140 & 2.04 & .72 & 5,143 & 1.27 & .26 & 5,134 & 2.03 & 1.07 \\
\hline 5,508 & 2.07 & .73 & 5,502 & 1.30 & .28 & 5,511 & 2.06 & 1.10 \\
\hline 5,847 & 2.07 & .74 & 5,845 & 1.30 & .28 & 5,851 & 2.06 & 1.11 \\
\hline 6,086 & 2.06 & .76 & 6,084 & 1.26 & .25 & 6,088 & 2.02 & 1.08 \\
\hline 6,461 & 2.07 & .78 & 6,455 & 1.28 & .27 & 6,465 & 1.86 & 1.05 \\
\hline 7,093 & 1.96 & .78 & 7,089 & .99 & .08 & 7,090 & 1.80 & .81 \\
\hline 7,690 & 1.64 & .66 & 7,695 & .61 & -- & 7,686 & 1.30 & .47 \\
\hline 8,560 & 1.57 & .53 & 8,656 & .58 & -- & 8,563 & 1.34 & .44 \\
\hline 9,173 & 1.53 & .47 & 9,177 & .52 & -- & 9,169 & 1.31 & .41 \\
\hline 10,014 & 1.55 & .42 & 10,011 & .57 & -- & 10,016 & 1.38 & .47 \\
\hline 10,116 & 1.54 & .41 & 10,116 & .57 & -- & 10,116 & 1.39 & .47 \\
\hline
\end{tabular}


Appendix 2. Water-level drawdowns at observation wells during the Keyes multiple-well aquifer test, Milford, New Hampshire-Continued

\begin{tabular}{|c|c|c|c|c|c|c|c|c|}
\hline$\underset{(\min )}{t}$ & $\begin{array}{l}\text { PW1d } \\
\text { (ft) }\end{array}$ & $\begin{array}{l}\text { PW1s } \\
\text { (ft) }\end{array}$ & $\underset{(\min )}{t}$ & $\begin{array}{c}\text { PW2d } \\
\text { (ft) }\end{array}$ & $\begin{array}{c}\text { PW2s } \\
\text { (ft) }\end{array}$ & $\underset{(\min )}{t}$ & $\begin{array}{l}\text { PW3d } \\
\text { (ft) }\end{array}$ & $\begin{array}{c}\text { PW3s } \\
\text { (ft) }\end{array}$ \\
\hline 0 & 0.00 & 0.00 & 0 & 0.00 & 0.00 & 0 & 0.00 & 0.00 \\
\hline 5 & .00 & .00 & 6.0 & .35 & -- & 5 & .00 & .00 \\
\hline 1.0 & .00 & .00 & 7.0 & .75 & -- & 1.0 & .00 & .00 \\
\hline 1.5 & .01 & .00 & 8.0 & .95 & -- & 1.5 & .00 & .00 \\
\hline 2.0 & .02 & .00 & 9.0 & 1.15 & -- & 2.0 & .00 & .00 \\
\hline 3.0 & .08 & .01 & 10.0 & 1.15 & -- & 6.0 & .03 & .00 \\
\hline 4.0 & 0.18 & .01 & 12.0 & 1.60 & -- & 7.0 & .03 & .00 \\
\hline 5.0 & .29 & .01 & 14.0 & 1.75 & -- & 9.0 & .07 & .00 \\
\hline 6.0 & .45 & .01 & 16.0 & 2.75 & -- & 10.0 & .08 & .00 \\
\hline 7.0 & .61 & .01 & 18.0 & 2.90 & -- & 14.0 & .20 & .00 \\
\hline 8.0 & .77 & .01 & 20.0 & 2.95 & -- & 16.0 & .25 & .00 \\
\hline 9.0 & .97 & .01 & 22.0 & 2.90 & -- & 18.0 & .34 & .00 \\
\hline 10.0 & 1.08 & .01 & 24.0 & 3.05 & -- & 19.0 & .37 & .00 \\
\hline 12.0 & 1.38 & .01 & 26.0 & 3.07 & -- & 20.0 & .40 & .00 \\
\hline 14.0 & 1.64 & .02 & 28.0 & 3.11 & -- & 22.0 & .46 & .00 \\
\hline 16.0 & 1.85 & .02 & 30.0 & 3.09 & -- & 24.0 & .52 & .00 \\
\hline 18.0 & 2.03 & .02 & 35.0 & 3.13 & -- & 26.0 & .58 & .00 \\
\hline 20.0 & 2.19 & .02 & 40.0 & 3.16 & -- & 28.0 & .65 & .00 \\
\hline 22.0 & 2.31 & .02 & 45.0 & 3.20 & -- & 35.0 & .80 & .00 \\
\hline 24.0 & 2.43 & .02 & 50.0 & 3.23 & -- & 40.0 & .87 & .00 \\
\hline 26.0 & 2.52 & .02 & 55.0 & 3.23 & -- & 45.0 & .93 & .00 \\
\hline 28.0 & 2.59 & .02 & 60.0 & 3.22 & -- & 50.0 & .97 & .00 \\
\hline 30.0 & 2.66 & .02 & 70.0 & 3.23 & -- & 55.0 & .98 & .00 \\
\hline 35.0 & 2.76 & .02 & 80.0 & 3.25 & -- & 60.0 & .99 & .00 \\
\hline 40.0 & 2.82 & .02 & 90.0 & 3.25 & -- & 70.0 & 1.02 & .00 \\
\hline 45.0 & 2.87 & .02 & 100 & 3.28 & -- & 80.0 & 1.07 & .00 \\
\hline 50.0 & 2.89 & .02 & 120 & 3.24 & -- & 90.0 & 1.07 & .00 \\
\hline 55.0 & 2.92 & .02 & 140 & 3.27 & -- & 96.0 & 1.07 & .00 \\
\hline 60.0 & 2.93 & .02 & 160 & 3.25 & -- & 100 & 1.07 & .00 \\
\hline 70.0 & 2.93 & .03 & 180 & 3.25 & -- & 120 & 1.07 & .00 \\
\hline 80.0 & 2.96 & .03 & 200 & 3.26 & -- & 125 & 1.07 & .00 \\
\hline
\end{tabular}


Appendix 2. Water-level drawdowns at observation wells during the Keyes multiple-well aquifer test, Milford, New Hampshire-Continued

\begin{tabular}{|c|c|c|c|c|c|c|c|c|}
\hline$\underset{(\min )}{t}$ & $\begin{array}{l}\text { PW1d } \\
\text { (ft) }\end{array}$ & $\begin{array}{c}\text { PW1s } \\
\text { (ft) }\end{array}$ & $\underset{(\min )}{t}$ & $\begin{array}{c}\text { PW2d } \\
\text { (ft) }\end{array}$ & $\begin{array}{c}\text { PW2s } \\
\text { (ft) }\end{array}$ & $\underset{(\min )}{t}$ & $\begin{array}{c}\text { PW3d } \\
\text { (ft) }\end{array}$ & $\begin{array}{c}\text { PW3s } \\
\text { (ft) }\end{array}$ \\
\hline 90.0 & 2.97 & 0.03 & 240 & 3.22 & -- & 140 & 1.07 & 0.00 \\
\hline 100 & 2.99 & .03 & 300 & 3.25 & -- & 160 & 1.07 & .00 \\
\hline 120 & 2.99 & .03 & 349 & 3.25 & 0.16 & 180 & 1.07 & .00 \\
\hline 140 & 2.99 & .03 & 496 & 3.28 & .17 & 200 & 1.08 & .00 \\
\hline 160 & 2.99 & .03 & 649 & 3.30 & .18 & 205 & 1.07 & .00 \\
\hline 180 & 2.98 & .04 & 744 & 3.31 & .24 & 240 & 1.06 & .00 \\
\hline 200 & 2.97 & .04 & 850 & 3.29 & -- & 365 & 1.05 & .01 \\
\hline 240 & 2.91 & .04 & 1,195 & 3.28 & .23 & 507 & 1.07 & .00 \\
\hline 340 & 2.91 & .07 & 1,318 & 3.06 & .23 & 645 & 1.08 & .01 \\
\hline 501 & 2.94 & .08 & 1,440 & 3.22 & .24 & 751 & 1.09 & .01 \\
\hline 642 & 2.97 & .08 & 1,595 & 3.21 & .25 & 858 & 1.09 & .02 \\
\hline 747 & 2.97 & .09 & 1,710 & 3.22 & .25 & 1,188 & 1.07 & .03 \\
\hline 854 & 2.93 & .10 & 1,853 & 3.28 & .26 & 1,320 & 1.07 & .04 \\
\hline 1,182 & 2.92 & .13 & 1,971 & 3.31 & .26 & 1,443 & 1.05 & .04 \\
\hline 1,315 & 2.88 & .13 & 2,101 & 3.31 & .27 & 1,590 & 1.04 & .04 \\
\hline 1,438 & 2.85 & .13 & 2,224 & 3.31 & .28 & 1,711 & 1.05 & .05 \\
\hline 1,592 & 2.84 & .12 & 2,375 & 3.32 & .29 & 1,865 & 1.09 & .06 \\
\hline 1,709 & 2.85 & .13 & 2,647 & 3.34 & .31 & 1,967 & 1.10 & .06 \\
\hline 1,860 & 2.93 & .14 & 2,751 & 3.36 & .32 & 2,115 & 1.12 & .07 \\
\hline 1,975 & 2.96 & .15 & 2,865 & 3.36 & .32 & 2,231 & 1.11 & .07 \\
\hline 2,095 & 2.96 & .15 & 2,985 & 3.36 & .32 & 2,390 & 1.12 & .09 \\
\hline 2,227 & 2.96 & .16 & 3,437 & 3.37 & .36 & 2,649 & 1.13 & .09 \\
\hline 2,373 & 2.98 & .17 & 3,575 & 3.37 & .36 & 2,754 & 1.15 & .11 \\
\hline 2,645 & 3.00 & .18 & 3,702 & 3.38 & .37 & 2,872 & 1.15 & .11 \\
\hline 2,748 & 3.01 & .18 & 4,125 & 3.45 & .38 & 2,991 & 1.15 & .12 \\
\hline 2,868 & 3.02 & .19 & 4,225 & 3.46 & .40 & 3,439 & 1.17 & .13 \\
\hline 2,987 & 3.00 & .20 & 4,343 & 3.45 & .40 & 3,585 & 1.17 & .14 \\
\hline 3,429 & 3.03 & .23 & 4,465 & 3.42 & .40 & 3,700 & 1.17 & .15 \\
\hline 3,580 & 3.03 & .22 & 4,652 & 3.44 & .41 & 4,124 & 1.22 & .17 \\
\hline 3,699 & 3.03 & .23 & 4,789 & 3.47 & .43 & 4,228 & 1.22 & .17 \\
\hline 4,122 & 3.09 & .25 & 4,938 & 3.56 & .45 & 4,345 & 1.22 & .18 \\
\hline
\end{tabular}


Appendix 2. Water-level drawdowns at observation wells during the Keyes multiple-well aquifer test, Milford, New Hampshire-Continued

\begin{tabular}{|c|c|c|c|c|c|c|c|c|}
\hline$\underset{(\min )}{t}$ & $\begin{array}{c}\text { PW1d } \\
\text { (ft) }\end{array}$ & $\begin{array}{c}\text { PW1s } \\
\text { (ft) }\end{array}$ & $\underset{(\min )}{t}$ & $\begin{array}{c}\text { PW2d } \\
\text { (ft) }\end{array}$ & $\begin{array}{c}\text { PW2s } \\
\text { (ft) }\end{array}$ & $\underset{(\min )}{t}$ & $\begin{array}{c}\text { PW3d } \\
\text { (ft) }\end{array}$ & $\begin{array}{c}\text { PW3s } \\
\text { (ft) }\end{array}$ \\
\hline 4,223 & 3.10 & 0.27 & 5,059 & 3.55 & 0.45 & 4,467 & 1.21 & 0.17 \\
\hline 4,341 & 3.10 & .27 & 5,175 & 3.56 & .45 & 4,654 & 1.22 & .18 \\
\hline 4,463 & 3.07 & .28 & 5,532 & 3.57 & .46 & 4,790 & 1.23 & .19 \\
\hline 4,650 & 3.09 & .28 & 5,871 & 3.56 & .47 & 4,945 & 1.29 & .20 \\
\hline 4,786 & 3.11 & .29 & 6,123 & 3.53 & .48 & 5,064 & 1.29 & .20 \\
\hline 4,942 & 3.24 & .31 & 6,487 & 3.55 & .50 & 5,176 & 1.29 & .20 \\
\hline 5,062 & 3.23 & .31 & 7,134 & 3.34 & .45 & 5,535 & 1.31 & .21 \\
\hline 5,173 & 3.24 & .31 & 7,724 & 3.02 & .25 & 5,872 & 1.31 & .22 \\
\hline 5,531 & 3.26 & .33 & 8,591 & 3.00 & .09 & 6,132 & 1.30 & .23 \\
\hline 5,869 & 3.23 & .34 & 9,192 & 2.98 & .07 & 6,478 & 1.31 & .25 \\
\hline 6,127 & 3.20 & .36 & 10,025 & 3.02 & .07 & 7,141 & 1.22 & .27 \\
\hline 6,481 & 3.22 & .37 & 10,116 & 2.93 & .10 & 7,726 & 1.05 & .28 \\
\hline 7,139 & 3.01 & .33 & -- & -- & -. & 8,597 & 1.00 & .24 \\
\hline 7,724 & 2.64 & .13 & -- & -- & -- & 9,204 & .97 & .21 \\
\hline 8,591 & 2.62 & -- & -- & -- & -- & 10,030 & .98 & .17 \\
\hline 9,192 & 2.59 & -- & -- & -- & -- & -- & -- & -- \\
\hline 10,025 & 2.64 & -- & -- & -. & -- & -- & -- & -- \\
\hline 10,116 & 2.66 & -- & -- & -- & -- & -. & - & -. \\
\hline
\end{tabular}


APPENDIX 3. Water levels in riverbed piezometers and river stage during the Keyes multiple-well aquifer test, Milford, New Hampshire 
Appendix 3. Water levels in riverbed piezometers and river stage during the Keyes multiple-well aquifer test, Milford, New Hampshire

[Measurements relative to an arbitrary datum. Riverbed piezometers: Depth to water from top of piezometer casing. Stage: Depth to river stage from top of piezometer SKl casing. ft, foot; min, minute; --, no data]

\begin{tabular}{|c|c|c|c|c|}
\hline \multirow{2}{*}{$\begin{array}{c}\text { Time from start } \\
\text { of test } \\
(\min )\end{array}$} & \multicolumn{3}{|c|}{ Riverbed piezometers } & \multirow{2}{*}{$\begin{array}{c}\text { River } \\
\text { stage } \\
\text { (ft) }\end{array}$} \\
\hline & $\begin{array}{c}\text { SK1 } \\
(f t)\end{array}$ & $\begin{array}{c}\text { SK2 } \\
\text { (ft) }\end{array}$ & $\begin{array}{c}\text { SK3 } \\
\text { (ft) }\end{array}$ & \\
\hline 1.0 & 0.67 & 0.99 & 0.99 & 0.67 \\
\hline 2.0 & .67 & -- & -- & .67 \\
\hline 3.0 & .67 & -- & -- & .67 \\
\hline 4.0 & .68 & -- & -- & .67 \\
\hline 5.0 & .71 & -- & -- & .67 \\
\hline 6.0 & .71 & 1.00 & -- & .67 \\
\hline 7.0 & .72 & -- & - & .67 \\
\hline 8.0 & .74 & -- & -- & .67 \\
\hline 9.0 & .74 & -- & -- & .67 \\
\hline 10.0 & .74 & -- & -- & .67 \\
\hline 12.0 & .74 & -- & -- & .67 \\
\hline 14.0 & .74 & -- & -- & .67 \\
\hline 16.0 & .74 & -- & -- & .67 \\
\hline 18.0 & .74 & 1.02 & -- & .67 \\
\hline 20.0 & .74 & - & -- & .67 \\
\hline 22.0 & .74 & -- & -- & .67 \\
\hline 24.0 & .74 & -- & -- & .67 \\
\hline 26.0 & .75 & -- & 1.08 & .67 \\
\hline 28.0 & .75 & -- & -- & .67 \\
\hline 30.0 & .75 & 1.02 & -- & .67 \\
\hline 35.0 & .75 & -- & -- & .67 \\
\hline 40.0 & .75 & 1.05 & 1.08 & .67 \\
\hline 45.0 & .75 & -- & -. & .67 \\
\hline 50.0 & .75 & -- & -- & .67 \\
\hline 55.0 & .75 & -- & -- & .67 \\
\hline 60.0 & .75 & -- & - & .67 \\
\hline 70.0 & .75 & -- & -. & .67 \\
\hline 80.0 & .75 & 1.01 & 1.08 & .67 \\
\hline
\end{tabular}


Appendix 3. Water levels in riverbed piezometers and river stage during the Keyes multiple-well aquifer test, Milford, New Hampshire-Continued

\begin{tabular}{|c|c|c|c|c|}
\hline \multirow{2}{*}{$\begin{array}{l}\text { Time from start } \\
\text { of test } \\
\text { (min) }\end{array}$} & \multicolumn{3}{|c|}{ Riverbed piezometers } & \multirow{2}{*}{$\begin{array}{l}\text { River } \\
\text { stage } \\
\text { (ft) }\end{array}$} \\
\hline & $\begin{array}{l}\text { SK1 } \\
\text { (ft) }\end{array}$ & $\begin{array}{l}\text { SK2 } \\
\text { (ft) }\end{array}$ & $\begin{array}{l}\text { SK3 } \\
\text { (ft) }\end{array}$ & \\
\hline 90.0 & 0.75 & -- & -- & 0.67 \\
\hline 100 & .75 & -- & -- & .67 \\
\hline 120 & .75 & -- & -- & .67 \\
\hline 140 & .76 & 1.05 & -- & .67 \\
\hline 160 & .76 & -- & -- & .67 \\
\hline 180 & .78 & -- & 1.12 & .67 \\
\hline 200 & .80 & 1.07 & 1.13 & .69 \\
\hline 240 & .81 & 1.08 & 1.24 & .71 \\
\hline 311 & .82 & 1.07 & 1.15 & .72 \\
\hline 485 & .84 & 1.08 & 1.16 & .72 \\
\hline 615 & .77 & 1.00 & 1.09 & .65 \\
\hline 720 & .76 & -- & -- & .64 \\
\hline 823 & .78 & 1.00 & 1.08 & .65 \\
\hline 1,165 & .69 & 1.00 & .99 & .55 \\
\hline 1,295 & .68 & -- & .97 & .54 \\
\hline 1,420 & .57 & -. & .86 & .42 \\
\hline 1,575 & .54 & .77 & .84 & .40 \\
\hline 1,695 & .56 & .78 & .85 & .41 \\
\hline 1,830 & .64 & .87 & .94 & .50 \\
\hline 1,930 & .70 & .92 & 1.00 & .55 \\
\hline 2,070 & .69 & .91 & .98 & .54 \\
\hline 2,190 & .68 & .92 & .98 & .55 \\
\hline 2,354 & .73 & .94 & 1.00 & .59 \\
\hline 2,625 & .72 & -- & 1.03 & .58 \\
\hline 2,735 & .73 & .95 & 1.01 & .56 \\
\hline 2,855 & .73 & .95 & 1.01 & .56 \\
\hline 2,975 & .73 & .94 & 1.01 & .56 \\
\hline 3,405 & .73 & .95 & 1.02 & .66 \\
\hline 3,540 & .74 & .96 & 1.03 & .66 \\
\hline 3,715 & .76 & -- & -- & .67 \\
\hline
\end{tabular}


Appendix 3. Water levels in riverbed piezometers and river stage during the Keyes multiple-well aquifer test, Milford, New Hampshire-Continued

\begin{tabular}{|c|c|c|c|c|}
\hline \multirow{2}{*}{$\begin{array}{l}\text { Time from start } \\
\text { of test } \\
\text { (min) }\end{array}$} & \multicolumn{3}{|c|}{ Riverbed piezometers } & \multirow{2}{*}{$\begin{array}{c}\text { River } \\
\text { stage } \\
\text { (ft) }\end{array}$} \\
\hline & $\begin{array}{l}\text { SK1 } \\
\text { (ft) }\end{array}$ & $\begin{array}{c}\text { SK2 } \\
\text { (ft) }\end{array}$ & $\begin{array}{l}\text { SK3 } \\
\text { (ft) }\end{array}$ & \\
\hline 4,103 & 0.91 & -- & 1.18 & 0.73 \\
\hline 4,213 & .91 & 1.13 & 1.18 & .73 \\
\hline 4,333 & .92 & 1.13 & 1.20 & .74 \\
\hline 4,453 & .80 & 1.01 & 1.08 & .62 \\
\hline 4,635 & .83 & 1.04 & 1.10 & .65 \\
\hline 4,765 & .89 & 1.10 & 1.18 & .72 \\
\hline 4,915 & .89 & 1.11 & 1.18 & .74 \\
\hline 5,035 & .88 & 1.09 & 1.17 & .78 \\
\hline 5,145 & .91 & 1.14 & 1.20 & .73 \\
\hline 5,518 & .93 & -- & 1.22 & .74 \\
\hline 5,864 & .92 & 1.14 & 1.20 & .72 \\
\hline 6,102 & .83 & 1.05 & 1.12 & .63 \\
\hline 6,419 & .88 & 1.10 & 1.17 & .70 \\
\hline 7,120 & .46 & .64 & .70 & .23 \\
\hline
\end{tabular}


Appendix 3. Water levels in riverbed piezometers and river stage during the Keyes multiple-well aquifer test, Milford, New Hampshire-Continued

\begin{tabular}{|c|c|c|c|c|}
\hline \multirow{2}{*}{$\begin{array}{l}\text { Time from start } \\
\text { of test } \\
\text { (min) }\end{array}$} & \multicolumn{3}{|c|}{ Riverbed piezometers } & \multirow{2}{*}{$\begin{array}{c}\text { River } \\
\text { stage } \\
\text { (ft) }\end{array}$} \\
\hline & SP1 & $\begin{array}{c}\text { SP2 } \\
\text { (ft) }\end{array}$ & $\begin{array}{l}\text { SP3 } \\
\text { (ft) }\end{array}$ & \\
\hline 1.0 & 0.68 & 0.99 & 0.99 & 0.67 \\
\hline 2.0 & .57 & .99 & .99 & .67 \\
\hline 3.0 & .53 & -- & -- & .67 \\
\hline 4.0 & .55 & -- & -- & .67 \\
\hline 5.0 & .63 & -- & -. & .67 \\
\hline 6.0 & .65 & 1.00 & -- & .67 \\
\hline 7.0 & .72 & -- & -- & .67 \\
\hline 8.0 & .74 & - & -- & .67 \\
\hline 9.0 & .74 & -- & -- & .67 \\
\hline 10.0 & .74 & -- & -- & .67 \\
\hline 12.0 & .74 & -- & -- & .67 \\
\hline 14.0 & .74 & -- & -- & .67 \\
\hline 16.0 & .74 & -- & -- & 0.67 \\
\hline 18.0 & .74 & 1.02 & -- & .67 \\
\hline 20.0 & .74 & -- & -- & .67 \\
\hline 22.0 & .74 & -- & -- & .67 \\
\hline 24.0 & .74 & -- & -- & .67 \\
\hline 26.0 & .75 & -- & 1.08 & .67 \\
\hline 28.0 & .75 & -- & -- & .67 \\
\hline 30.0 & .75 & 1.02 & - & .67 \\
\hline 35.0 & .75 & -- & -- & .67 \\
\hline 40.0 & .75 & 1.05 & 1.08 & .67 \\
\hline 45.0 & .75 & -- & -- & .67 \\
\hline 50.0 & .75 & -- & -- & .67 \\
\hline 55.0 & .75 & -- & -- & .67 \\
\hline 60.0 & .75 & -- & -- & .67 \\
\hline 70.0 & .75 & -- & -- & .67 \\
\hline 80.0 & .75 & 1.01 & 1.08 & .67 \\
\hline 90.0 & .75 & -- & -- & .67 \\
\hline 100 & .75 & -- & -- & .67 \\
\hline
\end{tabular}


Appendix 3. Water levels in riverbed piezometers and river stage during the Keyes multiple-well aquifer test, Milford, New Hampshire-Continued

\begin{tabular}{|c|c|c|c|c|}
\hline \multirow{2}{*}{$\begin{array}{c}\text { Time from start } \\
\text { of test } \\
\text { (min) }\end{array}$} & \multicolumn{3}{|c|}{ Riverbed piezometers } & \multirow{2}{*}{$\begin{array}{c}\text { River } \\
\text { stage } \\
\text { (ft) }\end{array}$} \\
\hline & SP1 & $\begin{array}{c}\text { SP2 } \\
\text { (ft) }\end{array}$ & $\begin{array}{c}\text { SP3 } \\
\text { (ft) }\end{array}$ & \\
\hline 120 & 0.75 & -- & -- & 0.67 \\
\hline 140 & .76 & 1.05 & -- & .67 \\
\hline 160 & .76 & -- & -- & .67 \\
\hline 180 & .78 & - & 1.12 & .67 \\
\hline 200 & .80 & 1.07 & 1.13 & .69 \\
\hline 240 & .81 & 1.08 & 1.24 & .71 \\
\hline 374 & .85 & 1.25 & 1.13 & .72 \\
\hline 512 & .85 & 1.25 & 1.14 & .72 \\
\hline 1,182 & .68 & 1.25 & .95 & .55 \\
\hline 1,310 & .68 & 1.25 & .95 & .54 \\
\hline 1,435 & .57 & 1.25 & .84 & .42 \\
\hline 1,600 & .53 & 1.23 & .79 & .40 \\
\hline 1,702 & .55 & 1.22 & .80 & .41 \\
\hline 1,840 & .63 & 1.21 & .90 & .50 \\
\hline 1,977 & .65 & -- & -- & .55 \\
\hline 2,107 & .67 & 1.22 & -- & .54 \\
\hline 2,384 & .69 & 1.21 & .97 & .59 \\
\hline 2,640 & .71 & 1.22 & .96 & .58 \\
\hline 2,745 & .70 & 1.22 & .95 & .58 \\
\hline 2,865 & .71 & 1.22 & .97 & .56 \\
\hline 2,983 & .71 & 1.22 & .97 & .56 \\
\hline 3,577 & .72 & 1.25 & .97 & .66 \\
\hline 4,120 & .87 & 1.27 & 1.14 & .73 \\
\hline 4,223 & .88 & 1.28 & 1.15 & .73 \\
\hline 4,342 & .89 & 1.30 & 1.16 & .74 \\
\hline 4,462 & .76 & 1.30 & 1.02 & .62 \\
\hline 4,641 & .80 & 1.30 & 1.05 & .65 \\
\hline 4,770 & .86 & 1.31 & 1.11 & .72 \\
\hline 4,920 & .86 & 1.31 & 1.12 & .74 \\
\hline 5,045 & .85 & 1.34 & 1.10 & .78 \\
\hline
\end{tabular}


Appendix 3. Water levels in riverbed piezometers and river stage during the Keyes multiple-well aquifer test, Milford, New Hampshire-Continued

\begin{tabular}{|c|c|c|c|c|}
\hline \multirow{2}{*}{$\begin{array}{c}\text { Time from start } \\
\text { of test } \\
\text { (min) }\end{array}$} & \multicolumn{3}{|c|}{ Riverbed piezometers } & \multirow{2}{*}{$\begin{array}{c}\text { River } \\
\text { stage } \\
\text { (ft) }\end{array}$} \\
\hline & SP1 & $\begin{array}{c}\text { SP2 } \\
\text { (ft) }\end{array}$ & $\begin{array}{c}\text { SP3 } \\
\text { (ft) }\end{array}$ & \\
\hline 5,156 & 0.88 & 1.33 & 1.13 & 0.73 \\
\hline 5,524 & .91 & 1.36 & 1.16 & .74 \\
\hline 5,867 & .89 & 1.36 & 1.14 & .72 \\
\hline 6,130 & .82 & 1.37 & 1.06 & .63 \\
\hline 6,425 & .87 & 1.37 & 1.11 & .70 \\
\hline 7,132 & .39 & 1.25 & .63 & .23 \\
\hline
\end{tabular}


APPENDIX 4. Water-level recovery at observation wells after the Keyes multiple-well aquifer test, Milford, New Hampshire 
Appendix 4. Water-level recovery at observation wells after the Keyes multiple-well aquifer test, Milford, New Hampshire

[min, minute; ft, foot]

\begin{tabular}{|c|c|c|c|c|c|c|c|c|c|c|}
\hline$\underset{(\min )}{t}$ & $\begin{array}{c}\text { KWOBS } \\
\text { (ft) }\end{array}$ & $\underset{(\min )}{t}$ & $\begin{array}{c}\text { KW2d } \\
\text { (ft) }\end{array}$ & $\begin{array}{c}\text { KW2s } \\
\text { (ft) }\end{array}$ & $\underset{(\min )}{t}$ & $\begin{array}{c}\text { KW3d } \\
\text { (ft) }\end{array}$ & $\begin{array}{c}\text { KW3s } \\
\text { (ft) }\end{array}$ & $\underset{(\min )}{t}$ & $\begin{array}{c}\text { KW4d } \\
\text { (ft) }\end{array}$ & $\begin{array}{c}\text { KW4s } \\
\text { (ft) }\end{array}$ \\
\hline 0.0 & 21.10 & 0.0 & 14.38 & 12.97 & 0.0 & 11.83 & 11.67 & 0.0 & 11.07 & 10.13 \\
\hline 1.5 & 20.90 & 1.0 & 14.38 & 12.97 & 1.0 & 11.83 & 11.67 & 1.0 & 11.07 & 10.13 \\
\hline 3.8 & 20.75 & 2.0 & 14.38 & 12.96 & 2.0 & 11.83 & 11.66 & 2.0 & 11.07 & 10.13 \\
\hline 5.2 & 20.62 & 3.0 & 14.38 & 12.96 & 3.0 & 11.83 & 11.66 & 3.0 & 11.07 & 10.13 \\
\hline 6.1 & 20.62 & 4.0 & 14.37 & 12.96 & 4.0 & 11.80 & 11.66 & 4.0 & 11.02 & 10.12 \\
\hline 9.2 & 20.35 & 7.0 & 14.31 & 12.94 & 7.0 & 11.54 & 11.65 & 7.0 & 10.67 & 10.04 \\
\hline 10.6 & 20.30 & 8.0 & 14.27 & 12.94 & 8.0 & 11.45 & 11.65 & 8.0 & 10.54 & 10.02 \\
\hline 11.5 & 20.17 & 9.0 & 14.22 & 12.93 & 9.0 & 11.36 & 11.65 & 9.0 & 10.43 & 9.98 \\
\hline 12.3 & 20.05 & 10.0 & 14.17 & 12.93 & 10.0 & 11.29 & 11.64 & 10.0 & 10.29 & 9.97 \\
\hline 13.7 & 19.93 & 11.0 & 14.12 & 12.93 & 12.0 & 11.18 & 11.64 & 12.0 & 10.15 & 9.93 \\
\hline 15.2 & 19.90 & 12.0 & 14.07 & 12.93 & 14.0 & 11.10 & 11.64 & 14.0 & 10.03 & 9.91 \\
\hline 17.0 & 19.80 & 14.0 & 13.97 & 12.92 & 16.0 & 11.05 & 11.63 & 16.0 & 9.94 & 9.89 \\
\hline 26.0 & 19.00 & 19.0 & 13.73 & 12.91 & 25.0 & 10.94 & 11.63 & 26.0 & 9.75 & 9.85 \\
\hline 28.0 & 18.86 & 20.0 & 13.68 & 12.91 & 26.0 & 10.94 & 11.63 & 28.0 & 9.72 & 9.84 \\
\hline 29.6 & 18.80 & 21.0 & 13.64 & 12.91 & 27.0 & 10.93 & 11.62 & 30.0 & 9.71 & 9.83 \\
\hline 32.5 & 18.57 & 22.0 & 13.61 & 12.91 & 28.0 & 10.93 & 11.62 & 35.0 & 9.68 & 9.81 \\
\hline 35.0 & 18.48 & 23.0 & 13.57 & 12.90 & 30.0 & 10.92 & 11.62 & 40.0 & 9.65 & 9.80 \\
\hline 40.7 & 18.07 & 24.0 & 13.54 & 12.90 & 31.0 & 10.91 & 11.62 & 45.0 & 9.64 & 9.79 \\
\hline 45.7 & 17.75 & 25.0 & 13.50 & 12.90 & 32.0 & 10.91 & 11.62 & 50.0 & 9.62 & 9.78 \\
\hline 50.0 & 17.51 & 26.0 & 13.48 & 12.90 & 33.0 & 10.90 & 11.62 & 55.0 & 9.60 & 9.78 \\
\hline 55.2 & 17.28 & 27.0 & 13.44 & 12.90 & 34.0 & 10.90 & 11.62 & 60.0 & 9.60 & 9.77 \\
\hline
\end{tabular}


Appendix 4. Water-level recovery at observation wells after the Keyes multiple-well aquifer test, Milford, New HampshireContinued

\begin{tabular}{|c|c|c|c|c|c|c|c|c|c|c|}
\hline$\underset{(\min )}{t}$ & $\begin{array}{c}\text { KWOBS } \\
\text { (ft) }\end{array}$ & $\underset{(\mathrm{min})}{t}$ & $\begin{array}{c}\text { KW2d } \\
\text { (ft) }\end{array}$ & $\begin{array}{c}\text { KW2s } \\
\text { (ft) }\end{array}$ & $\underset{(\min )}{t}$ & $\begin{array}{c}\text { KW3d } \\
\text { (ft) }\end{array}$ & $\begin{array}{c}\text { KW3s } \\
\text { (ft) }\end{array}$ & $\underset{(m i n)}{t}$ & $\begin{array}{c}\text { KW4d } \\
\text { (ft) }\end{array}$ & $\begin{array}{c}\text { KW4s } \\
\text { (ft) }\end{array}$ \\
\hline 60.0 & 17.08 & 28.0 & 13.42 & 12.90 & 35.0 & 10.90 & 11.62 & 65.0 & 9.60 & 9.76 \\
\hline 65.0 & 16.80 & 29.0 & 13.38 & 12.90 & 36.0 & 10.90 & 11.62 & 70.0 & 9.60 & 9.76 \\
\hline 70.0 & 16.62 & 30.0 & 13.37 & 12.89 & 37.0 & 10.90 & 11.62 & 80.0 & 9.59 & 9.75 \\
\hline 79.0 & 16.20 & 32.0 & 13.32 & 12.89 & 38.0 & 10.89 & 11.62 & 90.0 & 9.58 & 9.74 \\
\hline 90.0 & 15.58 & 35.0 & 13.27 & 12.89 & 39.0 & 10.89 & 11.62 & 100 & 9.57 & 9.73 \\
\hline 100 & 15.50 & 37.0 & 13.23 & 12.89 & 40.0 & 10.88 & 11.61 & 120 & 9.56 & 9.72 \\
\hline 120 & 14.95 & 39.0 & 13.20 & 12.89 & 45.0 & 10.88 & 11.61 & 140 & 9.54 & 9.70 \\
\hline 140 & 14.55 & 40.0 & 13.18 & 12.89 & 50.0 & 10.88 & 11.61 & 160 & 9.54 & 9.70 \\
\hline 160 & 14.26 & 45.0 & 13.13 & 12.89 & 55.0 & 10.87 & 11.61 & 180 & 9.53 & 9.69 \\
\hline 180 & 13.90 & 50.0 & 13.08 & 12.88 & 60.0 & 10.87 & 11.61 & 220 & 9.53 & 9.68 \\
\hline 220 & 13.54 & 55.0 & 13.05 & 12.88 & 65.0 & 10.87 & 11.61 & 1,491 & 9.34 & 9.41 \\
\hline \multirow[t]{12}{*}{1,415} & 12.56 & 60.0 & 13.03 & 12.88 & 70.0 & 10.86 & 11.61 & & & \\
\hline & & 65.0 & 13.00 & 12.87 & 80.0 & 10.86 & 11.61 & & & \\
\hline & & 70.0 & 12.99 & 12.87 & 90.0 & 10.85 & 11.61 & & & \\
\hline & & 80.0 & 12.96 & 12.86 & 100 & 10.85 & 11.61 & & & \\
\hline & & 90.0 & 12.94 & 12.85 & 120 & 10.84 & 11.61 & & & \\
\hline & & 100 & 12.93 & 12.84 & 140 & 10.85 & 11.61 & & & \\
\hline & & 121 & 12.90 & 12.83 & 160 & 10.85 & 11.61 & & & \\
\hline & & 140 & 12.88 & 12.82 & 180 & 10.85 & 11.61 & & & \\
\hline & & 160 & 12.87 & 12.81 & 220 & 10.85 & 11.61 & & & \\
\hline & & 180 & 12.87 & 12.79 & 1,400 & 10.80 & 11.63 & & & \\
\hline & & 220 & 12.84 & 12.77 & & & & & & \\
\hline & & 1,394 & 12.61 & 12.47 & & & & & & \\
\hline
\end{tabular}


Appendix 4. Water-level recovery at observation wells after the Keyes multiple-well aquifer test-Continued

\begin{tabular}{|c|c|c|c|c|c|}
\hline$\underset{(\min )}{t}$ & $\begin{array}{c}\text { PW1d } \\
\text { (ft) }\end{array}$ & $\underset{(\min )}{t}$ & $\begin{array}{l}\text { PW2d } \\
\text { (ft) }\end{array}$ & $\underset{(\min )}{t}$ & $\begin{array}{c}\text { PW3d } \\
\text { (ft) }\end{array}$ \\
\hline 0.0 & 20.76 & 0.0 & 21.80 & 0.0 & 20.68 \\
\hline .5 & 20.75 & .5 & 21.85 & .5 & 20.68 \\
\hline 1.0 & 20.75 & 1.0 & 21.80 & 1.0 & 20.68 \\
\hline 1.5 & 20.75 & 1.5 & 21.80 & 1.5 & 20.69 \\
\hline 2.0 & 20.75 & 2.0 & 21.80 & 2.0 & 20.69 \\
\hline 3.0 & 20.75 & 3.0 & 21.80 & 3.0 & 20.69 \\
\hline 4.0 & 20.72 & 4.0 & 21.80 & 4.0 & 20.68 \\
\hline 5.0 & 20.65 & 5.0 & 21.75 & 5.0 & 20.67 \\
\hline 6.0 & 20.56 & 6.0 & 21.65 & 6.0 & 20.67 \\
\hline 7.0 & 20.45 & 7.0 & 21.50 & 7.0 & 20.67 \\
\hline 8.0 & 20.31 & 8.0 & 21.35 & 8.0 & 20.66 \\
\hline 9.0 & 20.17 & 9.0 & 21.22 & 9.0 & 20.65 \\
\hline 10.0 & 20.02 & 10.0 & 20.98 & 10.0 & 20.64 \\
\hline 12.0 & 19.74 & 12.0 & 20.82 & 12.0 & 20.56 \\
\hline 14.0 & 19.47 & 14.0 & 20.58 & 14.0 & 20.52 \\
\hline 16.0 & 19.25 & 16.0 & 20.48 & 16.0 & 20.47 \\
\hline 18.0 & 19.06 & 18.0 & 20.37 & 18.0 & 20.41 \\
\hline 20.0 & 18.88 & 20.0 & 20.17 & 20.0 & 20.35 \\
\hline 21.0 & 18.80 & 22.0 & 20.19 & 22.0 & 20.31 \\
\hline 22.0 & 18.72 & 24.0 & 20.19 & 24.0 & 20.23 \\
\hline 23.0 & 18.66 & 26.0 & 20.17 & 26.0 & 20.20 \\
\hline 24.0 & 18.61 & 28.0 & 20.13 & 28.0 & 20.14 \\
\hline 25.0 & 18.55 & 31.0 & 20.07 & 31.0 & 20.06 \\
\hline 26.0 & 18.50 & 33.0 & 20.06 & 33.0 & 20.01 \\
\hline 27.0 & 18.45 & 35.0 & 20.04 & 35.0 & 19.99 \\
\hline 28.0 & 18.42 & 37.0 & 20.01 & 38.0 & 19.95 \\
\hline 29.0 & 18.38 & 39.0 & 20.02 & 40.0 & 19.91 \\
\hline 31.0 & 18.32 & 43.0 & 20.00 & 45.0 & 19.84 \\
\hline 33.0 & 18.27 & 45.0 & 20.00 & 50.0 & 19.80 \\
\hline 35.0 & 18.23 & 50.0 & 19.99 & 55.0 & 19.78 \\
\hline 37.0 & 18.19 & 55.0 & 19.96 & 60.0 & 19.75 \\
\hline
\end{tabular}


Appendix 4. Water-level recovery at observation wells after the Keyes multiple-well aquifer test-Continued

\begin{tabular}{cccccc}
\hline $\begin{array}{c}\boldsymbol{t} \\
(\mathbf{m i n})\end{array}$ & $\begin{array}{c}\text { PW1d } \\
(\mathbf{f t})\end{array}$ & $\begin{array}{c}\boldsymbol{t} \\
(\mathbf{m i n})\end{array}$ & $\begin{array}{c}\text { PW2d } \\
(\mathbf{f t})\end{array}$ & $\begin{array}{c}\boldsymbol{t} \\
(\mathbf{m i n})\end{array}$ & $\begin{array}{c}\text { PW3d } \\
(\mathbf{f t})\end{array}$ \\
\hline 39.0 & 18.16 & 60.0 & 19.96 & 65.0 & 19.72 \\
45.0 & 18.10 & 65.0 & 19.95 & 70.0 & 19.70 \\
50.0 & 18.07 & 70.0 & 19.94 & 80.0 & 19.67 \\
55.0 & 18.03 & 80.0 & 19.94 & 90.0 & 19.67 \\
60.0 & 18.02 & 90.0 & 19.92 & 100 & 19.66 \\
65.0 & 18.02 & 100 & 19.92 & 120 & 19.66 \\
70.0 & 18.01 & 120 & 19.92 & 140 & 19.67 \\
80.0 & 18.00 & 140 & 19.90 & 160 & 19.67 \\
90.0 & 17.98 & 160 & 19.89 & 180 & 19.66 \\
100 & 17.97 & 180 & 19.90 & 220 & 19.72 \\
120 & 17.96 & 220 & 19.95 & 1,382 & 19.61 \\
140 & 17.95 & 1,380 & 19.82 & & \\
160 & 17.95 & & & & \\
180 & 17.94 & & & & \\
220 & 17.94 & & & & \\
1,378 & 17.78 & & & & \\
\hline
\end{tabular}


APPENDIX 5. Water-quality constituents measured at the Keyes well during the multiple-well aquifer test, Milford, New Hampshire 
Appendix 5. Water-quality constituents measured at the Keyes well during the multiple-well aquifer test, Milford, New Hampshire

[ $\mu \mathrm{S} / \mathrm{cm}$, microsiemen per centimeter at 25 degrees Celsius; --, no data]

\begin{tabular}{|c|c|c|c|}
\hline $\begin{array}{l}\text { Minutes from } \\
\text { start of aquifer } \\
\text { test }\end{array}$ & $\begin{array}{c}\text { Specific } \\
\text { conductance } \\
(\mu \mathrm{S} / \mathrm{cm})\end{array}$ & $\underset{\text { (units) }}{\mathbf{p H}}$ & $\begin{array}{c}\text { Temperature } \\
\text { (degrees } \\
\text { Celsius) }\end{array}$ \\
\hline 16 & 220 & -- & -- \\
\hline 18 & -- & -- & 12.5 \\
\hline 24 & 250 & 7.08 & 12.4 \\
\hline 35 & 250 & 7.22 & 12.3 \\
\hline 43 & 250 & 7.26 & 12.1 \\
\hline 55 & 250 & 7.26 & 12.1 \\
\hline 60 & 250 & 7.30 & 12.0 \\
\hline 70 & 250 & 7.10 & 12.0 \\
\hline 80 & 250 & 7.26 & 11.9 \\
\hline 90 & 250 & 7.50 & 11.9 \\
\hline 100 & 250 & 7.37 & 11.9 \\
\hline 120 & 250 & 7.56 & 11.8 \\
\hline 140 & 240 & 6.96 & 11.8 \\
\hline 160 & 250 & 6.87 & 11.8 \\
\hline 180 & 250 & 6.88 & 11.7 \\
\hline 200 & 250 & 6.87 & 11.7 \\
\hline 240 & 260 & 6.77 & 11.6 \\
\hline 300 & 260 & 6.80 & 11.6 \\
\hline 480 & 280 & 6.72 & 11.5 \\
\hline 590 & 295 & 6.60 & 11.5 \\
\hline 700 & 295 & 6.58 & 11.4 \\
\hline 815 & 300 & 6.54 & 11.3 \\
\hline 1,080 & 300 & 6.68 & 11.7 \\
\hline 1,285 & 300 & 6.55 & 11.5 \\
\hline 1,405 & 300 & 6.53 & 11.5 \\
\hline 1,545 & 300 & 6.57 & 11.6 \\
\hline 1,672 & 305 & 6.61 & 11.7 \\
\hline 1,799 & 305 & 6.60 & 11.5 \\
\hline 1,902 & 310 & 6.60 & 11.4 \\
\hline
\end{tabular}


Appendix 5. Water-quality constituents measured at the Keyes well during the multiple-well aquifer test, Milford, New Hampshire

\begin{tabular}{|c|c|c|c|}
\hline $\begin{array}{l}\text { Minutes from } \\
\text { start of aquifer } \\
\text { test }\end{array}$ & $\begin{array}{c}\text { Specific } \\
\text { conductance } \\
(\mu \mathrm{S} / \mathrm{cm})\end{array}$ & $\underset{\text { (units) }}{\mathbf{p H}}$ & $\begin{array}{c}\text { Temperature } \\
\text { (degrees } \\
\text { Celsius) }\end{array}$ \\
\hline 1,920 & 310 & 6.55 & 11.4 \\
\hline 2,040 & 310 & 6.63 & 11.3 \\
\hline 2,200 & 305 & 6.53 & 11.4 \\
\hline 2,605 & 310 & 6.54 & 11.7 \\
\hline 2,720 & 300 & 6.54 & 11.2 \\
\hline 2,840 & 300 & 6.46 & 11.3 \\
\hline 2,965 & 303 & 6.45 & 11.2 \\
\hline 3,370 & 300 & 6.50 & 11.4 \\
\hline 3,520 & 300 & 6.39 & 11.3 \\
\hline 3,665 & 295 & 6.45 & 11.2 \\
\hline 4,080 & 290 & 6.48 & 11.5 \\
\hline 4,200 & 300 & 6.45 & 11.3 \\
\hline 4,320 & 305 & 6.45 & 11.2 \\
\hline 4,440 & 295 & 6.40 & 11.2 \\
\hline 4,620 & 310 & 6.45 & 11.3 \\
\hline 4,805 & 305 & 6.49 & 11.2 \\
\hline 4,895 & 310 & 6.47 & 11.3 \\
\hline 5,010 & 310 & 6.46 & 11.3 \\
\hline 5,115 & 310 & 6.42 & 11.3 \\
\hline 5,495 & 300 & 6.40 & 11.4 \\
\hline 5,840 & 300 & 6.42 & 11.3 \\
\hline 6,070 & 295 & 6.53 & 11.4 \\
\hline 6,440 & 300 & 6.35 & 11.3 \\
\hline 7,075 & 290 & 6.42 & 11.4 \\
\hline 7,675 & 300 & 6.48 & 11.5 \\
\hline 8,535 & 295 & 6.42 & 11.3 \\
\hline 9,160 & 300 & 6.54 & 11.5 \\
\hline 10,116 & 290 & 6.43 & 11.4 \\
\hline
\end{tabular}




\section{APPENDIX 6. Volatile organic chemicals sampled for and detection limits of analysis}


Appendix 6. Volatile organic chemicals sampled for at the Keyes well and detection limits of analysis [ $\mu \mathrm{g} / \mathrm{L}$, microgram per liter]

\begin{tabular}{|c|c|c|c|}
\hline Constituent & $\begin{array}{c}\text { Detection } \\
\text { limit } \\
(\mu g / L)\end{array}$ & Constituent & $\begin{array}{c}\text { Detection } \\
\text { limit } \\
(\mu g / L)\end{array}$ \\
\hline Acetone & 50 & Tetrahydrofuran & 36 \\
\hline 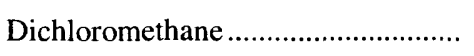 & 4 & 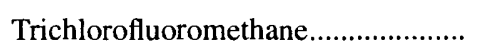 & 5 \\
\hline 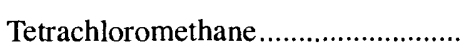 & 5 & 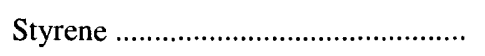 & .9 \\
\hline 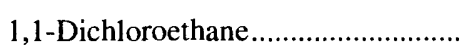 & .5 & Methyl t-butyl ether .............................. & 1.7 \\
\hline 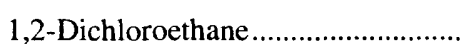 & .8 & 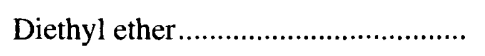 & 3.3 \\
\hline 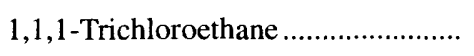 & .4 & Methyl ethyl ketone .............................. & 28 \\
\hline 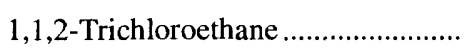 & 5 & Methyl isobutyl ketone......................... & 4.4 \\
\hline 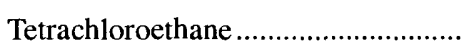 & 1.2 & 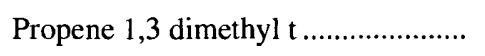 & 5 \\
\hline 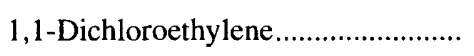 & .4 & Trichlorotrifluoroethane ........................ & 1.4 \\
\hline cis \& trans 1,2 -Dichloroethylene ..... & .7 & 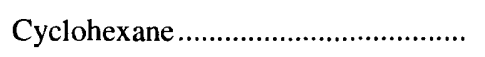 & 5 \\
\hline Trichloroethylene ............................. & .6 & 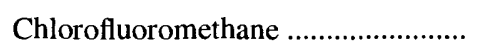 & 5 \\
\hline 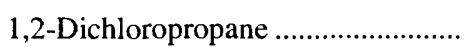 & 5 & Dichlorodifluoromethane .................... & 5 \\
\hline 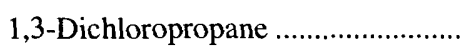 & 5 & Dichlorotrifluoroethane ...................... & 5 \\
\hline 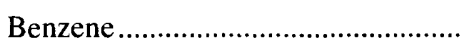 & .5 & Trihalomethanes: & \\
\hline 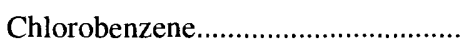 & 1 & 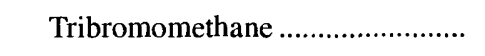 & 5 \\
\hline 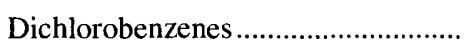 & 9.6 & 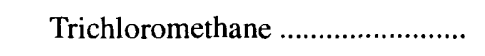 & .5 \\
\hline 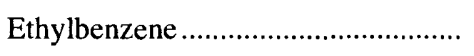 & 1.1 & Dichlorobromomethane ................. & 5 \\
\hline 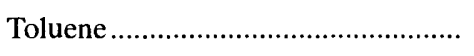 & 1.7 & Chlorodibromomethane................. & 5 \\
\hline 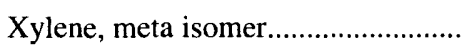 & 1.3 & Chloroethylene (Vinyl chloride) ...... & 2.4 \\
\hline Xylenes, ortho and para........................ & 1.2 & $1,1,2,2$ Tetrachloroethene .................... & 5 \\
\hline Camphor & 66 & 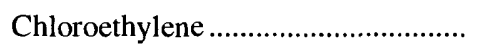 & 5 \\
\hline
\end{tabular}



APPENDIX 7. Volatile organic chemical analysis of water from the Keyes well during the multiple-well aquifer test, Milford, New Hampshire 
Appendix 7. Volatile organic chemical analysis of water from the Keyes well during the multiple-well aquifer test, Milford, New Hampshire

[Time: number shown is minutes from start of aquifer test. min, minute; $\mathrm{mg} / \mathrm{L}$, milligram per liter; NA, not applicable; --, indicates no detection]

\begin{tabular}{|c|c|c|c|}
\hline $\begin{array}{l}\text { Time } \\
\text { (min) }\end{array}$ & & $\begin{array}{l}\text { Concentration } \\
\text { and organic compound } \\
(\mathrm{mg} / \mathrm{L})\end{array}$ & Notes \\
\hline 28 & -- & -- & NA \\
\hline 39 & -- & -- & NA \\
\hline 60 & -- & -- & NA \\
\hline 120 & -- & -- & NA \\
\hline 180 & -- & -- & NA \\
\hline 240 & - & -- & NA \\
\hline 450 & -- & -- & NA \\
\hline 720 & -- & -- & NA \\
\hline 1,440 & $\begin{array}{l}1.7 \\
70 \\
2.14\end{array}$ & $\begin{array}{l}\text { 1,2-Dichloroethane } \\
\text { Benzene } \\
\text { Xylenes (ortho \& para) }\end{array}$ & NA \\
\hline 1,900 & $\begin{array}{c}9.34 \\
4.0 \\
51.8 \\
1,460 \\
596\end{array}$ & $\begin{array}{l}\text { 1,2-Dichloroethane } \\
\text { Toluene } \\
\text { Xylenes (ortho \& para) } \\
\text { Acetone } \\
\text { Tetrahydrofuran }\end{array}$ & $\left({ }^{a}\right)$ \\
\hline 2,325 & $\begin{array}{l}5.79 \\
250 \\
15.8 \\
701\end{array}$ & $\begin{array}{l}\text { 1,2-Dichloroethane } \\
\text { Benzene } \\
\text { Xylenes (ortho \& para) } \\
\text { Acetone }\end{array}$ & $\left({ }^{a}\right)$ \\
\hline 2,850 & $\begin{array}{c}8.50 \\
152 \\
19.5\end{array}$ & $\begin{array}{l}\text { 1,2-Dichloroethane } \\
\text { Benzene } \\
\text { Xylenes (ortho \& para) }\end{array}$ & $\left({ }^{a}, b\right)$ \\
\hline 3,360 & 12.5 & 1,2-Dichloroethane & $\left.{ }^{b}\right)$ \\
\hline 4,320 & 13.8 & 1,2-Dichloroethane & $(a, b)$ \\
\hline 4,800 & 14.8 & 1,2-Dichloroethane & $\left({ }^{b}\right)$ \\
\hline 5,118 & 14.8 & 1,2-Dichloroethane & $(\mathrm{b})$ \\
\hline 5,850 & 15.4 & 1,2-Dichloroethane & $\left(^{b}\right)$ \\
\hline 6,450 & 14.9 & 1,2-Dichloroethane & $(\mathrm{b})$ \\
\hline 8,550 & 13.1 & 1,2-Dichloroethane & $(\mathrm{b})$ \\
\hline 11,520 & 12.0 & 1,2-Dichloroethane & $\left({ }^{b}\right)$ \\
\hline
\end{tabular}

${ }^{\mathrm{a}}$ Indicates hydrocarbons present indicative of gasoline.

bindicates unknown gaschromatograph peak present. 

APPENDIX 8. Plots of slug test data response at observation wells, Milford, New Hampshire 
(A)

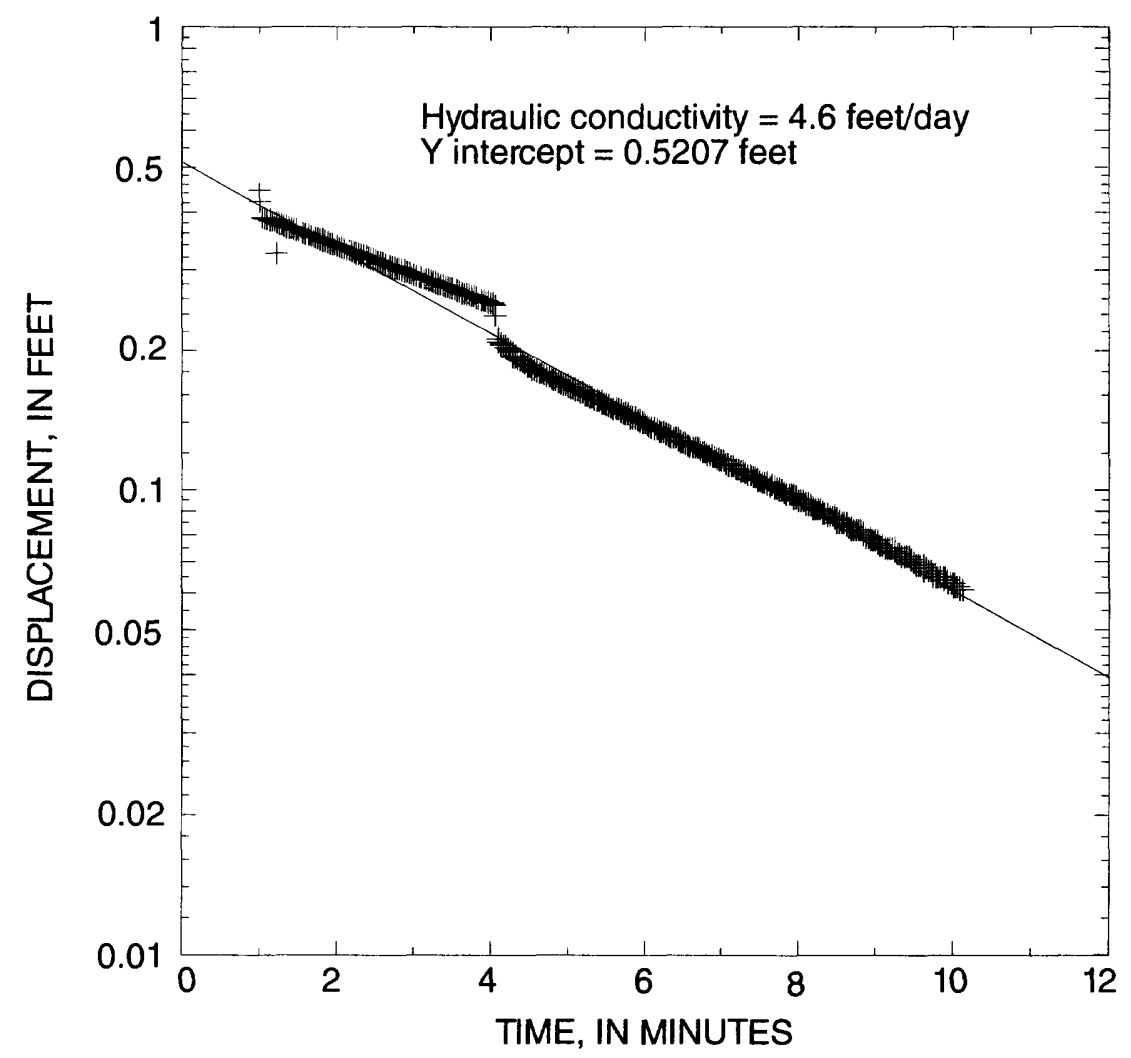

(B)

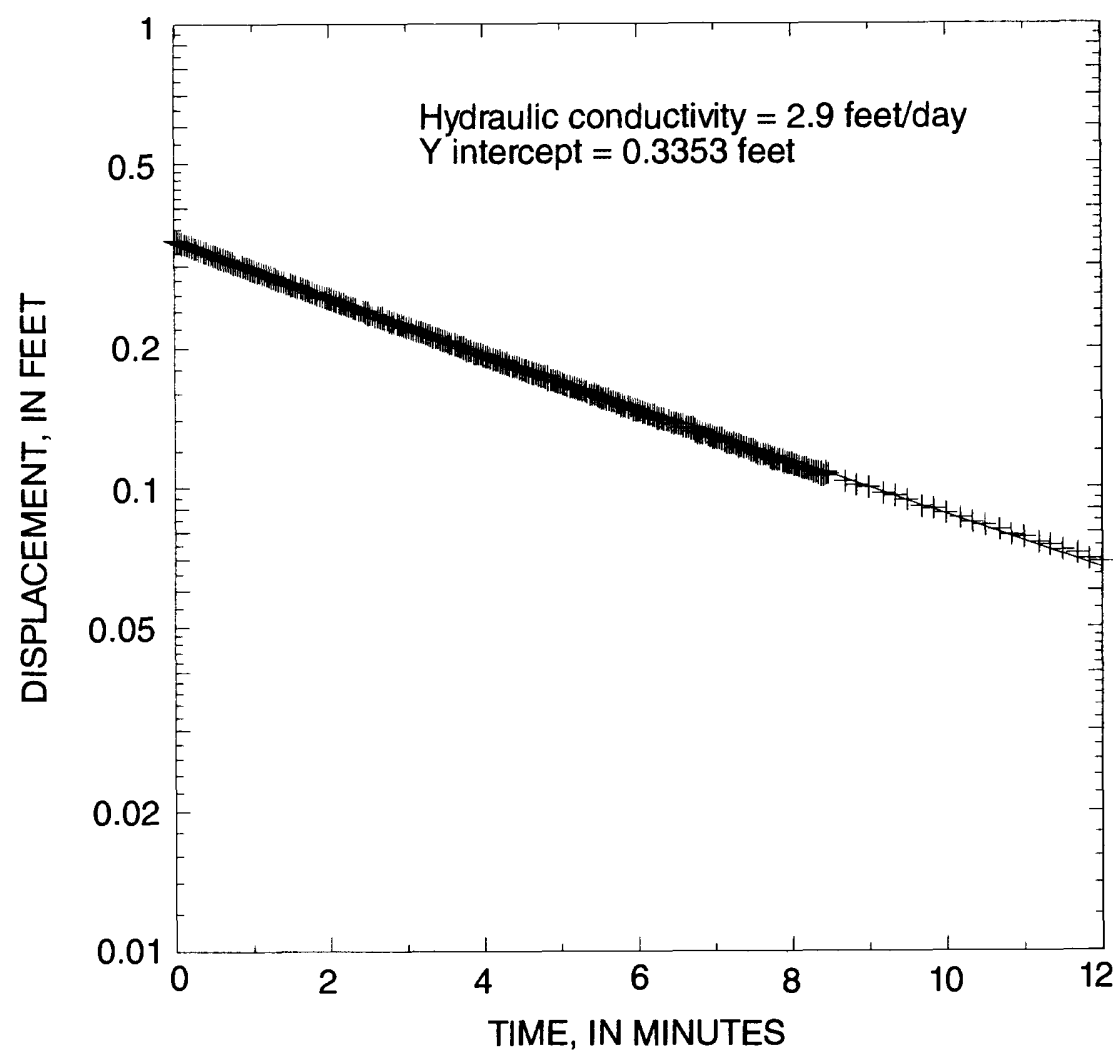

Appendix 8. Plots of slug test data response at KW1 $(A)$ forward, and $(B)$ reverse, Milford, New Hampshire. 
(A)

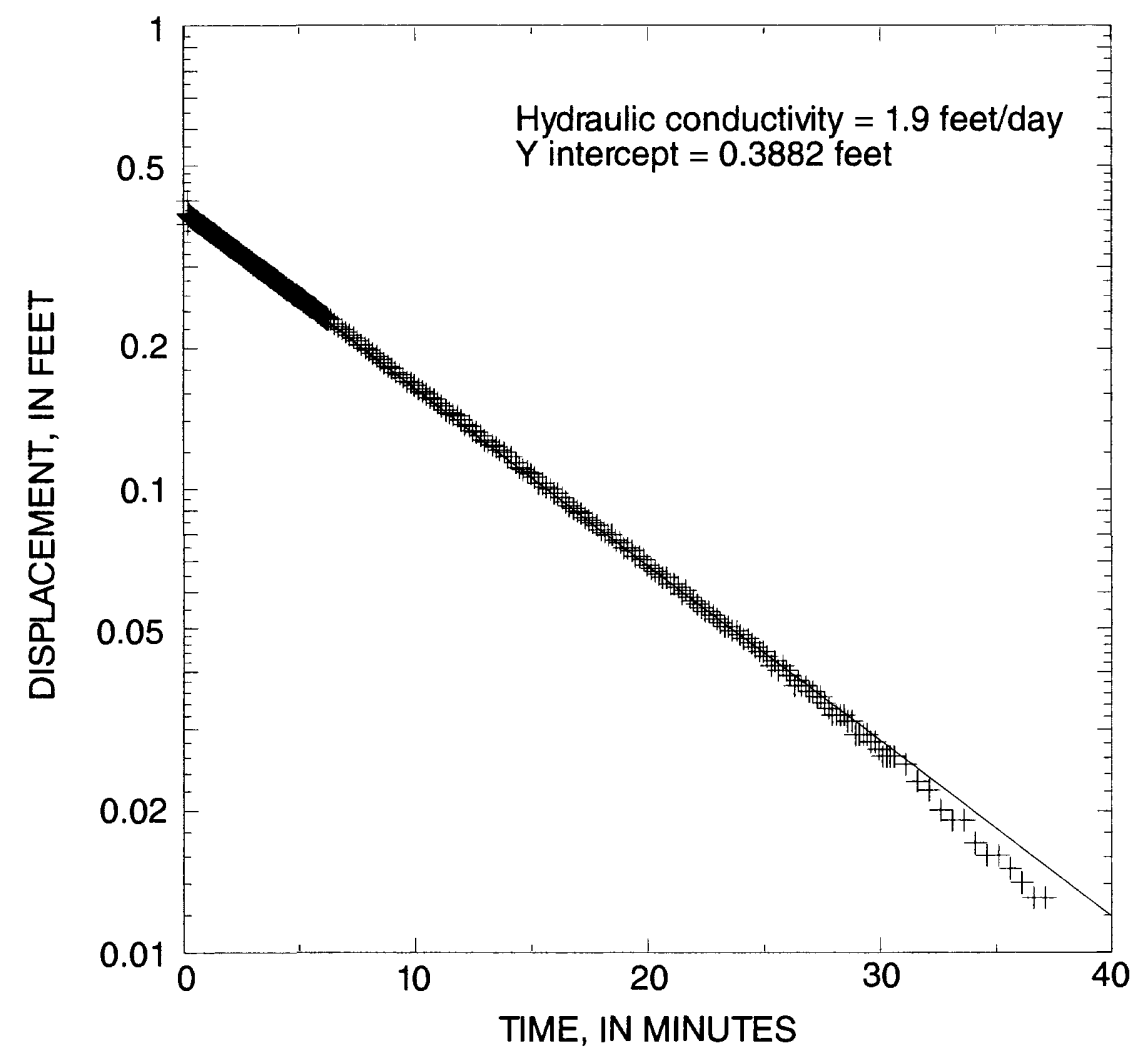

(B)

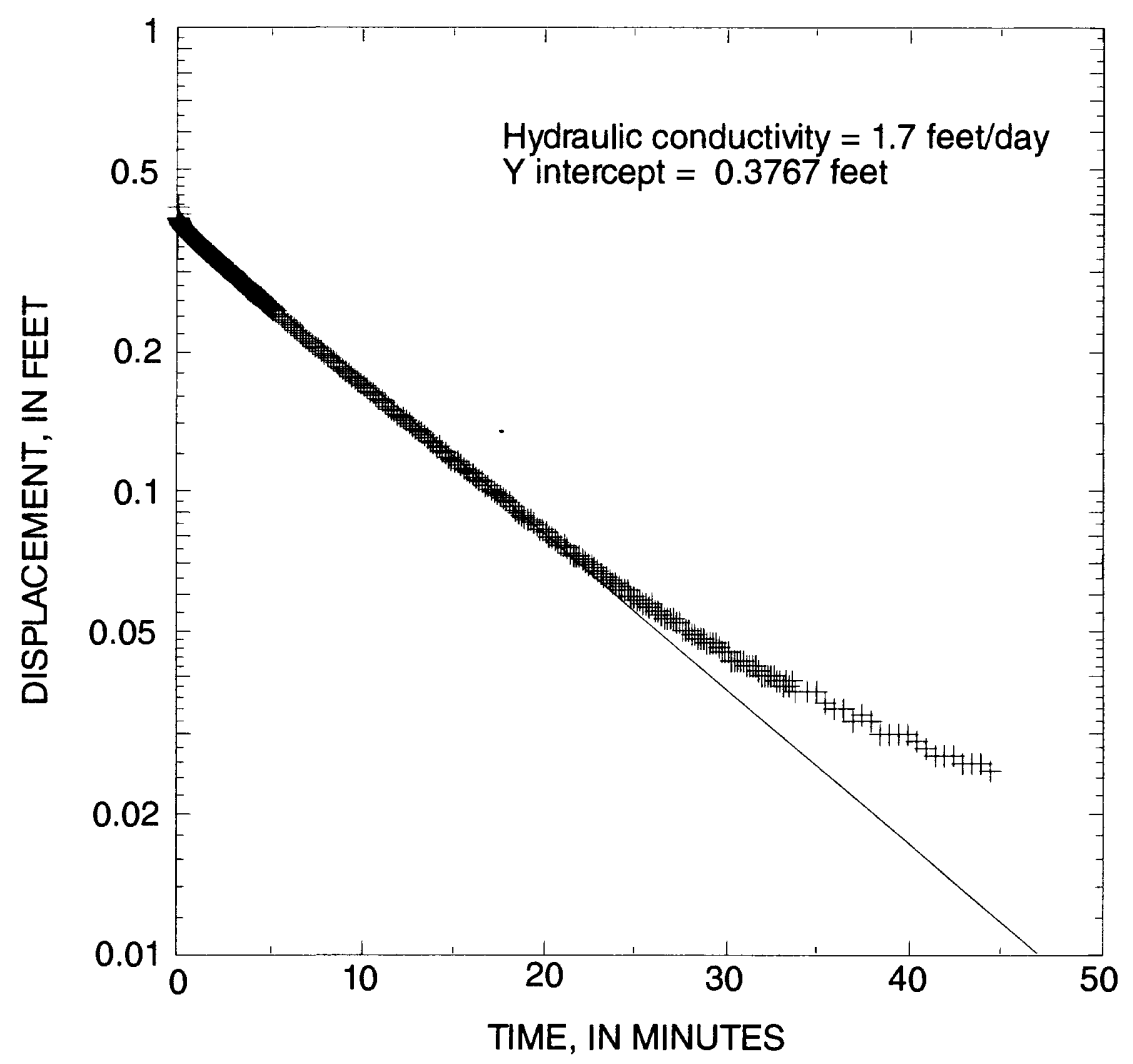

Appendix 8. Plots of slug test data response at $\operatorname{KW} 2 \mathrm{D}(A)$ forward, and $(B)$ reverse, Milford, New Hampshire-Continued. 
(A)

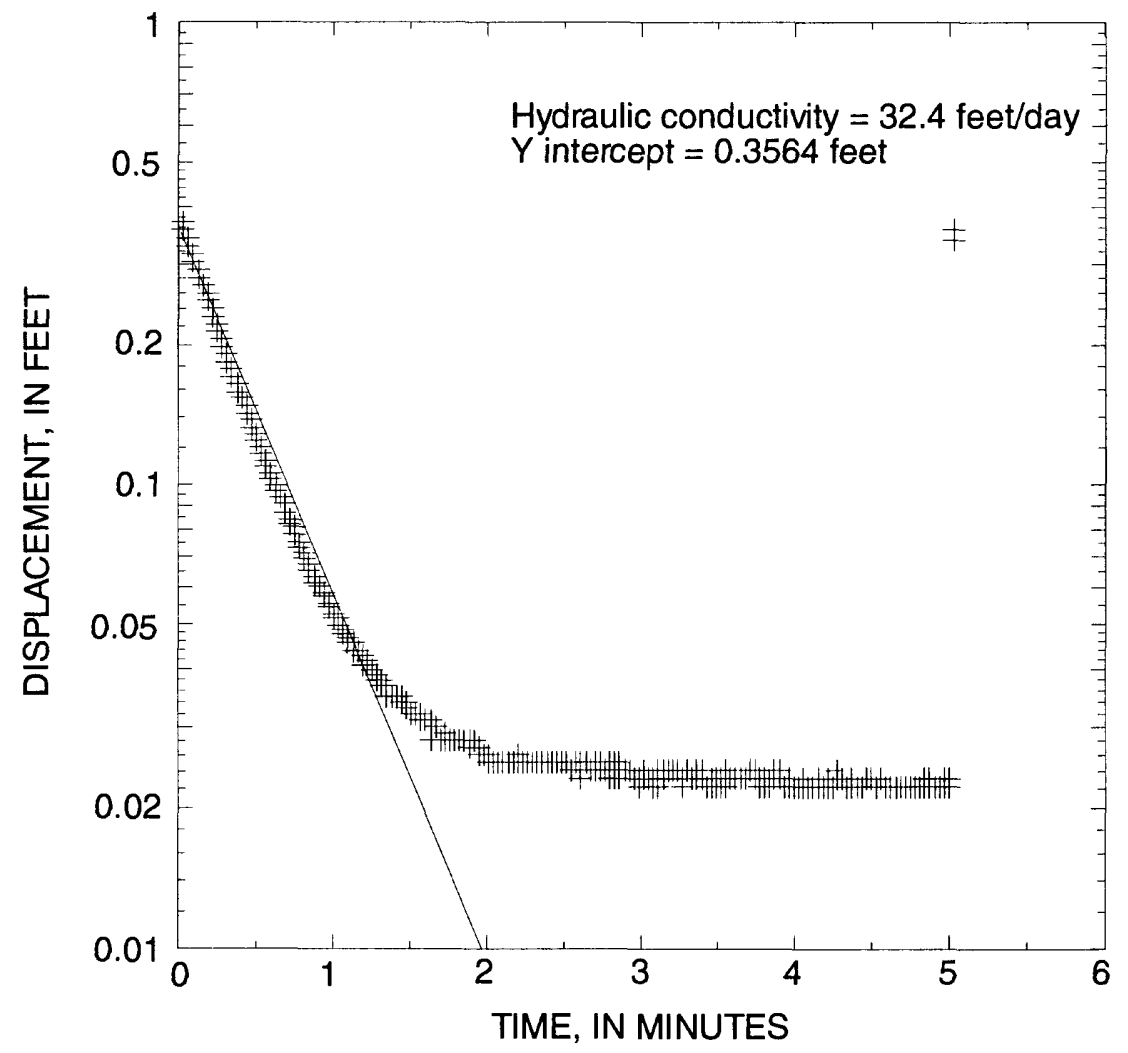

(B)

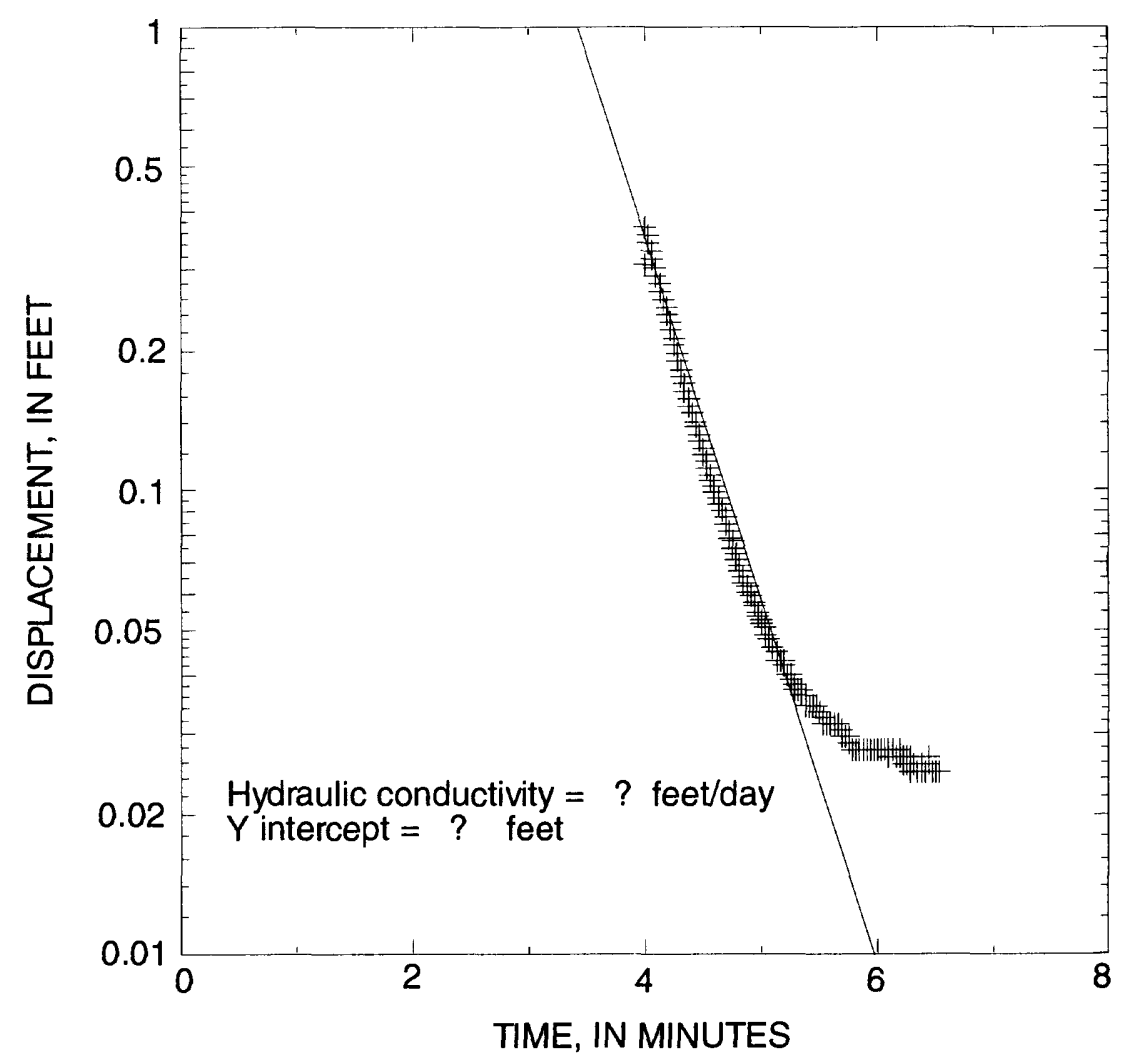

Appendix 8. Plots of slug test data response at KW2S $(A)$ forward, and (B) reverse, Milford, New Hampshire-Continued. 
(A)

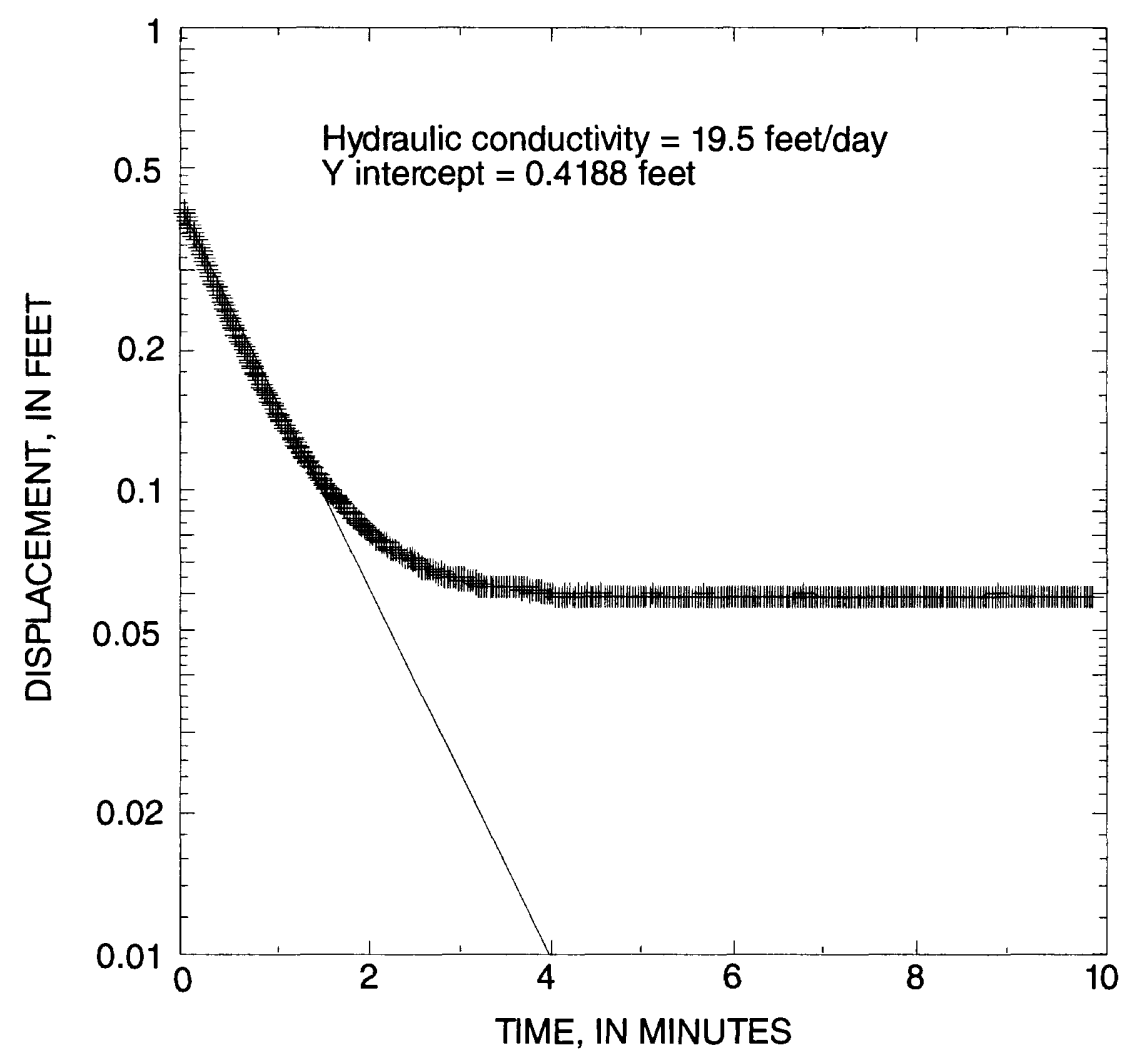

(B)

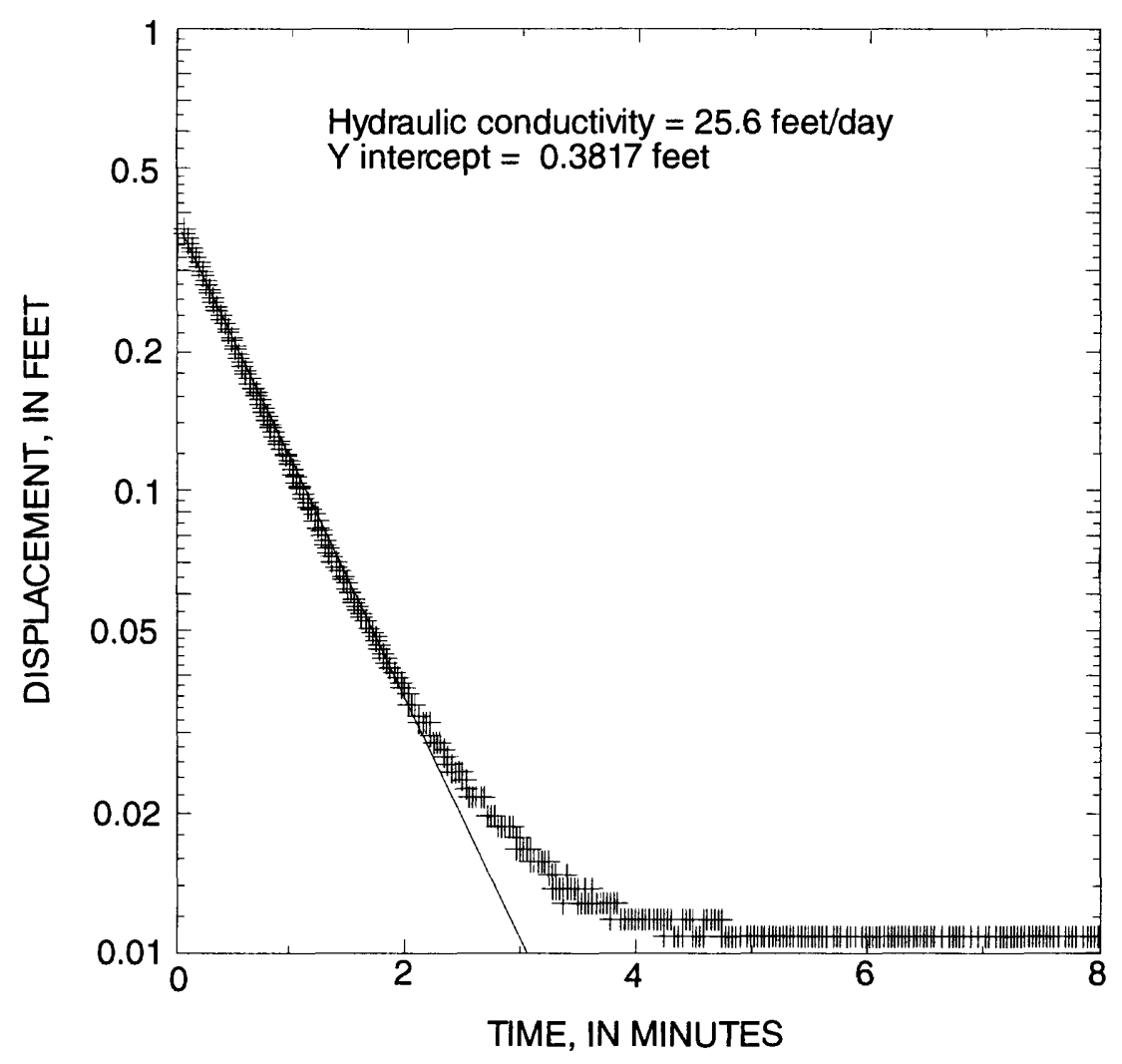

Appendix 8. Plots of slug test data response at KW3D $(A)$ forward, and $(B)$ reverse, Milford, New Hampshire-Continued. 
(A)

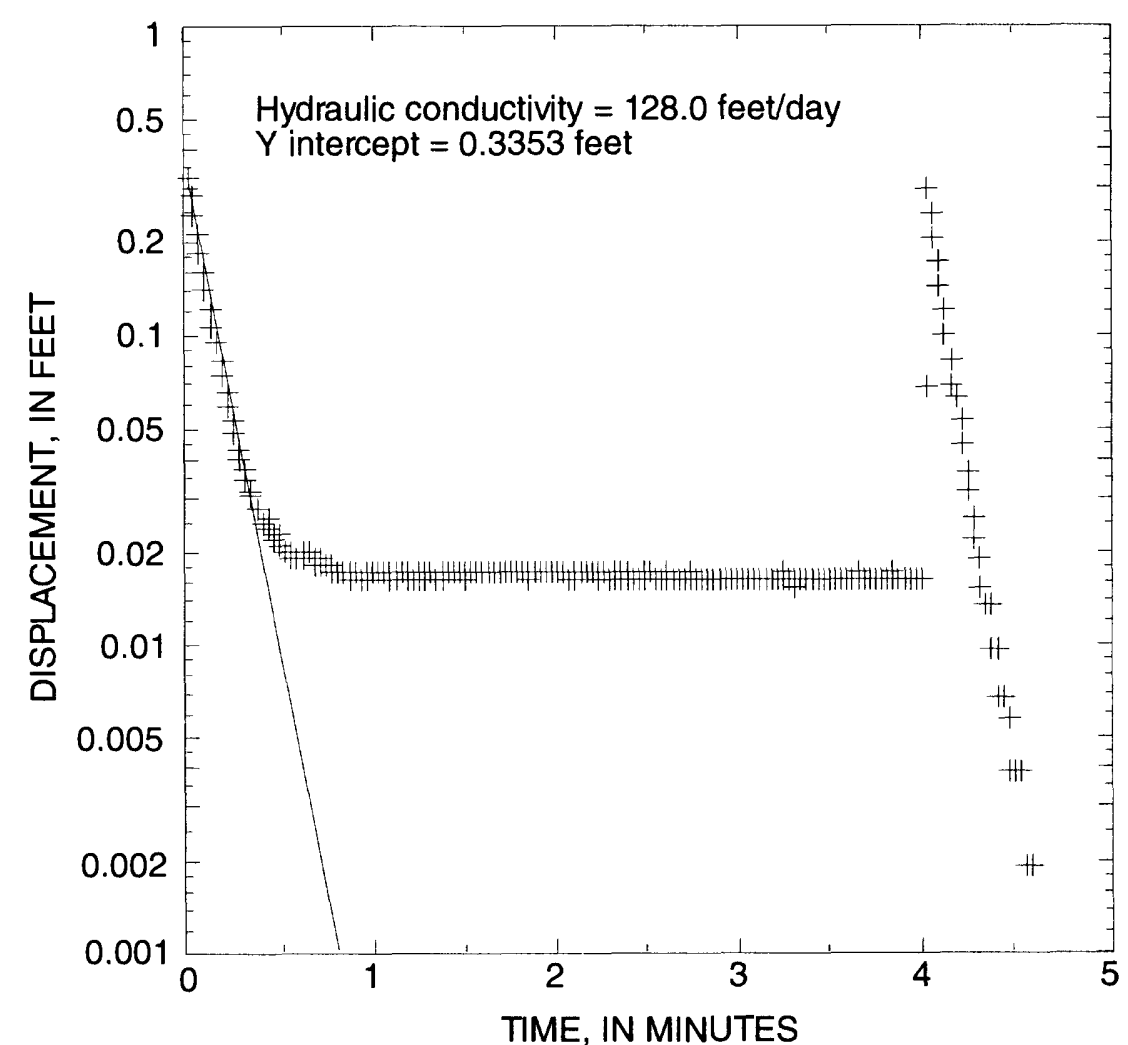

(B)

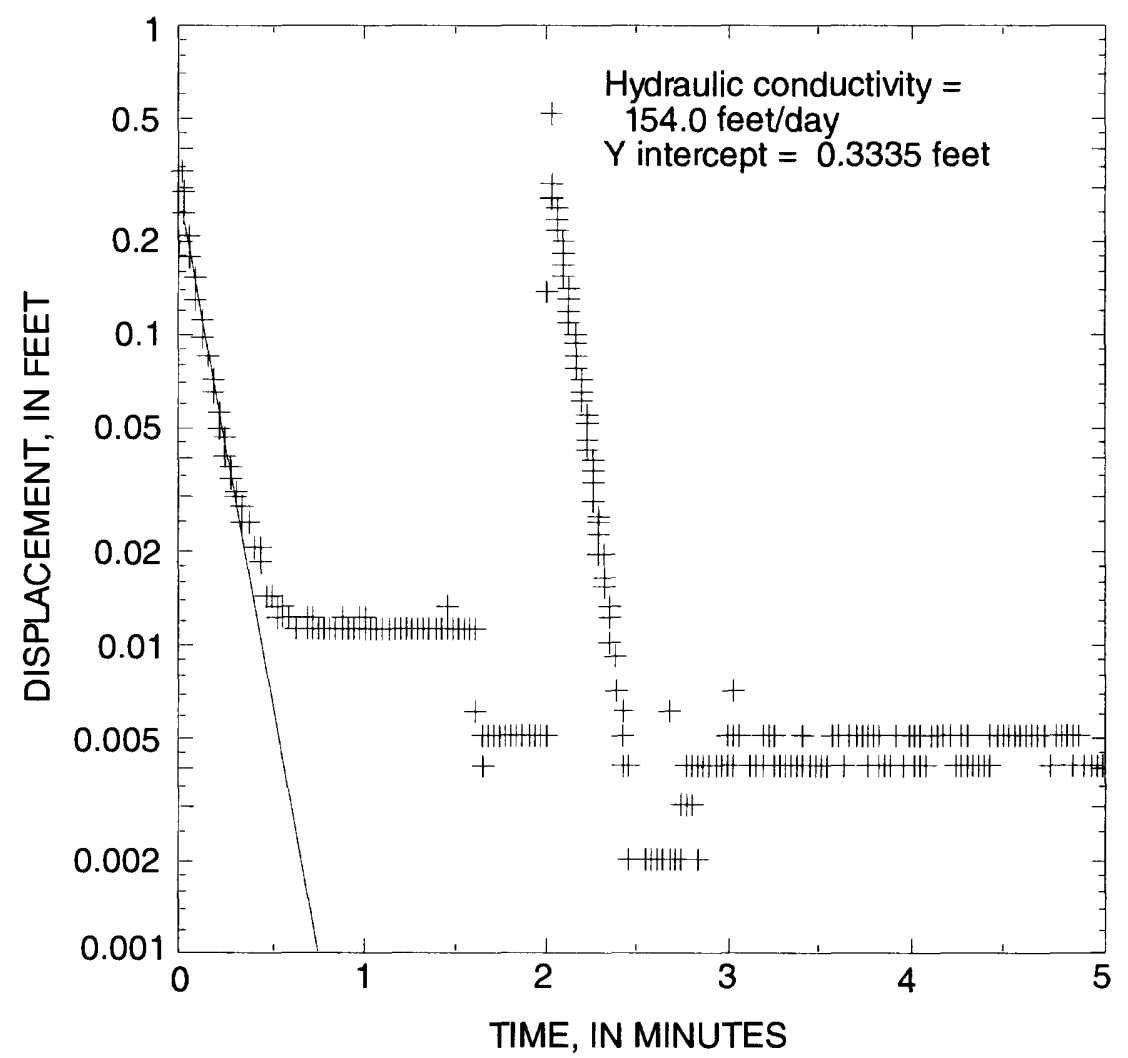

Appendix 8. Plots of slug test data response at $\operatorname{KW} 3 S(A)$ forward, and $(B)$ reverse, Milford, New Hampshire-Continued. 
(A)

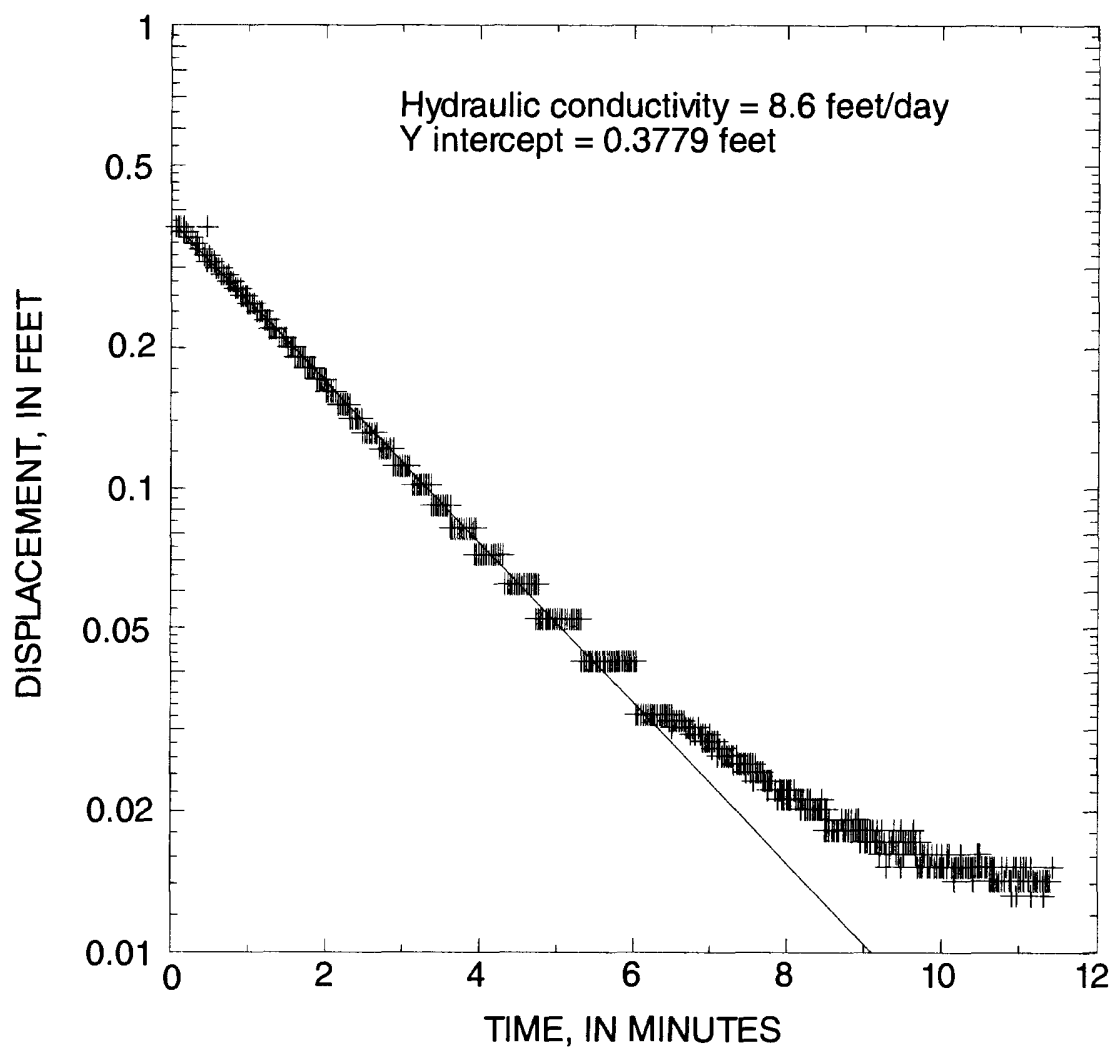

(B)

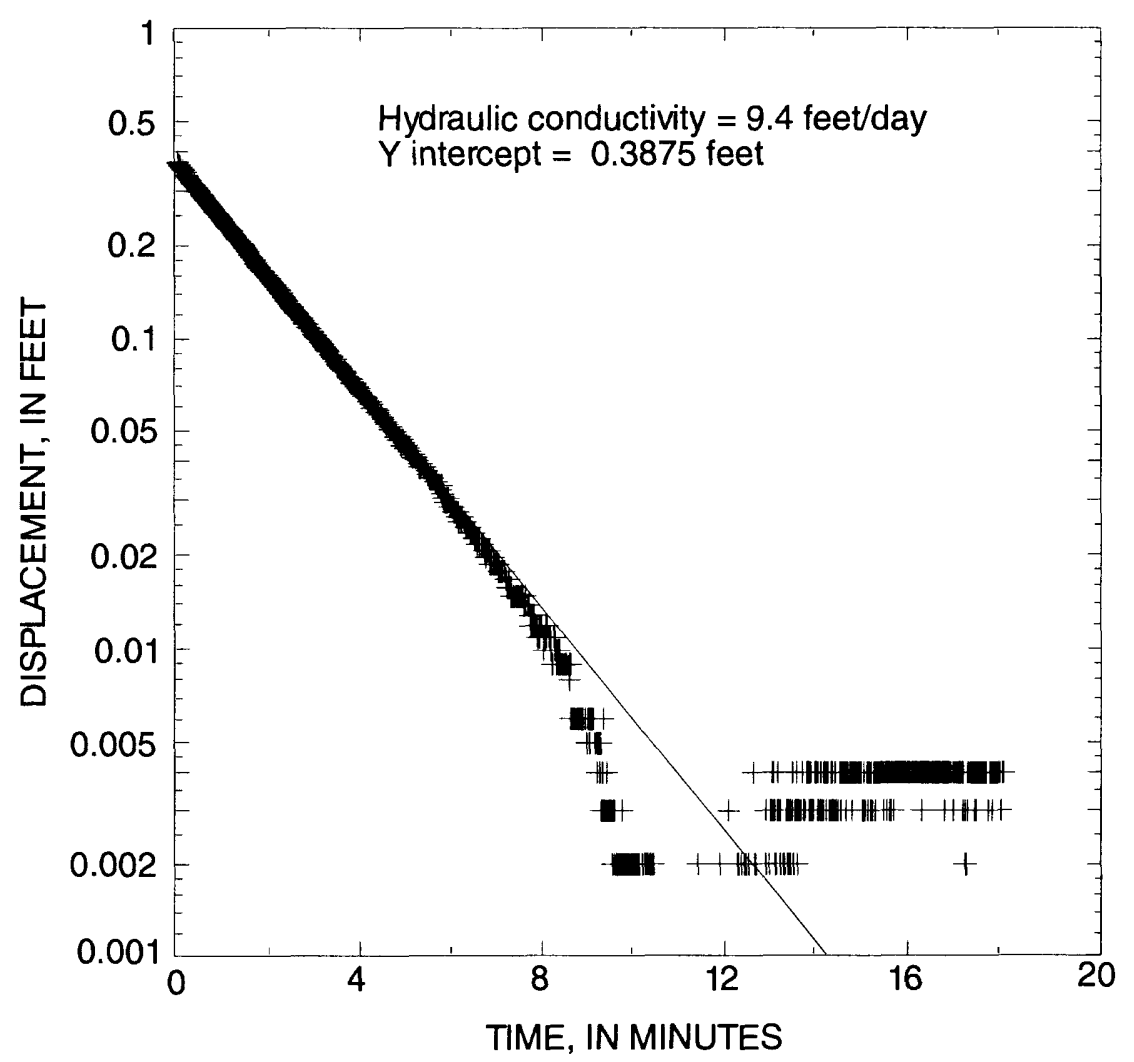

Appendix 8. Plots of slug test data response at $\operatorname{KW4D~}(A)$ forward, and $(B)$ reverse, Milford, New Hampshire-Continued. 
(A)

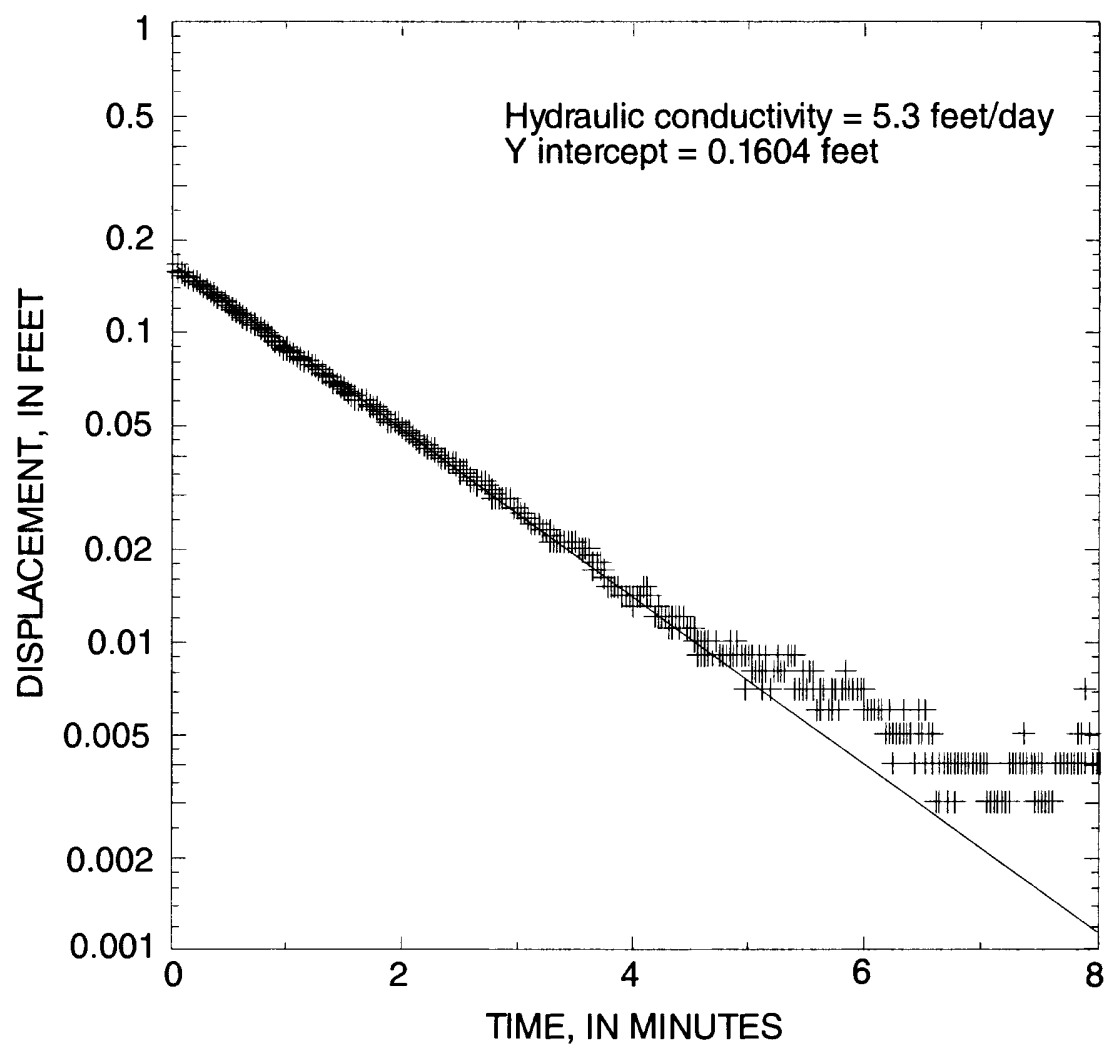

(B)

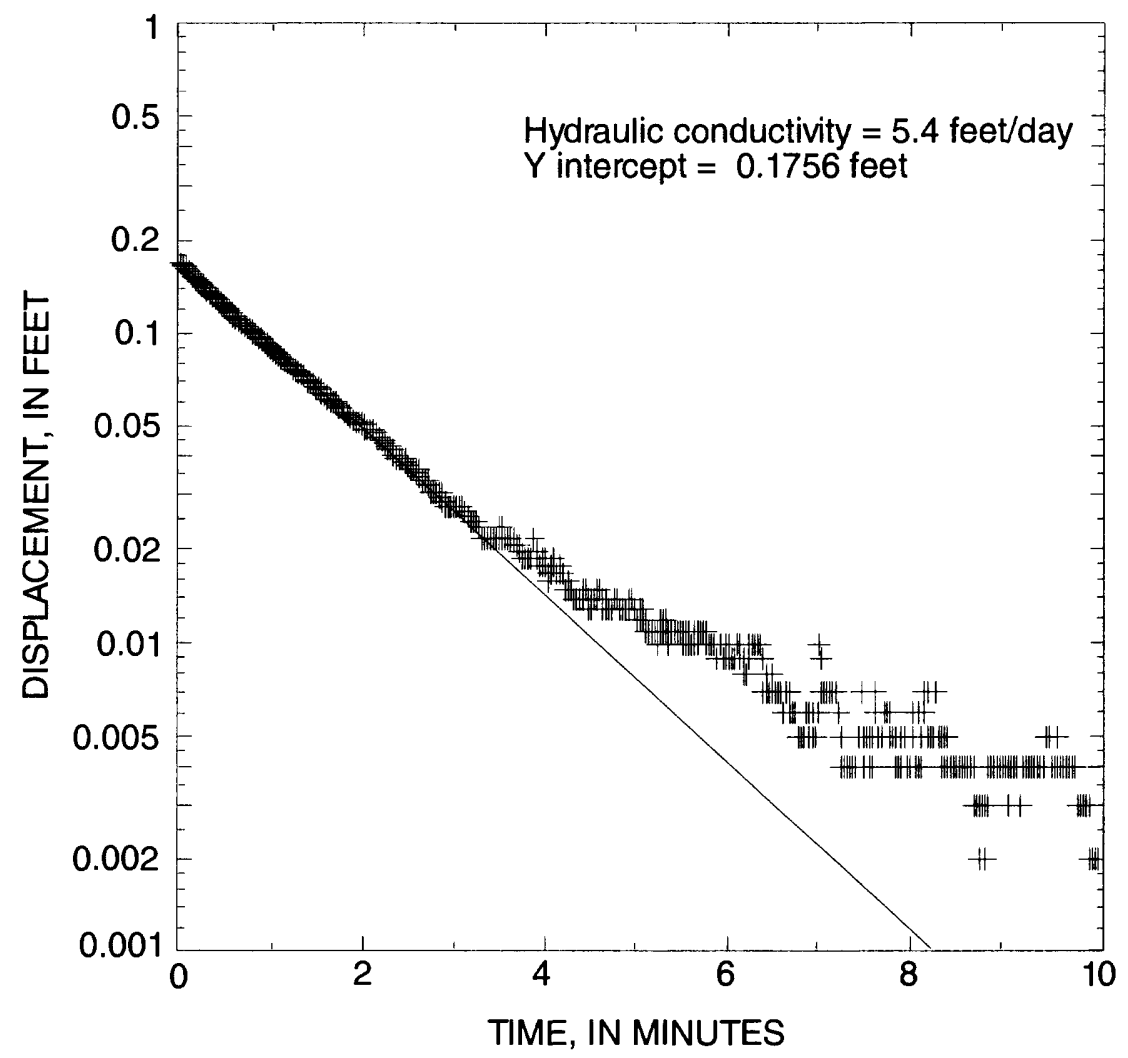

Appendix 8. Plots of slug test data response at KW4S $(A)$ forward, and $(B)$ reverse, Milford, New Hampshire-Continued. 
(A)

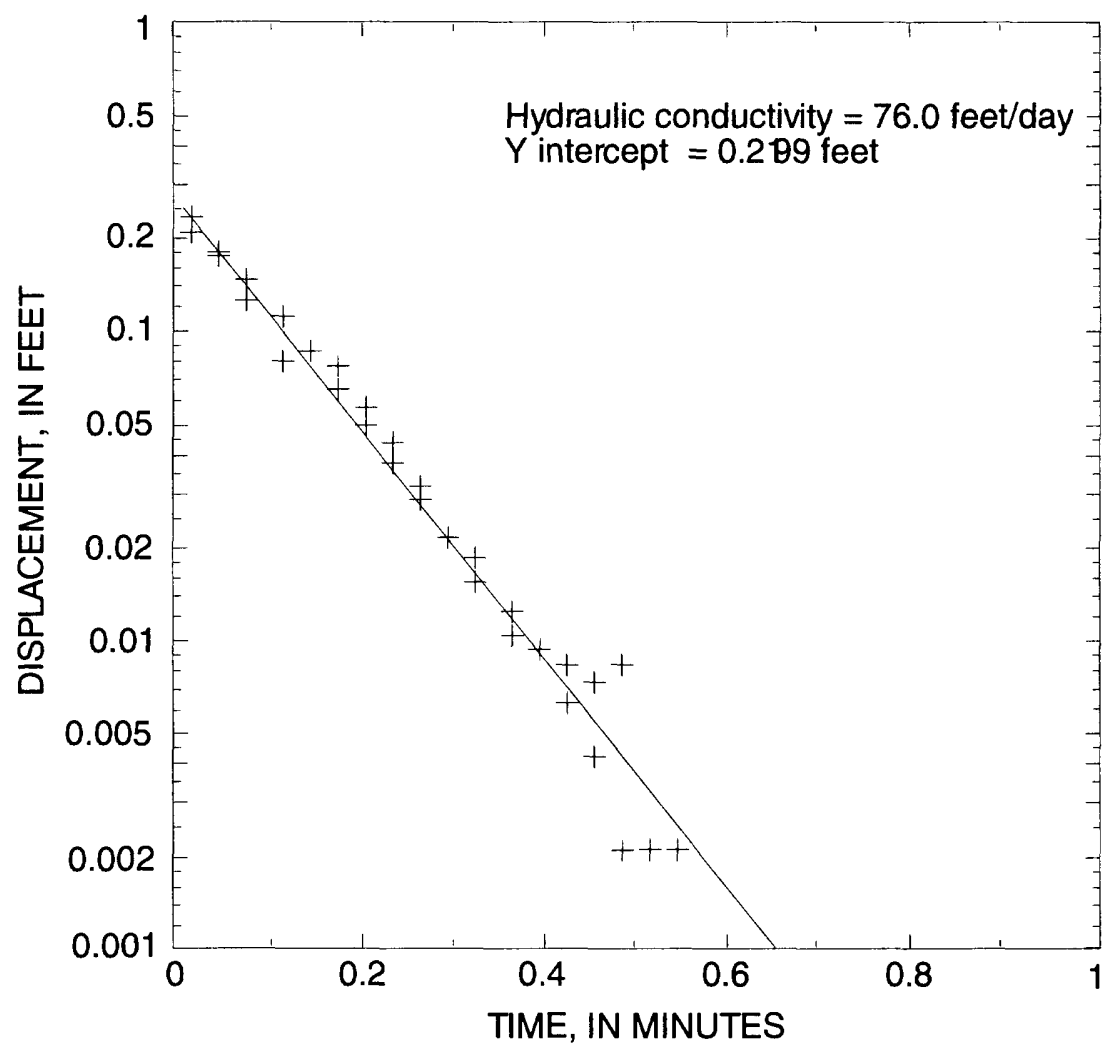

(B)

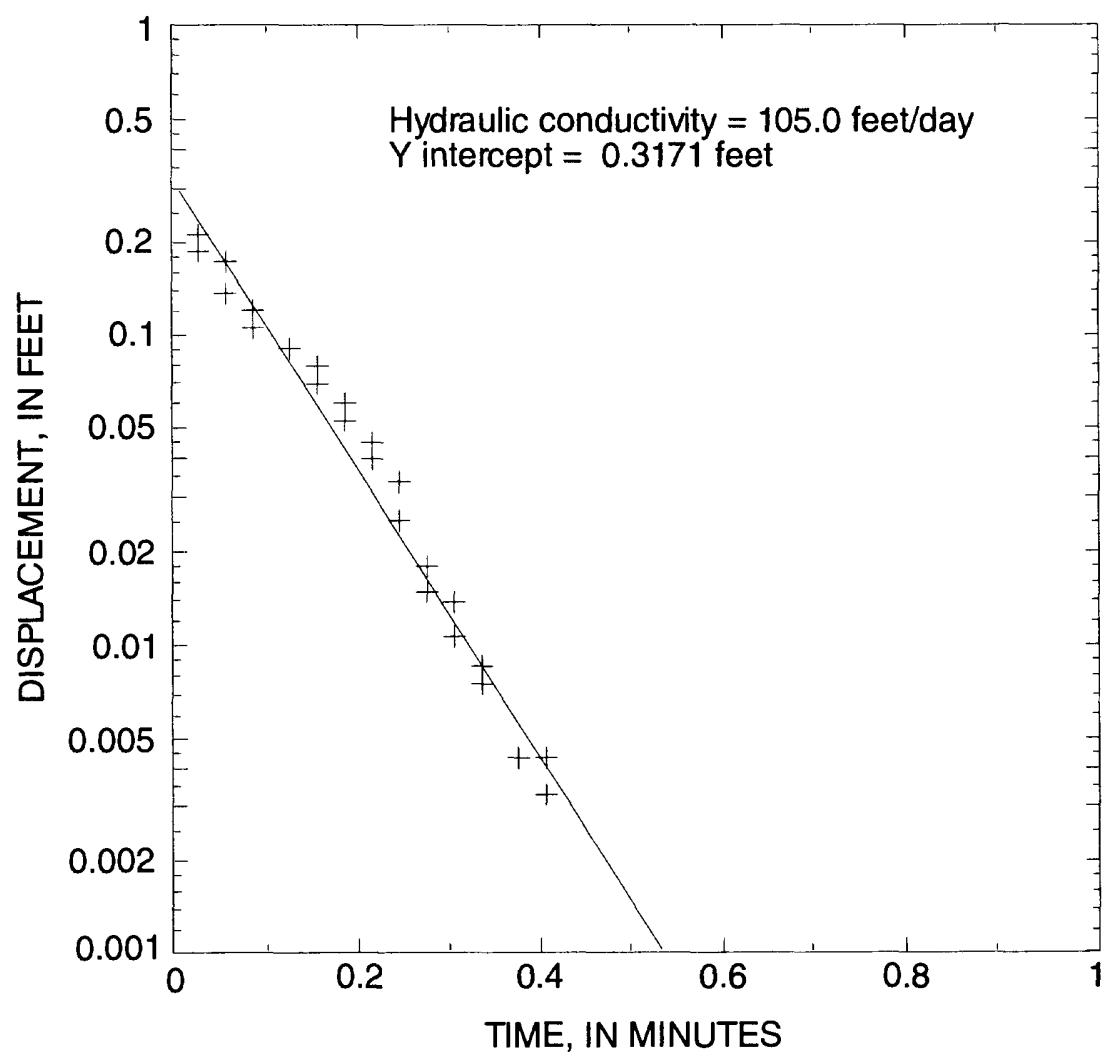

Appendix 8. Plots of slug test data response at OW3 $(A)$ forward, and $(B)$ reverse, Milford, New Hampshire-Continued. 
APPENDIX 9. Information used for analysis of multiple-well aquifer test, Milford, New Hampshire 
Appendix 9. Information used for analysis of multiple-well aquifer test, Milford, New Hampshire

[Type curve match points: $u$ and $\mathrm{W}(u)$ both equal to 1 , ratio of storage to specific yield of 0.001 , and a ratio of vertical to horizontal hydraulic conductivity of 0.1 . Withdrawal rate was $40.2 \mathrm{ft}^{3} / \mathrm{d}$; , indicates approximation; --, indicates poor data not shown]

\begin{tabular}{|c|c|c|c|c|c|c|c|}
\hline \multirow{3}{*}{$\begin{array}{l}\text { Observation } \\
\text { well }\end{array}$} & \multirow{3}{*}{$\begin{array}{c}\text { Radial } \\
\text { distance } \\
\text { from } \\
\text { Keyes } \\
\text { well }(r) \\
\text { (ft) }\end{array}$} & \multirow{3}{*}{$\begin{array}{c}\text { Saturated } \\
\text { thickness } \\
(b) \\
\text { (ft) }\end{array}$} & \multirow{3}{*}{$\begin{array}{l}\text { Height above } \\
\text { base of the } \\
\text { aquifer to } \\
\text { middle of well } \\
\text { screen divided } \\
\text { by } b\end{array}$} & \multicolumn{4}{|c|}{ Type curve match points } \\
\hline & & & & \multicolumn{2}{|c|}{ Early time $(t)$} & \multicolumn{2}{|c|}{ Late time } \\
\hline & & & & $\begin{array}{c}t r^{2} \\
(\mathrm{~min} / \mathrm{ft})\end{array}$ & $\begin{array}{l}\text { Draw- } \\
\text { down } \\
\text { (ft) }\end{array}$ & $\begin{array}{c}t r^{2} \\
(\mathrm{~m} / \mathrm{n} / \mathrm{ft})\end{array}$ & $\begin{array}{c}\text { Draw- } \\
\text { down } \\
\text { (ft) }\end{array}$ \\
\hline KW2s & 236 & 66 & 0.87 & 0.0005 & 0.9 & 0.0006 & 1.2 \\
\hline KW2d & 237 & 66 & .32 & .001 & 4.5 & .002 & 8.8 \\
\hline KW3s & 259 & 68 & .86 & .0006 & .6 & .00004 & .45 \\
\hline KW3d & 251 & 68 & .42 & .0006 & 3.9 & .001 & 4.8 \\
\hline KW4s & 237 & $\sim 56$ & .85 & .0007 & 7.2 & .0002 & 7.0 \\
\hline KW4d & 237 & $\sim 56$ & .19 & .0007 & 8.1 & .002 & 8.5 \\
\hline PW1s & 176 & 64 & .99 & .0008 & 2.5 & .0008 & 2.0 \\
\hline PW1d & 176 & 64 & .38 & .0016 & 6.6 & .001 & 5.1 \\
\hline PW2s & 208 & 61 & .98 & -- & -- & .006 & 1.5 \\
\hline PW2d & 208 & 61 & .31 & .001 & 10.1 & .002 & 10.0 \\
\hline PW3s & 276 & 64 & .98 & -- & -- & .0005 & 1.8 \\
\hline PW3d & 276 & 64 & .23 & .002 & 10.2 & .002 & 9.6 \\
\hline
\end{tabular}



APPENDIX 10. Information used for analysis of
slug tests, Milford, New Hampshire 
Appendix 10. Information used for analysis of slug tests, Milford, New Hampshire

[Well and casing radius are 0.083 foot, except for OW3 which is 0.18 foot.; $\sim$, indicates approximation]

\begin{tabular}{|c|c|c|c|c|c|c|c|c|}
\hline Well & Test & $\begin{array}{c}\text { Displace- } \\
\text { ment } \\
\text { (feet) }\end{array}$ & $\begin{array}{l}\text { Length of } \\
\text { open } \\
\text { interval } \\
\text { (feet) }\end{array}$ & $\begin{array}{l}\text { Height of } \\
\text { static } \\
\text { column } \\
\text { (feet) }\end{array}$ & $\begin{array}{c}\text { Saturated } \\
\text { thickness } \\
\text { (feet) }\end{array}$ & $\begin{array}{l}\text { Displace- } \\
\text { ment at } \\
\text { specified } \\
\text { time } \\
\text { (feet) }\end{array}$ & $\begin{array}{c}\text { Time } \\
\text { at specified } \\
\text { displace- } \\
\text { ment } \\
\text { (minutes) }\end{array}$ & $\begin{array}{l}\text { Computed } \\
\text { hydraulic- } \\
\text { conduc- } \\
\text { tivity } \\
\text { (feet per } \\
\text { day) }\end{array}$ \\
\hline KW1 & Forward & 0.52 & 2.0 & 46 & 73 & 0.2 & 4.4 & 4.6 \\
\hline KW2s & Forward & .36 & 2.0 & 9 & 66 & .2 & .6 & 32.4 \\
\hline \multirow[t]{2}{*}{$\mathrm{KW} 2 \mathrm{~d}$} & Forward & .39 & 2.0 & 46 & 66 & .2 & 7.4 & 1.9 \\
\hline & Reverse & .38 & 2.0 & 46 & 66 & .2 & 9 & 1.7 \\
\hline \multirow[t]{2}{*}{ KW3d } & Forward & .42 & 2.0 & 41 & 68 & .2 & .8 & 19.5 \\
\hline & Reverse & .38 & 2.0 & 41 & 68 & .2 & .75 & 25.6 \\
\hline \multirow[t]{2}{*}{$\mathrm{KW} 4 \mathrm{~s}$} & Forward & .16 & 2.0 & 10.7 & $\sim 56$ & .05 & 2.0 & 5.3 \\
\hline & Reverse & .18 & 2.0 & 10.7 & -56 & .04 & 2.35 & 5.4 \\
\hline \multirow[t]{2}{*}{ KW4d } & Forward & .38 & 2.0 & 46 & $\sim 56$ & .1 & 3.05 & 8.6 \\
\hline & Reverse & .39 & 2.0 & 46 & $\sim 56$ & .03 & 6.45 & 9.4 \\
\hline OW3 & Forward & .22 & 3.0 & 36.5 & $\sim 40$ & .01 & .36 & 76 \\
\hline
\end{tabular}

